DANIEL FERNANDES BORRELLY

\title{
ESTUDO COMPARATIVO DA DEGRADAÇÃO DE POLIESTIRENO E DE POLIESTIRENO DE ALTO IMPACTO POR ENVELHECIMENTOS NATURAL E ARTIFICIAL
}

\author{
Dissertação apresentada à Escola \\ Politécnica da Universidade de \\ São Paulo para obtenção do \\ Título de Mestre em Engenharia
}

São Paulo

2002 
DANIEL FERNANDES BORRELLY

\section{ESTUDO COMPARATIVO DA DEGRADAÇÃO DE POLIESTIRENO E DE POLIESTIRENO DE ALTO IMPACTO POR ENVELHECIMENTOS NATURAL E ARTIFICIAL}

Dissertação apresentada à Escola Politécnica da Universidade de São Paulo para obtenção do

Título de Mestre em Engenharia

Área de Concentração:

Engenharia Química

Orientador:

Prof. Dr. Hélio Wiebeck

São Paulo 
À Fernanda, minha querida esposa, com amor

A todas as medidas de proteção à camada de ozônio 


\section{AGRADECIMENTOS}

Ao amigo e orientador Prof. Dr. Hélio Wiebeck pela orientação e incentivo.

Ao Júlio Harada pelo tema, sugestões e visitas.

À BASF S.A. por ceder as amostras de poliestireno.

Aos Profs. Luci Diva Brocardo Machado e Leonardo G. Andrade e Silva (IPEN), Selma Barbosa Jaconis e Armênio Gomes Pinto (IPT) pelos laboratórios, equipamentos, discussões e ajuda.

Ao técnico Luiz Carlos do Carmo Lindo (IPT) pelas grandes idéias e, juntamente com Renato dos Santos (IPT) e Djalma Batista Dias (IPEN), pela ajuda nos ensaios.

À Maria Lúcia Adamo Attar e Maria Apparecida Silva por tornar as revisões mais agradáveis.

Aos Profs. Célio Xavier, Antonio Carlos Vieira Coelho e Francisco Rolando Valenzuela Díaz pelas sugestões de melhorias que engrandeceram este trabalho. 


\section{SUMÁRIO}

Lista de Figuras

Lista de Tabelas

Lista de Abreviaturas e Siglas

Lista de Símbolos

Resumo

Abstract

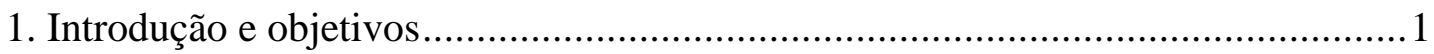

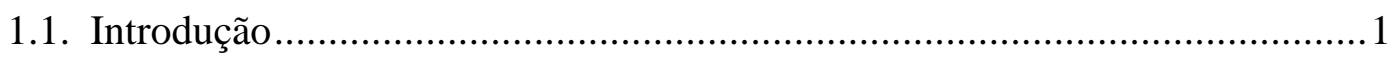

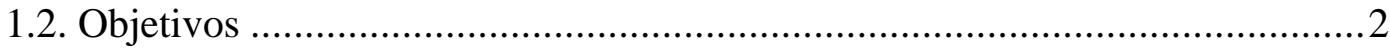

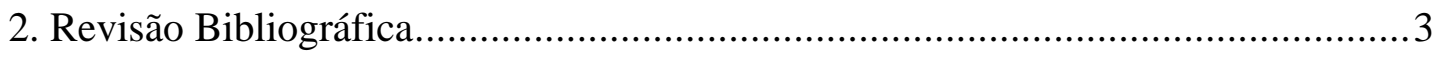

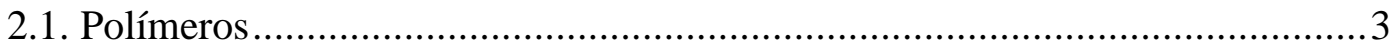

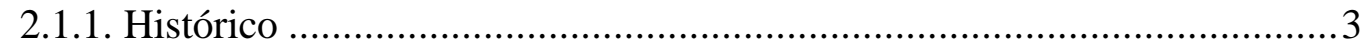

2.1.2. Propriedades dos Plásticos - Aditivos.................................................. 4

2.1.2.1. Antiestáticos .......................................................................... 4

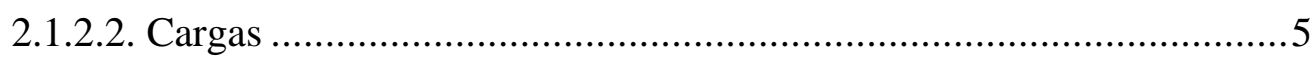

2.1.2.3. Agentes de Acoplamento ...........................................................5

2.1.2.4. Retardantes de Chama .................................................................5

2.1.2.5. Agentes de processamento / Lubrificantes .....................................6

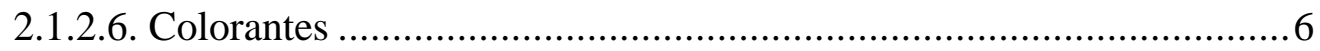

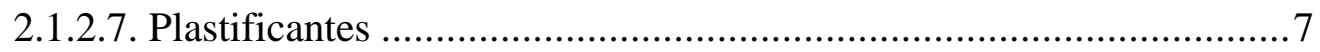

2.1.2.8. Reforçadores ........................................................................ 7

2.1.2.9. Estabilizantes.................................................................... 7

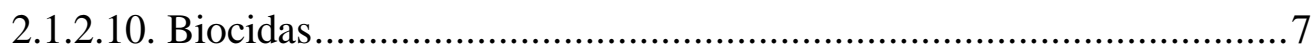

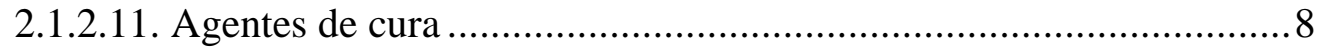

2.1.2.12. Modificadores de impacto e de distorção térmica ............................8

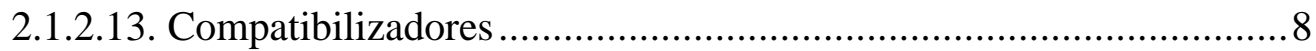

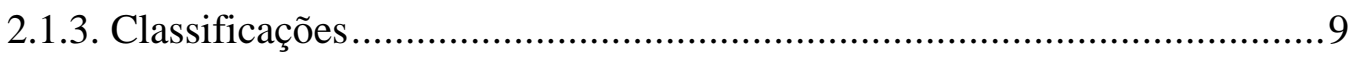

2.1.3.1. Termoplásticos, termofixos e elastômeros....................................... 9

2.1.3.1.1. Termoplásticos................................................................. 9

2.1.3.1.2. Termofixos .................................................................... 9 
2.1.3.1.3. Elastômeros

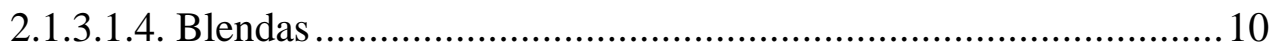

2.1.3.2. Mecanismo de polimerização, segundo Wallace Carothers: ............10

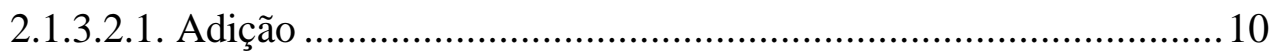

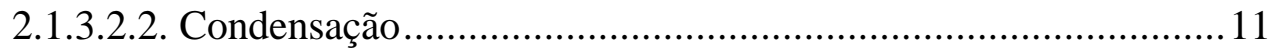

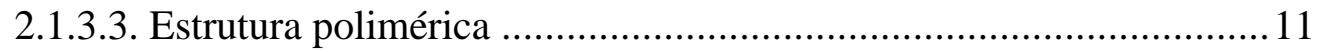

2.1.3.4. Homopolímeros e copolímeros ......................................................11

2.1.3.5. Taticidade (isômeros) .................................................................. 11

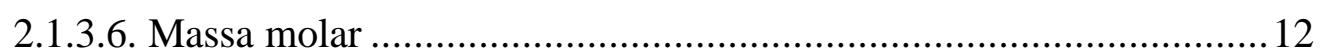

2.1.3.6.1. Distribuiçãa molecular ..................................................... 12

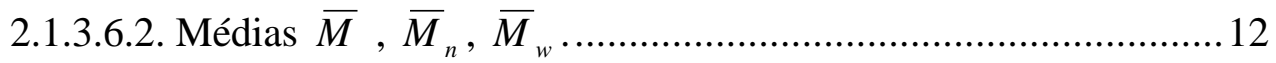

2.1.3.7. Morfologia e transições térmicas .................................................... 13

2.1.3.7.1. Polímeros Amorfos ...................................................................... 13

2.1.3.7.2. Temperatura de transição vítrea .............................................. 13

2.1.3.7.3. Polímeros cristalinos.............................................................. 13

2.1.3.7.4. Temperatura de fusão cristalina........................................... 14

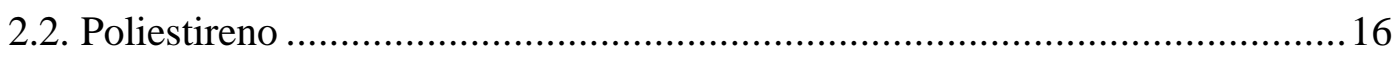

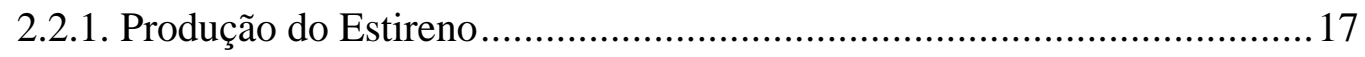

2.2.2. Polimerização do estireno ............................................................... 17

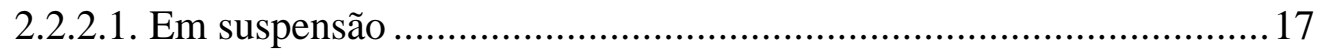

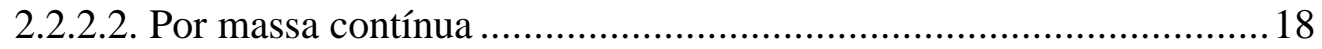

2.2.3. Tipos de poliestireno ........................................................................ 18

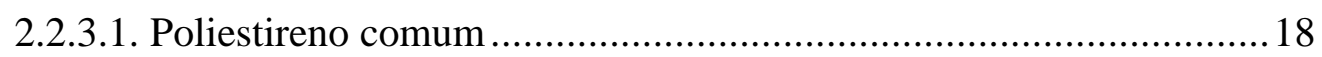

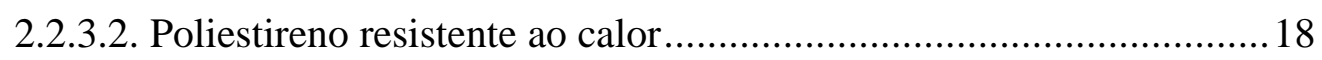

2.2.3.3. Poliestireno resistente ao impacto .................................................. 18

2.2.3.3.1. Mistura mecânica............................................................... 18

2.2.3.3.2. Copolimerização "graft" (por enxerto) .................................... 19

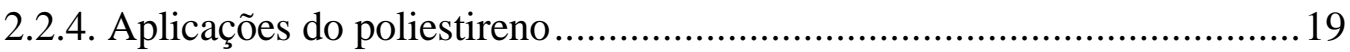

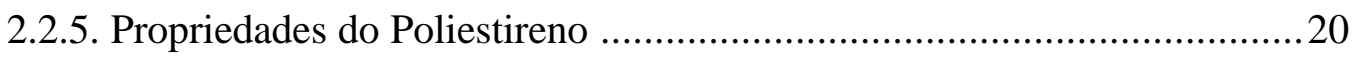

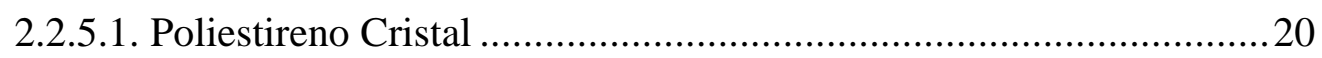

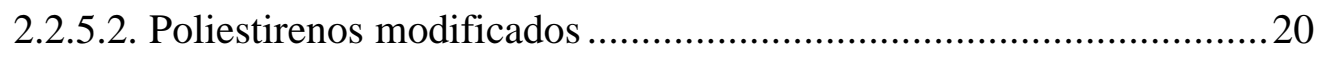

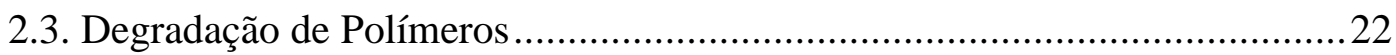




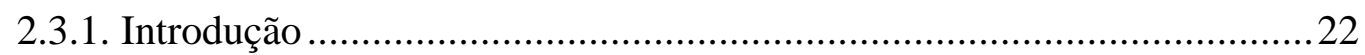

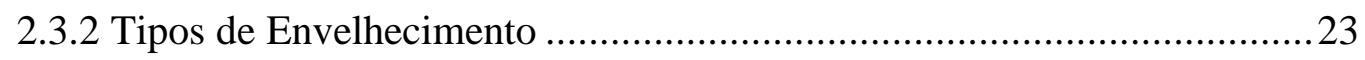

2.3.3. Correlação e Previsão .......................................................................22

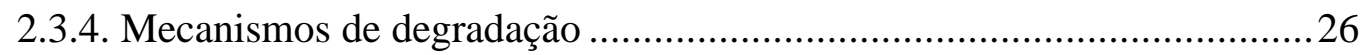

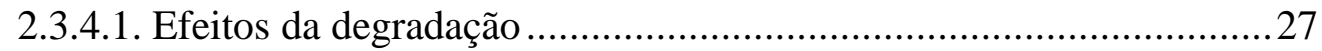

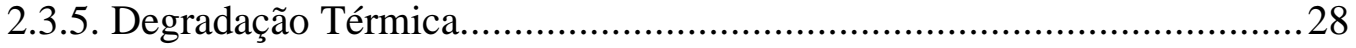

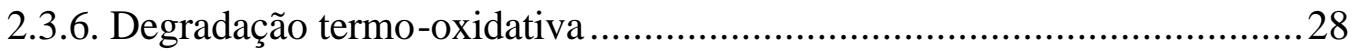

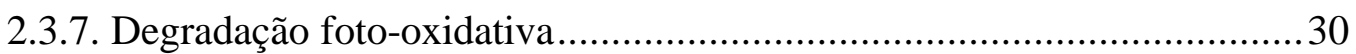

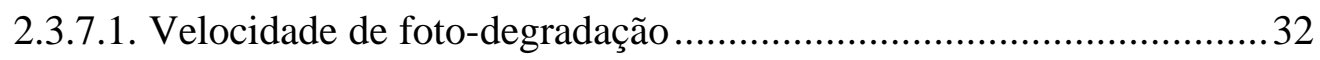

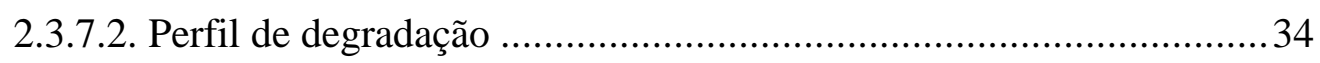

2.3.8. Influência da morfologia na foto-degradação .........................................35

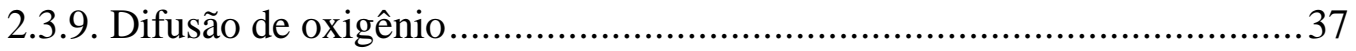

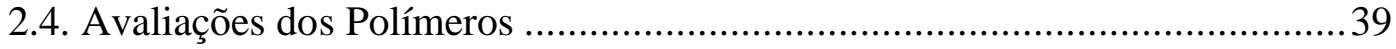

2.4.1. Determinação da estrutura química ....................................................39

2.4.2. Mecanismos de Deformação ............................................................... 40

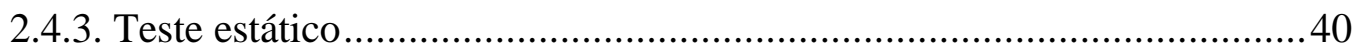

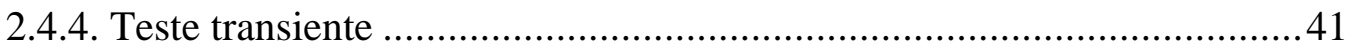

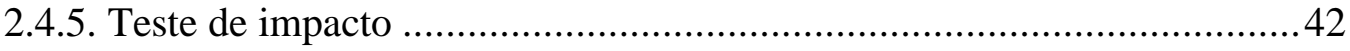

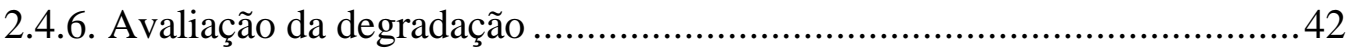

2.4.6.1. Quantificação da degradação química ...........................................43

2.4.6.1.1. Massa molar ............................................................................... 43

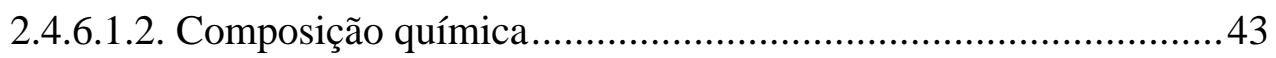

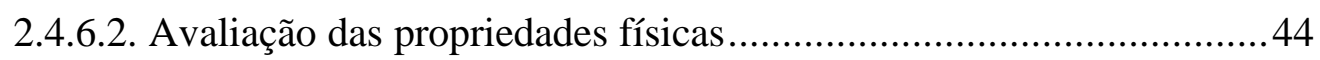

2.4.6.2.1. Comportamento mecânico......................................................44

2.4.6.2.2. Aparência superficial ..........................................................44

2.4.6.2.3. Outras propriedades ......................................................... 45

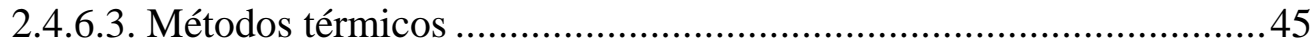

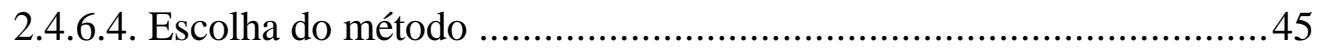

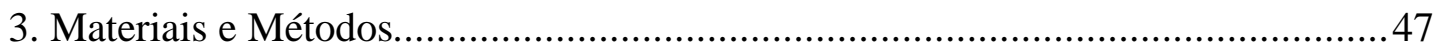

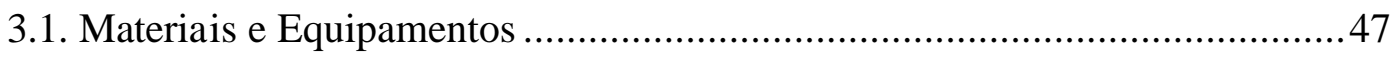

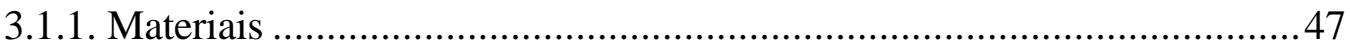

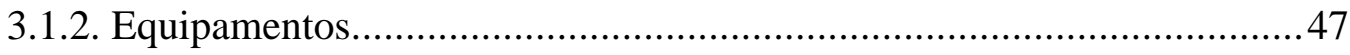


3.1.2.1. Injeção

3.1.2.2. Câmara de Intemperismo Artificial ............................................. 48

3.1.2.3. Estação de Envelhecimento Natural ............................................. 48

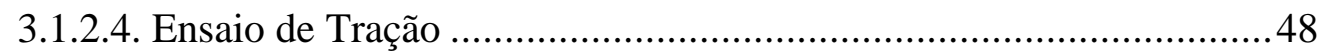

3.1.2.5. Calorimetria Exploratória Diferencial (DSC) ..............................49

3.1.2.6. Resistência ao impacto............................................................... 49

3.1.2.7. Índice de fluidez .................................................................49

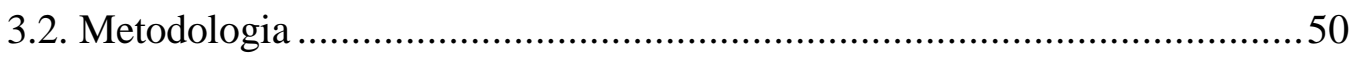

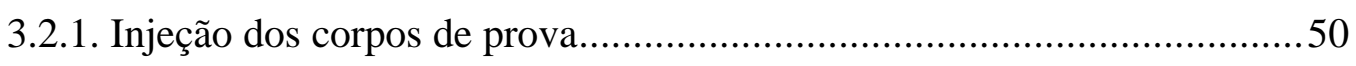

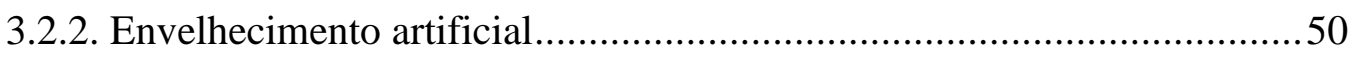

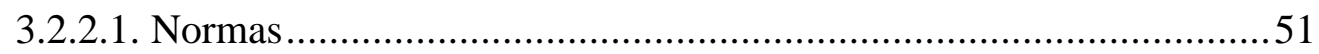

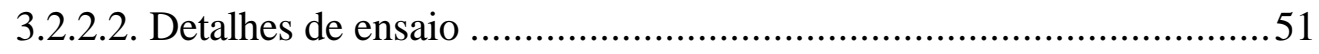

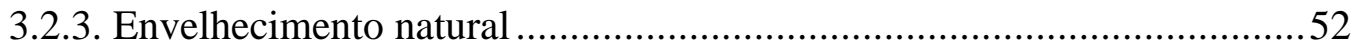

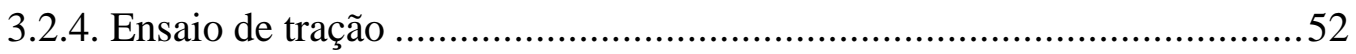

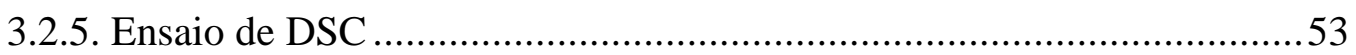

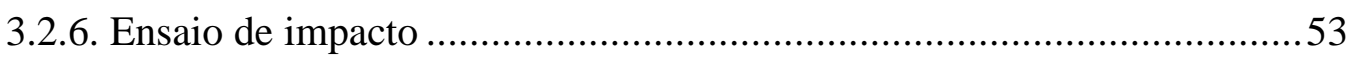

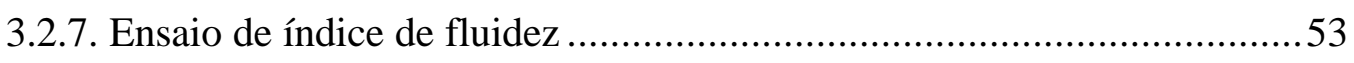

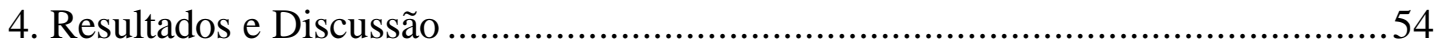

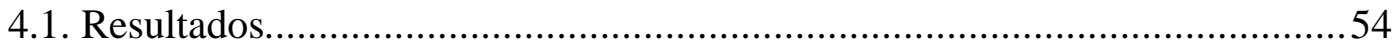

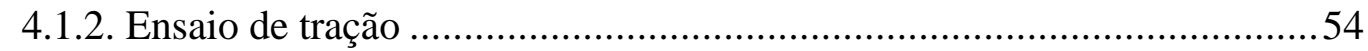

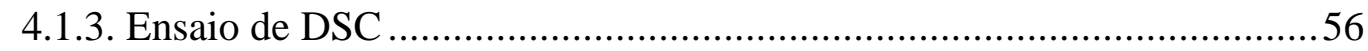

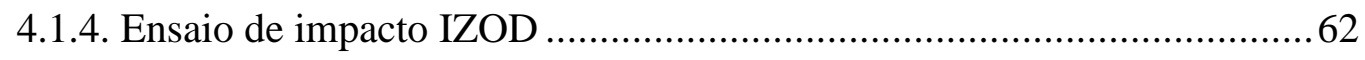

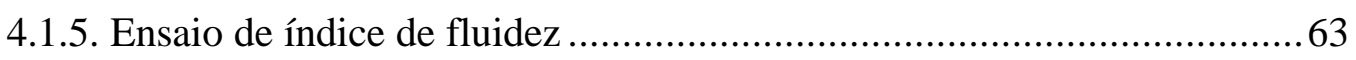

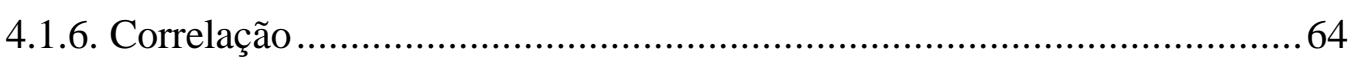

4.1.7. Aparência …………....................................................................... 71

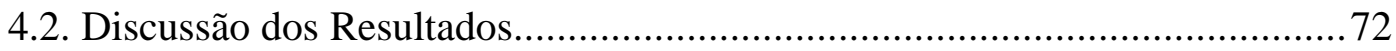

4.2.1. Proposta de correlação........................................................................ 72

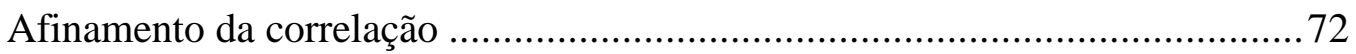

4.2.2. Ensaio de tração ........................................................................... 73

4.2.2. Ensaio de calorimetria exploratória diferencial (DSC) ..........................74

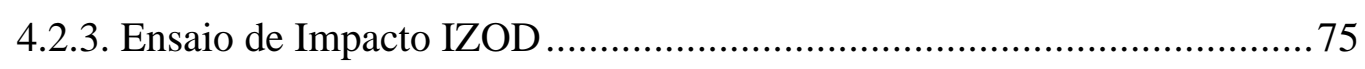

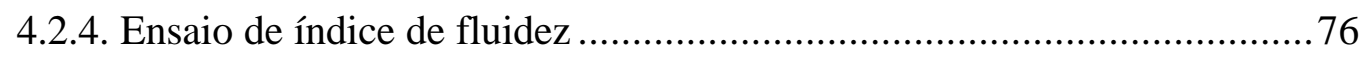




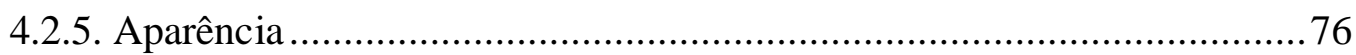

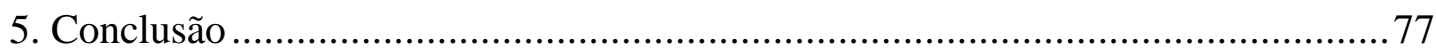

Anexo A - Registro dos ensaios de tração de PS e de PSAI .................................. 79

Anexo B - Registro dos corpos de prova dos ensaios de tração de PS e de PSAI.....83

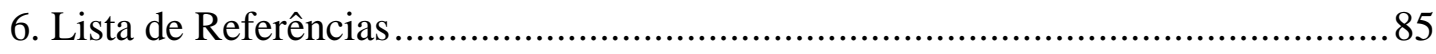




\section{LISTA DE FIGURAS}

Figura 1: Média Molar Numérica em relação à profundidade de corpo de prova de poliestireno, adaptado de O’Donnell; White; Hollding (1994) em escala qualitativa.

Figura 2: Exemplo de curva de ensaio de tração de polímeros, adaptado de Fried (1995).

Figura 3: Curvas do ensaio de DSC do PS em envelhecimento acelerado em 720h com várias amostras

Figura 4: Curvas do ensaio de DSC do PS em envelhecimento acelerado em 1080h com várias amostras

Figura 5: Curvas do ensaio de DSC do PS em envelhecimento natural, $1^{\text {a }}$ corrida...57

Figura 6: Curvas do ensaio de DSC do PS em envelhecimento natural, $2^{\text {a }}$ corrida ...58

Figura 7: Curvas do ensaio de DSC do PS em envelhecimento acelerado, $1^{\mathrm{a}}$ corrida ...

Figura 8: Curvas do ensaio de DSC do PS em envelhecimento acelerado, $2^{\text {a }}$ corrida ...

Figura 9: Curvas do ensaio de DSC do PSAI em envelhecimento natural, $1^{\text {a }}$ corrida ...

Figura 10: Curvas do ensaio de DSC do PSAI em envelhecimento natural, $2^{\text {a }}$ corrida

Figura 11: Curvas do ensaio de DSC do PSAI em envelhecimento acelerado, $1^{\text {a }}$ corrida

Figura 12: Curvas do ensaio de DSC do PSAI em envelhecimento acelerado, $2^{a}$ corrida

Figura 13: Tensão na ruptura em tração de PS de acordo com o envelhecimento. Tempos do envelhecimento artificial estão multiplicados por um fator de aceleração de 4

Figura 14: Elongação na ruptura em tração de PS de acordo com o envelhecimento. Tempos do envelhecimento artificial estão multiplicados por um fator de aceleração de 4 .65 
Figura 15: Tensão na ruptura em tração de PSAI de acordo com o envelhecimento. Tempos do envelhecimento artificial estão multiplicados por um fator de aceleração de 2

Figura 16: Elongação na ruptura em tração de PSAI de acordo com o envelhecimento. Tempos do envelhecimento artificial estão multiplicados por um fator de aceleração de 2 .

Figura 17: Elongação na ruptura em tração de PSAI de acordo com o envelhecimento, sem o ponto inicial. Tempos do envelhecimento artificial estão multiplicados por um fator de aceleração de 2

Figura 18: Módulo de elasticidade em tração (Módulo de Young) de PS de acordo com o envelhecimento. Tempos do envelhecimento artificial estão multiplicados por um fator de aceleração de 4 .

Figura 19: Módulo de elasticidade em tração (Módulo de Young) de PSAI de acordo com o envelhecimento. Tempos do envelhecimento artificial estão multiplicados por um fator de aceleração de 2

Figura 20: Temperaturas de transição vítrea de PS de acordo com o envelhecimento. Tempos do envelhecimento artificial estão multiplicados por um fator de aceleração de 4 .

Figura 21: Temperaturas de transição vítrea de PSAI de acordo com o envelhecimento. Tempos do envelhecimento artificial estão multiplicados por um fator de aceleração de 2 .

Figura 22: Resistências ao impacto IZOD de PSAI de acordo com o envelhecimento, convertidos para o sistema internacional. Tempos do envelhecimento artificial multiplicados por um fator de aceleração de 2 .

Figura 23: Índices de fluidez de PS de acordo com o envelhecimento. Tempos do envelhecimento artificial estão multiplicados por um fator de aceleração de 4 ......

Figura 24: Índices de fluidez de PSAI de acordo com o envelhecimento. Tempos do envelhecimento artificial estão multiplicados por um fator de aceleração de $2 \ldots .$. 
Figura 25: Índices de fluidez dos corpos de prova do ensaio de impacto de PSAI de acordo com o envelhecimento. Tempos do envelhecimento artificial estão multiplicados por um fator de aceleração de 2 .......................................... 70

Figura 26: Esquema visual qualitativo do perfil de amarelecimento de PS ............71

Figura 27: Esquema visual qualitativo do perfil de amarelecimento de PSAI ........71

Figura 28: Ensaio de tração de PS original........................................................79

Figura 29: Ensaio de tração de PS após 180 dias de envelhecimento natural .........79

Figura 30: Ensaio de tração de PS após 2160 horas de envelhecimento artificial... 80

Figura 31: Ensaio de tração de PSAI original.................................................... 80

Figura 32: Ensaio de tração de PSAI envelhecido 30 dias ................................... 81

Figura 33: Ensaio de tração de PSAI envelhecido 360 horas .................................81

Figura 34: Ensaio de tração de PSAI envelhecido 180 dias .................................. 82

Figura 35: Ensaio de tração de PSAI envelhecido 2160 horas ............................. 82

Figura 36: Corpos de prova de tração de PS originais e envelhecidos após a ruptura.

Figura 37: Corpos de prova de tração de PSAI originais e envelhecidos após a

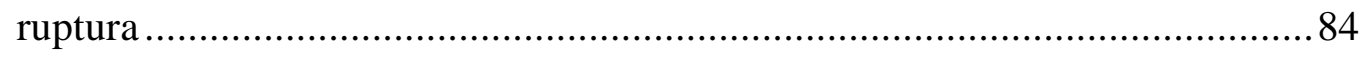




\section{LISTA DE TABELAS}

Tabela I: Resultados do ensaio de tração para o PS em envelhecimento natural......54

Tabela II: Resultados do ensaio de tração para o PS em envelhecimento artificial....

Tabela III: Resultados do ensaio de tração para o PSAI em envelhecimento natural..

Tabela IV: Resultados do ensaio de tração para o PSAI em envelhecimento artificial

56

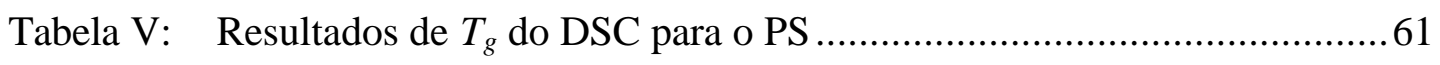

Tabela VI: Resultados de $T_{g}$ do DSC para o PSAI ...............................................62

Tabela VII: Resultados de impacto IZOD do PSAI, convertidos para o sistema

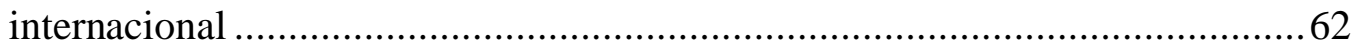

Tabela VIII: Resultados de índice de fluidez do PS ..........................................63

Tabela IX: Resultados de índice de fluidez do PSAI..........................................63

Tabela X: Resultados de índice de fluidez para corpos de prova de impacto do

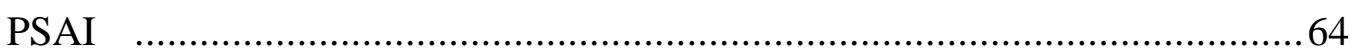




\section{LISTA DE ABREVIATURAS E SIGLAS}

ASTM American Society for Testing and Materials, sociedade americana que rege e publica as normas de testes para equipamentos e materiais

ABS Copolímero de acrilonitrila-butadieno-estireno

ASA Copolímero de SAN enxertado de um éster acrílico elastomérico

CPE Chlorinated polyethylene, polietileno clorado

DSC Differential Scanning Calorimetry, calorimetria exploratória diferencial

EVA Ethylene-vinyl acetate, polímero de etileno-vinil acetato

FTIR Fourier Transformed Infrared, infravermelho com transformada de Fourier - tipo de espectrofotômetro por absorção de raios infravermelho

GPC Cromatografia de permeação de gel

GFPP Glass fiber-reinforced polypropylene, polipropileno reforçado por fibra de vidro

HALS Hindered amine light stabilizer, estabilizante de luz composto de amina

HDT Heat-Distortion Temperature

HIPS High impact polystyrene, poliestireno de alto impacto

IPEN Instituto de Pesquisas Energéticas e Nucleares

IPT Instituto de Pesquisas Tecnológicas do Estado de São Paulo

MABS Methyl methacrylate-acrylonitrile-butadiene-styrene, polímero de metil metacrilato-acrilonitrila-butadieno-estireno

MBS Methyl methacrylate-butadiene-styrene, polímero de metil metacrilatobutadieno-estireno

MFR Melt Flow Rate, índice de fluidez

MIR Medium infrared, infravermelho médio, região do espectro eletromagnético

NIR Near infrared, infravermelho próximo, região do espectro eletromagnético, utilizada em alguns espectrofotômetros

PBI poli[2,2'-(m-fenileno)-5,5'-bibenzimidazola]

PE Polietileno

PP Polipropileno

PS Poliestireno 
PSAI Polestireno de alto impacto

PTFE Polytetrafluoroethylene, politetrafluoretileno

PVC Poli (cloreto de vinila)

SAN Copolímero de estireno-acrilonitrila

SEM Scanning electron microscopy, microscópio eletrônico de varredura

SBS Styrene-butadiene-styrene, copolímero de estireno-butadieno-estireno

UV radiação luminosa ultravioleta

UV-A radiação luminosa ultravioleta longa

UV-B radiação luminosa ultravioleta curta

WOM Weather-O-Meter, câmara de intemperismo artificial

XWOM Xenon-Arc Weather-O-Meter, câmara de intemperismo artificial com lâmpada de arco-xenônio 


\section{LISTA DE SÍMBOLOS}

$T_{g} \quad$ Glass transition temperature, temperatura de transição vítrea.

Temperatura na qual o polímero tem uma transição de comportamento do plástico para o vítreo quando resfriando.

$T_{m} \quad$ Melting temperature, temperatura de fusão cristalina. Temperatura na qual os cristalitos se desordenam, passando para o estado amorfo, quando em aquecimento. Não existe em polímeros $100 \%$ amorfos.

$\bar{M} \quad$ Média molar

$\bar{M}_{n} \quad$ Média Molar Numérica

$\bar{M}_{w} \quad$ Média Molar Mássica

$\lambda \quad$ comprimento de onda, usualmente medido em nanômetros para radiação UV

$\sigma_{e s c} \quad$ Tensão no limite de escoamento do ensaio de tração

$\sigma_{\text {rup }} \quad$ Tensão na ruptura do ensaio de tração

$\varepsilon_{\text {rup }} \quad$ Elongação na ruptura do ensaio de tração

E Módulo de elasticidade em tração, conhecido como Módulo de Young

$I_{s} \quad$ Impact strength, resistência ao impacto 


\section{RESUMO}

O estudo do comportamento de materiais em relação a intempérie, esforços, tempo, temperatura é fundamental para a escolha de materiais para uma dada aplicação.

O poliestireno é uma resina polimérica muito aplicada no mercado, pois é transparente e relativamente econômica, mas não é indicada para aplicações com muita exposição a radiações luminosas, já que é muito susceptível a intemperismos, não sendo recomendada para aplicações com excessiva exposição.

A adição de borracha (copolímero de estireno e butadieno) melhora algumas de suas propriedades, como resistência ao impacto e ductilidade, mas piora outras características, como a resistência à tração. Em relação ao intemperismo, apesar da borracha degradar-se rapidamente, ela protege o poliestireno da radiação ultravioleta.

Este estudo visa comparar as conseqüências da degradação por envelhecimento natural com o envelhecimento artificial acelerado do poliestireno e do poliestireno de alto impacto e a determinação da possível correlação entre eles.

Foram utilizados equipamentos de envelhecimento artificial, de ensaio de tração, impacto IZOD, índice de fluidez, uma estação de envelhecimento natural e equipamento de análise térmica (DSC).

Os resultados obtidos permitiram correlacionar os envelhecimentos natural e artificial em relação às propriedades medidas, sendo que para o poliestireno comum, o envelhecimento artificial acelerou a degradação em cerca de 4 vezes, enquanto que para o poliestireno de alto impacto, o fator de aceleração foi de cerca de 2 vezes. 


\begin{abstract}
The study of weathering materials regarding to climate, stresses, time, temperature, is essential to choose the materials for a purpose.

Polystyrene is a polymeric resin with much usage in the market as it is transparent and relatively cheap, but it is not indicated for outdoor purposes with much actinic radiation exposure, as it is very sensitive to weathering, tough not recommended to purposes with much exposure.

The addition of rubber (styrene-butadiene copolymer) improves some of its properties, like impact resistance and ductility, but decreases other properties, like tensile strength. Regarding the weathering, although the rubber degrades very quickly, it protects the polystyrene from the ultraviolet radiation.

This study aims to compare the consequences of the degradation by natural weathering and accelerated artificial weathering and try to correlate their results.

Equipments for artificial weathering, tensile strength, IZOD impact, melt flow, a natural weathering station and DSC thermal analysis equipment were used.

The results allowed the correlation between the natural and artificial weathering regarding the measured properties, as for the common polystyrene the artificial weathering accelerated the degradation in approximately 4 times, while for the high impact polystyrene the acceleration factor resulted in approximately 2 times.
\end{abstract}




\section{Introdução e objetivos}

\subsection{Introdução}

O estudo comparativo entre os envelhecimentos natural e artificial de um dado material é extremamente importante e se justificam plenamente investimentos em equipamentos que acelerem os resultados de análises de degradação por intemperismo que tenham resultados válidos. Como os equipamentos reproduzem apenas parte da radiação solar e cada material absorve algumas faixas da radiação natural do sol, alguns materiais podem ter bons resultados com um dado equipamento ou não. Além da análise da degradação feita numa câmara de intemperismo artificial ser muito mais rápida que a exposição natural, ela tem a grande vantagem de ser reprodutível.

A adição de borracha ao poliestireno influencia suas características físicas e químicas, gerando alterações nas propriedades mecânicas e no mecanismo de fotodegradação.

O poliestireno para uso geral, também chamado de GPPS (General Purpose PolyStyrene), cristal ou simplesmente PS, é um polímero amorfo, transparente, frágil, fácil de processar e barato. É utilizado na fabricação de canetas, caixas de fita cassete e CD's, bandejas de geladeiras e congeladores.

O poliestireno de alto impacto (PSAI), ou HIPS (High-Impact PolyStyrene), é um polímero também amorfo, mas com adição de borracha (polibutadieno) por “grafting" (enxerto), isto é, moléculas de polibutadieno são adicionadas à cadeia principal do poliestireno através de reações químicas e não simplesmente por mistura, como em blendas. O poliestireno de alto impacto pode, então, ser formulado a partir do poliestireno puro em blenda com o poli (estireno-g-butadieno), este descrito, com alto teor de polibutadieno, resultando numa flexibilidade de formulações, atingindo um mercado maior para os fabricantes de compostos da resina. O poliestireno de alto impacto é amorfo, branco, dúctil, fácil de processar e também muito suscetível à radiação solar. É utilizado na fabricação de caixas de 
televisores, aparelhos de som, toca-fitas/CD de automóveis, copos descartáveis, revestimento interno de geladeiras e congeladores.

\subsection{Objetivos}

Os objetivos deste trabalho são validar o uso de equipamento de intemperismo artificial para prever o comportamento do poliestireno no envelhecimento natural e avaliar a influência da borracha em sua formulação para atuação em aplicações que requerem alto impacto com relação ao envelhecimento.

A correlação entre os resultados de envelhecimento artificial com os resultados de envelhecimento natural utilizando-se um fator geral de aceleração é um modo de validar os resultados de uma câmara de intemperismo artificial.

A adição de borracha no poliestireno permite verificar sua influência nos mecanismos de degradação do copolímero.

Este presente trabalho tem também como objetivo avaliar os experimentos que mais podem contribuir com a correlação de dados. 


\section{Revisão Bibliográfica}

\subsection{Polímeros}

A palavra "polímero" vem do grego, significando "muitas partes". São cadeias compridas com unidades repetitivas de estrutura idêntica em vários tamanhos de cadeias. Na natureza encontramos proteínas, celulose e seda, materiais poliméricos, assim como a borracha natural, esta última já sintetizada artificialmente, o poliisopreno (Fried, 1995).

\subsubsection{Histórico}

A história dos polímeros começa nos anos 1830, com a vulcanização do látex de borracha natural em um elastômero para uso em pneus, por Charles Goodyear. Logo após, em 1847, Christian F. Schönbein reagiu celulose com ácido nítrico, produzindo nitrato de celulose, que foi usado nos anos 1860's como o primeiro termoplástico, o "celluloid" (celulóide).

Leo Baekeland produziu o "Bakelite" (resina fenol-formaldeído) em 1907 e, em 1912, a General Electric desenvolveu o "glyptal" (gliptal, resina de poliéster insaturado) como resina protetiva de recobrimento.

Nos anos 1930, pesquisadores da Du Pont nos Estados Unidos produziram vários novos polímeros, incluindo borracha sintética e materiais mais exóticos, como o Nylon $^{\mathrm{TM}}$ (náilon) e o Teflon ${ }^{\mathrm{TM}}$. Em 1938, a Dow produziu várias toneladas de poliestireno e, em 1939, o polietileno (de baixa densidade) foi fabricado pela primeira vez por cientistas da ICI na Inglaterra.

Esforços para o desenvolvimento de novos materiais poliméricos, particularmente a borracha sintética, foram intensificados durante a Segunda Guerra Mundial, quando muitos materiais naturais tiveram pouca oferta de fornecimento para tanta demanda. Nos anos 1950, Ziegler e Natta desenvolveram, independentemente, uma família de catalisadores de metais de transição estereoespecíficos que levaram à 
comercialização do polipropileno como a maior "commodity" plástica, isto é, um material de uso comum vendido em grande quantidade.

Nos anos 1960 e 1970, um número de polímeros de alto desempenho foi desenvolvido, competindo favoravelmente com materiais mais tradicionais, como metais, para aplicações automotivas e aeroespaciais.

Nos anos 1990, materiais poliméricos foram usados em quase todas as áreas da vida diária e sua produção e fabricação, grandes indústrias mundiais (Fried, 1995).

\subsubsection{Propriedades dos Plásticos - Aditivos}

As palavras plásticos e polímeros são usualmente tomadas como sinônimos, mas existe a distinção entre o material puro (polímero) e o formulado para uso. O polímero é o material resultante do processo de polimerização e são raramente utilizados em sua forma pura. Quando aditivos são utilizados é que o termo plástico se aplica (Crawford, 1989).

A seguir, exemplos de aditivos e razões de uso:

\subsubsection{Antiestáticos}

A maioria dos polímeros são maus condutores de corrente elétrica, sendo suscetíveis a formação de eletricidade estática, resultando em riscos de formação de faíscas e atração de partículas de sujeira. Os agentes antiestáticos atraem umidade para a superfície do plástico, aumentando a condutibilidade elétrica (Crawford, 1989).

Lunardi (1987) disse: “A maior parte dos polímeros são intrinsicamente isolantes, enquanto a condutividade elétrica, por sua vez, ocorre devido à presença de umidade ou grupos polares na cadeia ou ainda pela incorporação de negro-de-fumo condutivo e/ou partículas metálicas." Os materiais amorfos possuem no intervalo de energias proibidas, entre as bandas de valência e de condução, estados de energias permissíveis onde a mobilidade dos transportadores é menor, funcionando como defeitos, atrasando ou espalhando o trânsito do transportador de carga. Estes estados localizados estão associados a grupos substituintes, ramificações, dobras de cadeia, 
dipolos, ligações cruzadas, finais de cadeia, interfaces e até variações morfológicas. O salto entre estes estados localizados conduz eletricidade, o que não acontece no poliestireno, que é 100\% amorfo, sendo portanto, um excelente isolante. O cobre, que é um excelente condutor, tem sua condutividade reduzida após sofrer encruamento, devido ao aumento do número de deslocamentos e defeitos.

Já foram descritas atrações de partículas por interação eletrostática pela adsorção de partículas aniônicas de poliestireno numa superfície catiônica de filmes poliméricos. Pode haver, dependendo da carga, atração ou repulsão eletrostática (Serizawa; Kamimura; Akashi, 2000).

Cassidy et al. (1999) demonstra o fenômeno da eletrostática pela adesão de partícula ou extensão da adsorção, pela medição da carga eletrostática em um ciclone carregador de partículas.

\subsubsection{Cargas}

Fibras, escamas ou pós de materiais inorgânicos, como fibra de vidro, carbonato de cálcio, sílica e argilas são utilizados para dois fins: melhorar as propriedades mecânicas do plástico ou como cargas propriamente ditas, ou seja, para economizar a resina (polímero) e baratear o produto (Crawford, 1989).

\subsubsection{Agentes de Acoplamento}

Usualmente silanos ou titanatos são utilizados para reforçar a ligação entre o plástico e a carga mineral (Crawford, 1989).

\subsubsection{Retardantes de Chama}

Como os polímeros são materiais orgânicos, muitos deles são inflamáveis. Aditivos que contém cloreto, brometo, fósforo ou sais metálicos reduzem a ocorrência ou espalhamento de chama (Crawford, 1989). 
Quando sujeitos a um fluxo de calor suficiente por um tempo suficiente, todos os polímeros orgânicos degradarão termicamente. Na ausência de oxigênio, a degradação térmica é chamada de pirólise. Na presença de oxigênio, a degradação térmica é chamada de pirólise oxidativa ou de degradação termo-oxidativa. Os agentes retardantes de chama são adicionados para alterar o processo de combustão seguindo estratégias como inibição da fase vapor dos gases de combustão; alteração do caminho de degradação térmica provendo um processo de baixa energia que promova reações em estado sólido, levando à carbonização; ou formação de uma camada protetora para isolar contra a energia térmica (Fried, 1995).

\subsubsection{Agentes de processamento / Lubrificantes}

Graxa ou estearato de cálcio reduzem a viscosidade dos plásticos derretidos, facilitando os processos de moldagem. Óleos minerais podem ser utilizados em formulações de polímeros para facilitar a desmoldagem (Crawford, 1989).

Os lubrificantes são adicionados aos polímeros para melhorar a fluidez durante o processamento, seja reduzindo a viscosidade de fusão cristalina (lubrificantes internos), ou reduzindo a adesão entre as superfícies metálicas do equipamento de processamento com o polímero fundido (lubrificantes externos). As principais categorias de lubrificantes incluem amidas, ésteres, estearatos metálicos, graxas e ácidos. O maior mercado para lubrificantes de processamento é para o PVC, para o qual os estearatos são freqüentemente utilizados. Outros lubrificantes incluem óleos minerais e poliolefinas de baixa massa molar. Fluidos de silicone organofuncionais podem ser usados como agentes desmoldantes internos para poliuretanos reagidos na moldagem por injeção (Fried, 1995).

\subsubsection{Colorantes}

Usados para colorir os plásticos. Podem ser corantes solúveis e pigmentos inorgânicos ou orgânicos dispersos no plástico durante o processamento. Para o caso 
de polímeros termofixos, a solução do corante ou a dispersão do pigmento devem estar completas antes das reticulações serem todas formadas (Fried, 1995).

\subsubsection{Plastificantes}

Materiais de baixa massa molar que alteram as propriedades e características de moldagem do plástico. Um exemplo importante é a produção de graus flexíveis do poli (cloreto de vinila) pelo uso de plastificantes (Crawford, 1989).

\subsubsection{Reforçadores}

A resistência e a rigidez dos polímeros são melhoradas pela adição de fibras de vidro, de carbono, etc. (Crawford, 1989).

\subsubsection{Estabilizantes}

Previnem a deterioração do polímero devido a fatores ambientais. Anti-oxidantes são adicionados ao ABS, polietileno e poliestireno. Estabilizantes térmicos são necessários quando se processa o poli (cloreto de vinila). Estabilizantes também previnem deterioração por radiação ultravioleta (Crawford, 1989).

\subsubsection{Biocidas}

Normalmente as poliolefinas e polímeros vinílicos são particularmente resistentes a ataques de bactérias, enquanto a borracha natural, celulose e seus derivados e alguns poliésteres são susceptíveis a ataques microbianos. Um biocida é um agente químico que controla ou impede o crescimento bacteriano. Dependendo da ação, são usadas as terminologias bactericidas, bacteriostáticos, anti-mofo, fungicidas, fungiostáticos, 
germicidas e algicidas. $\mathrm{O}$ biocida ideal é aquele que é tóxico para o microrganismo alvo, mas seguro para humanos e animais (Fried, 1995).

\subsubsection{Agentes de cura}

O termo cura refere-se tipicamennte ao processo de aplicação de calor (e pressão) para modificar as propriedades de borrachas ou de resinas termofixas. No processo de cura, vários aditivos (agentes de cura) incluindo um número de compostos com enxofre, são utilizados para promover as reticulações na borracha, isto é, a vulcanização, ou a formação da rede termofixa. (Fried, 1995).

\subsubsection{Modificadores de impacto e de distorção térmica}

Blendas de um polímero com outro com $T_{g}$ maior ou menor podem modificar a $T_{g}$ ou HDT do outro polímero. Modificadores de impacto normalmente incluem poliestireno de alto impacto (HIPS), polietileno clorado (CPE) e uma variedade de copolímeros ou terpolímeros como SAN, ABS, EVA, MBS e MABS (Fried, 1995).

\subsubsection{Compatibilizadores}

Muitos polímeros são imiscíveis, havendo separação de fases no processo. As propriedades mecânicas destas blendas imiscíveis são normalmente muito ruins por uma força interfacial inadequada entre a fase dispersa e a matriz. Uma variedade de aditivos pode ser usada para promover miscibilidade por redução da tensão interfacial. Os compatibilizantes quimicamente reativos reagem com os componentes da blenda e são, portanto, efetivos para muitas composições de blendas, isto é, para várias porcentagens de fase dispersa em relação à matriz. Compatibilizantes não reativos são tipicamente copolímeros em bloco ou em enxerto dos homopolímeros da blenda e são mais específicos em sua ação (Fried, 1995). 


\subsubsection{Classificações}

\subsubsection{Termoplásticos, termofixos e elastômeros}

\subsection{Termoplásticos}

Os polímeros termoplásticos possuem cadeias moleculares longas ligadas por forças atrativas de Van der Waals, relativamente fracas. Quando o material é aquecido, estas forças se enfraquecem e ele se torna macio e flexível e eventualmente, em temperaturas elevadas, derretidos como um líquido viscoso. Quando o material é resfriado, volta a solidificar. Este ciclo térmico pode ser repetido quase que indefinidamente e a maior vantagem disso é a capacidade de processamento. A desvantagem é que suas propriedades são sensíveis ao calor. Exemplos de termoplásticos: polietileno, PVC, poliestireno, poliamida (náilon), acetato de celulose, poliacetal, policarbonato, poli (metil metacrilato) e polipropileno.

\subsection{Termofixos}

Polímeros termofixos são formados através de reações em duas etapas. Primeiramente as cadeias longas são formadas, como nos termoplásticos, mas ainda com capacidade reativa. Durante a moldagem ocorre o segundo estágio da reação (ligações cruzadas entre as cadeias - "crosslinking"), usualmente sob calor e pressão. Quando resfriado, uma estrutura fixa reticulada é formada, sendo incapaz de amolecer novamente por aplicação de calor. Exemplos: fenol-formaldeído, melamina-formaldeído, uréia-formaldeído, resinas epoxy e alguns poliésteres.

\subsection{Elastômeros}

Borrachas convencionais são membros da família dos polímeros, com longas cadeias em forma de molas e torcidas de maneira aleatória, com flexibilidade suficiente para sofrer grandes deformações. Em seu estado "verde", elas se deformam 
permanentemente. As cadeias são então ancoradas por cura (vulcanização - por reação entre as duplas ligações de uma cadeia polimérica com outra, também chamada de reticulação), de uma maneira similar às ligações dos termofixos, prevenindo o escorregamento das cadeias, mas permitindo a movimentação das "molas" e a flexibilidade. As borrachas termoplásticas são compostos de partículas de borracha em uma matriz termoplástica, tendo a característica de flexibilidade com a possibilidade de moldagem (Crawford, 1989).

\subsection{Blendas}

A formação de blendas poliméricas segue o mesmo princípio das ligas metálicas: consegue-se propriedades em um material adicionando-se vários outros. Um exemplo de sucesso é o ABS (acrilonitrila, butadieno e estireno). Na formulação, levam-se em conta as características de cada componente e a compatibilidade entre eles (Crawford, 1989).

A compatibilidade em blendas poliméricas pode ser estudada por DSC (Differential Scanning Calorimetry), calorimetria exploratória diferencial, medindo a $T_{g}$ (temperatura de transição vítrea) e temperatura de fusão $\left(T_{m}\right)$, quando houver, do material polimérico. Blendas miscíveis mostram transições / picos bem definidos, enquanto blendas imiscíveis mostram transições separadas. No caso de misturas intermediárias, em casos limites de miscibilidade, transições largas são observadas (Asaletha; Kumaran; Thomas, 1998).

\subsubsection{Mecanismo de polimerização, segundo Wallace Carothers:}

\subsection{Adição}

Quando um monômero torna-se reativo e vai incorporando outro monômero, cedendo-lhe a reatividade. O poliestireno é um exemplo importante de poliadição, assim como os polímeros derivados do etileno. 


\subsection{Condensação}

Reações aleatórias entre 2 moléculas, podendo ser monômero, oligômero ou intermediário de massa molar maior, tendo terminais funcionais, como ácido carboxílico ou grupos hidroxílicos. O nome condensação se dá pela liberação de moléculas pequenas na forma de gás, água ou sal. Ex.: poliamida 6,6 pela condensação de ácido adípico com hexametileno diamina, eliminando 2 moléculas de água para cada unidade repetitiva (Fried, 1995).

\subsubsection{Estrutura polimérica}

Quando a cadeia principal do polímero tem sua "espinha dorsal" composta apenas de carbonos, dependendo dos tipos de monômeros (alcanos, alcenos, alcinos) as ligações serão simples, duplas ou triplas, mas eles serão sempre polímeros de estrutura de base carbônica, com ou sem variações.

Estas variações podem ser estrutura com carbono e oxigênio, em poliéteres, poliésteres de ácidos carboxílicos, polianidridos de ácidos carboxílicos e policarbonatos; carbono e enxofre, como politioéteres e polisulfonas; carbono e nitrogênio, como as poliaminas, poliiminas, poliamidas e poliuréias.

\subsubsection{Homopolímeros e copolímeros}

Os homopolímeros têm apenas um tipo de unidade repetitiva; os copolímeros têm duas; os terpolímeros têm três. As unidades repetitivas, quando mais de uma, podem se arranjar de maneira aleatória, alternada, em blocos, ou por enxerto ("graft").

\subsubsection{Taticidade (isômeros)}

Quando existe a possibilidade de uma distribuição espacial assimétrica para o mesmo polímero, chamam-se isômeros. O isômero é chamado de isotático quando um grupo 
substituinte está todo de um lado da estrutura polimérica; sindiotático, quando um grupo substituinte se alterna entre um lado e outro com outro grupo substituinte ou hidrogênio; ou atático: quando não existe taticidade, ou seja, um padrão durante a extensão da cadeia polimérica.

\subsubsection{Massa molar}

\subsection{Distribuição molecular}

A reação química de polimerização produz cadeias de diversos tamanhos, dependendo do caso, com uma distribuição de tamanhos mais larga ou mais estreita, de acordo com o controle que se tem sobre ela.

2.1.3.6.2. Médias $\bar{M}, \bar{M}_{n}, \bar{M}_{w}$.

Para se caracterizar um polímero, usam-se as médias molares:

$$
\begin{aligned}
\bar{M} & =\frac{\sum_{i} N_{i} M_{i}^{\alpha}}{\sum_{i} N_{i} M_{i}^{\alpha-1}}, \text { ou } \\
\bar{M} & =\frac{\int_{0}^{M} N M^{\alpha} d M}{\int_{0}^{M} N M^{\alpha-1} d M}, \text { para medições contínuas; }
\end{aligned}
$$

Chamam-se: Média Molar Numérica $\bar{M}_{n}$, quando $\alpha=1$; Média Molar Mássica $\bar{M}_{w}$, quando $\alpha=2$ e média $z$ quando $\alpha=3$. Estas diferentes médias são utilizadas para demonstrar além de apenas o tamanho médio das cadeias poliméricas, também a distribuição de diversos tamanhos moleculares (Fried, 1995). A polidispersão é a razão entre a média molar $\bar{M}_{w}$ e a Média Molar Numérica $\bar{M}_{n}$ (George, 1995). 


\subsubsection{Morfologia e transições térmicas}

A classificação de polímeros quanto a ordenação das cadeias é quando ele é cristalino, ou seja, suas cadeias são ordenadas, ou amorfo, quando suas cadeias apresentam orientações aleatórias.

\subsection{Polímeros Amorfos}

Onde as cadeias poliméricas estão dispostas de forma aleatória, enrolada e desordenada, chama-se fase amorfa. Por exemplo, o poliestireno atático é um polímero $100 \%$ amorfo.

\subsection{Temperatura de transição vítrea}

Abaixo de certa temperatura, chamada de transição vítrea $\left(T_{g}\right)$, movimentações cooperativas de grande amplitude das cadeias individuais não podem ocorrer, apenas pequenas movimentações envolvendo muitos grupos contíguos ao longo da cadeia principal ou de grupo substituinte, chamadas de processos de relaxação secundários, que podem ocorrer em temperaturas tão baixas quanto $70 \mathrm{~K}$. As temperaturas de transição vítrea variam de $150 \mathrm{~K}$ para o polidimetilsiloxano, que é muito flexível, até acima de $600 \mathrm{~K}$, como os 700 a $773 \mathrm{~K}$ para o altamente rígido aromático PBI, poli [2,2'-(m-fenileno)-5, '5'-bibenzimidazola].

\subsection{Polímeros cristalinos}

Os polímeros com estruturas altamente regulares, como o polietileno e o polipropileno isotático, podem se organizar em estruturas chamadas de cristalitos. Cada cristalito consiste de linhas de cadeias dobradas. Como a energia necessária para dobrar as cadeias é grande e a cristalização ocorre sempre acima da $T_{g}$. 
$\mathrm{Na}$ prática, não é possível para um plástico moldado ter uma estrutura completamente orientada, devido à natureza física complexa das cadeias moleculares. Polietileno e poliamida podem atingir altos graus de cristalinidade, $96 \%$ e $60 \%$, respectivamente, mas podem ser melhor descritos como parcialmente ou semi-cristalinos (Mano, 1991). A densidade dos polímeros aumenta quando se cristalizam, pela proximidade do "empacotamento" das moléculas.

As características típicas de polímeros que possuem cristalinidade são rigidez, principalmente em temperaturas elevadas; baixa fricção; dureza; resistência a quebras por esforços ambientais; podem ser efetivamente reforçados; habilidade de serem esticados; maior resistência à fluência que quando amorfos, ou em relação a polímeros amorfos.

Os plásticos cristalinos são sempre opacos e apresentam relativamente alto "rechupe" (ou encolhimento) durante a moldagem.

\subsection{Temperatura de fusão cristalina}

Se a temperatura for tão alta que as cadeias dobradas fiquem instáveis, a energia térmica desordena os cristalitos, ocorrendo uma transição cristalino-amorfa na temperatura de fusão cristalina $T_{m}$. Temperaturas de fusão cristalina podem variar de 334K para poliésteres simples, como a policaprolactana, até acima de $675 \mathrm{~K}$ para poliamidas aromáticas, como o Nomex ${ }^{\mathrm{TM}}$, poli (m-fenileno isoftalamida).

Quando o polímero é cristalizado a partir do estado fundido ou de solução concentrada, os cristalitos podem organizar-se em grandes estruturas chamadas esferulitos, cada um contendo linhas de cristalitos lamelares, tipicamente orientados com o eixo da cadeia perpendicular à direção radial de crescimento do esferulito.

Uma aproximação comum é que $T_{g}$ costuma ser cerca de metade a dois terços de $T_{m}$, quando expressos em Kelvin (temperatura absoluta). Podem ser determinados por muitas técnicas, incluindo medidas de volume (dilatometria), calor específico (calorimetria) e propriedades mecânicas, particularmente Módulo de Young de um teste de tração versus temperatura de análise (análise mecânica dinâmica). 
O DSC, calorimetria exploratória diferencial, usa aquecedores independentes para dois suportes de platina, um contendo o polímero mecanicamente selado numa pequena panela de alumínio e o outro contendo uma panela vazia como referência. A diferença de potência necessária para manter as duas amostras na mesma temperatura durante um ciclo de aquecimento é gravada como função da temperatura.

Efeito da Massa Molar na $T_{g}$ : a temperatura de transição vítrea aumenta com a massa molar para massas molares pequenas, mas chega em um ponto para massas molares moderadas em que aumentos na massa molar influem muito pouco na $T_{g}$. O raciocínio desta dependência é similar para $T_{m}$ (Fried, 1995). 


\subsection{Poliestireno}

Conhecidas desde 1845, as resinas de poliestireno tiveram grande importância industrial no início da segunda guerra mundial (1939), graças aos estudos realizados por Ostro Mislensky e Staudinger, na Alemanha. Nos anos 1990 foi um dos termoplásticos mais consumidos, devido ao baixo custo, menor peso e boas propriedades elétricas (como baixa condutibilidade elétrica), transparência, alto brilho e boa resistência a alguns ácidos fortes (Corazza, 1995).

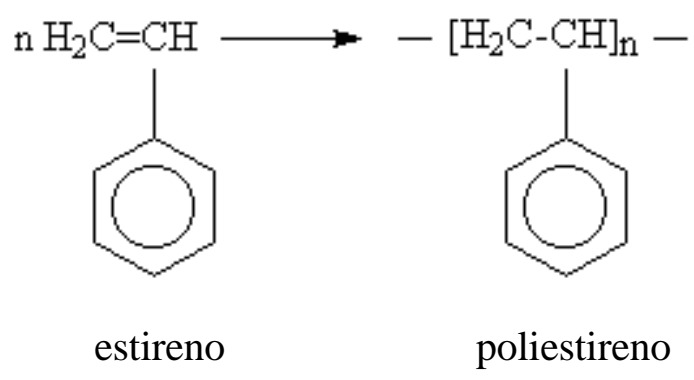

O poliestireno é um polímero comum. A unidade repetitiva tem a mesma composição $\left(\mathrm{C}_{8} \mathrm{H}_{8}\right)$ como o monômero de baixa massa molar, o estireno, de onde o poliestireno é sintetizado. $\mathrm{O}$ número de unidades repetitivas é indicado pelo índice $\mathrm{n}$. No caso de graus comerciais do poliestireno, o valor médio de n pode ser 1000 ou mais. Dado que a massa molar da unidade repetitiva do poliestireno é 104, o valor de 1000 para $n$ representa uma média de massa molar de 104000. Moléculas com menos de 10 unidades repetitivas são denominadas oligômeros e demonstram propriedades térmicas e mecânicas muito diferentes quando comparadas com os polímeros de alta massa molar. $\mathrm{O}$ estireno oligomérico com 7 unidades repetitivas $(\mathrm{n}=7)$ é um líquido viscoso à temperatura ambiente, enquanto o poliestireno grau comercial, de alta massa molar, é um sólido frágil que não amolece até que seja aquecido acima de $100^{\circ} \mathrm{C}$ (Fried, 1995). 


\subsubsection{Produção do Estireno}

O monômero para a produção do poliestireno é o estireno, um hidrocarboneto líquido com ponto de ebulição de $145^{\circ} \mathrm{C}$ e ponto de solidificação de $-30,6^{\circ} \mathrm{C}$. Quando puro, é incolor com um odor agradável e adocicado, ao contrário do que se observa, pois o odor irritante aparece devido à contaminação por aldeídos formados quando da exposição ao ar livre.

Sua produção pode vir da desidrogenação do etil benzeno, que é obtido a partir da alquilação do etileno e do benzeno (provenientes do petróleo e da hulha, respectivamente), na presença de um catalisador, como por exemplo o cloreto de alumínio.

A desidrogenação do etil benzeno ocorre pela ação do calor $\left(600\right.$ a $\left.800^{\circ} \mathrm{C}\right)$ na presença de óxidos metálicos, como óxidos de zinco, cálcio, magnésio, ferro ou cobre. A reação é endotérmica com aumento de volume, usando-se pressão reduzida (Corazza, 1995).

\subsubsection{Polimerização do estireno}

\subsubsection{Em suspensão}

O monômero é suspenso em água com um catalisador solúvel em estireno e não em água (como o peróxido de benzoíla), formando gotículas por agitação mecânica estabilizada por materiais solúveis em água facilmente removíveis por lavagem ou filtração, como o álcool polivinílico [poli (álcool vinílico)]. A polimerização por suspensão ou por batelada é mais flexível e atende às várias solicitações técnicas do mercado, por processar quantidades menores. Acaba sendo uma polimerização em massa (nas gotículas) sem a desvantagem da dificuldade de controle da temperatura que ocorre nesta operação (Corazza, 1995). 


\subsubsection{Por massa contínua}

É, como na reação por suspensão, uma reação exotérmica que ocorre na presença de catalisadores, iniciada em um reator, passa pelas fases de propagação e terminações nos outros reatores, chegando a um rendimento de conversão acima de $80 \%$ (Corazza, 1995).

\subsubsection{Tipos de poliestireno}

\subsubsection{Poliestireno comum}

Homopolímero de estireno que recebe pequenas quantidades de lubrificantes, tanto de ação externa quanto interna, para facilitar o fluxo e as moldagens (Corazza, 1995).

\subsubsection{Poliestireno resistente ao calor}

Basicamente igual ao comum, mas devido a alta massa molar, não se distorce, mesmo imerso em água a $95^{\circ} \mathrm{C}$. A temperatura de distorção é $15^{\circ} \mathrm{C}$ maior que a do poliestireno comum e ele é mais difícil de ser processado (Corazza, 1995).

\subsubsection{Poliestireno resistente ao impacto}

Elastômeros são incorporados ao poliestireno em diversas proporções para eliminar a fragilidade do material e usá-lo em outras aplicações. Podem ser divididos em poliestirenos de médio e alto impactos, pela variação de 4 a $9 \%$ de concentração de elastômeros. Podem ser produzidos por dois sistemas de adição de borracha:

\subsection{Mistura mecânica}

Em moinho de 2 rolos, num misturador tipo banbury ou máquina de extrusão, de preferência com duas roscas. 


\subsection{Copolimerização "graft" (por enxerto)}

Diretamente no reator de polimerização, dissolvendo a borracha em estireno e polimerizando a mistura pelos processos de massa, solução, suspensão ou emulsão (Corazza, 1995).

\subsubsection{Aplicações do poliestireno}

Características como estabilidade dimensional, baixa densidade, baixa condutibilidade elétrica, alto índice de refração, baixo custo e possibilidade ilimitada de cores, o poliestireno é utilizado em artigos industriais, como peças de máquinas e veículos, caixas para rádio e televisão, grades de aparelhos de ar condicionado, peças internas e externas de aparelhos eletrodomésticos, circuladores de ar, ventiladores, refrigeradores, exaustores, motores elétricos, cassetes, estojos e carretéis para filme, carretéis de linha, peças para aparelhos eletrônicos, de telecomunicações, toca-fitas para carros, assentos, box de chuveiro e outras peças da linha sanitária, saltos e solas de calçados.

Outras aplicações importantes são embalagens, como caixas, tampas, potes, vasilhames, embalagens de proteção contra choque, etc.; artigos domésticos, como pratos, talheres, copos, artigos para cozinha e higiene, artigos para papelaria, bijouterias, etc.; utensílios diversos, como canetas, estojos, réguas, transferidores, brinquedos, jogos, etc. e artigos descartáveis, como copos para café, água, refrigerantes e iogurte, barbeador, seringas, escova dental, etc. (Corazza, 1995). 


\subsubsection{Propriedades do Poliestireno}

\subsubsection{Poliestireno Cristal}

Termoplástico duro, transparente, rígido, resistente à tração (cerca de $550 \mathrm{~kg} / \mathrm{cm}^{2}$ ) e alto índice de refração $(1,59)$.

Amolece a cerca de $90-95^{\circ} \mathrm{C}$ e a $180^{\circ} \mathrm{C}$ pode ser facilmente moldado por injeção (usualmente entre 160 e $280^{\circ} \mathrm{C}$ ).

Emite som com característica metálica quando cai sobre uma superfície dura.

É completamente inodoro, insípido e atóxico.

Queima com chama fuliginosa, amarelo-alaranjada, lentamente e não se extingue, com odor semelhante a jasmim.

Baixa massa específica, de 1,04 a 1,07 g/ $\mathrm{cm}^{3}$.

Baixo custo

Possui usualmente boa estabilidade dimensional e pequena absorção de umidade.

Excepcionais propriedades elétricas, com baixíssima condutibilidade elétrica, como Melo (1987) afirma, comparável, juntamente com o PTFE, à condutibilidade elétrica do quartzo, ou seja, é um dos materiais mais isolantes eletricamente, da ordem de $10^{-18} \mathrm{Siemens} / \mathrm{cm}$ que permanecem constantes numa grande faixa de temperatura e freqüência.

Fácil pigmentação.

Quimicamente é resistente a alguns ácidos fortes e aos álcalis e é insolúvel em hidrocarbonetos alifáticos e nos álcoois inferiores. É solúvel em ésteres, hidrocarbonetos aromáticos, álcoois superiores e hidrocarbonetos clorados.

Possui ótimas propriedades óticas, sendo que a transparência do poliestireno é da ordem de 87 a $92 \%$ da radiação incidente (Corazza, 1995).

\subsubsection{Poliestirenos modificados}

Nos poliestirenos modificados, a resistência ao impacto é superior à do poliestireno comum. A resistência à tração e o módulo de elasticidade são menores que no 
poliestireno comum, mas o alongamento pode melhorar de 10 a 50\%, dependendo da quantidade de elastômero incorporado, melhorando a tendência à quebra, embora se forçado além de um determinado ponto, a área que sofreu a tensão torna-se branca. Pode-se inserir metais na peça de poliestireno.

A presença de elastômeros afeta as propriedades elétricas, aumentando as perdas de potência de um fator de 10; a absorção de água aumenta de 2 a 3 vezes e a resistência ao calor diminui.

O poliestireno não possui boa resistência a intempéries. A ação desta é mais acentuada no poliestireno modificado (Corazza, 1995).

Adição apropriada de pequenas quantidades de borracha pode melhorar a tenacidade de termoplásticos normalmente frágeis, como o poliestireno. A interpenetração das fases é o fator mais importante para a eficiência do composto, tanto que polimerizar o poliestireno em presença de borracha resulta em maiores valores de resistência ao impacto em comparação a blendas. Em contrapartida, as resistências à tração dos poliestirenos de alto impacto são menores que as dos poliestirenos comuns (Pittolo; Burford, 1986). 


\subsection{Degradação de Polímeros}

\subsubsection{Introdução}

Uma definição ampla de envelhecimento se refere a qualquer processo degradativo produzido pela interação entre um material e um ambiente, alterando a estrutura do material e de suas propriedades dimensionais, mecânicas, elétricas, químicas ou térmicas (Berna, 1991).

Degradação é o resultado de interações complexas de efeitos sinérgicos de radiação, temperatura e umidade, assim como outros fatores do ambiente (Searle; 1989).

A degradação de materiais em serviço é de fundamental importância para a indústria, pois caso um determinado material se desgasta antes do tempo em que se espera ou que se garanta, o cliente vai exigir da empresa uma reposição ou simplesmente procurar outro fabricante.

Os polímeros sofrem degradação em vários ambientes e condições de serviço, tendo sua vida útil limitada, dependendo da agressão sofrida. Muitos polímeros são susceptíveis a degradação proveniente de intemperismo, em que reações fotoquímicas, envolvendo fótons de ultravioleta solar e oxigênio atmosférico, levando a quebras de cadeias moleculares. Estas reações podem ser aceleradas por temperaturas elevadas causadas pelo calor proveniente do sol, presença de tensões (aplicadas externamente ou tensões residuais do processo de conformação), gradiente de temperatura ou diferenças de coeficientes de expansão térmica em diferentes locais dentro do molde (White; Turnbull, 1994).

Polímeros sintéticos, como os plásticos, e polímeros naturais, como a madeira (material composto), são extensivamente usados na indústria da construção, aplicações externas e exposições à luz solar são rotina nesse tipo de mercado. A radiação UV-B afeta negativamente as propriedades mecânicas destes materiais, reduzindo suas vidas úteis (Andrady et al., 1998), pela degradação com cisão de cadeias causada por formação de radicais livres.

Com o uso, e até mesmo antes, ou seja, em seu processamento, os polímeros sofrem modificações em sua estrutura ao longo do tempo, como cisão da cadeia principal, que tem efeitos mais drásticos em polímeros semi-cristalinos, já que perdem a 
ductilidade; ocorrem reações de reticulação, quando duas macromoléculas reagem entre si, unindo-se; alteração na estrutura química, levando a formação de cor e mudanças nas propriedades elétricas e químicas e degradação ou eliminação dos aditivos presentes.

As causas podem ser ataques físicos ou químicos, como a radiação ultravioleta, quebrando a cadeia principal e fragilizando o polímero (Rabello, 2000).

A sinergia de efeitos entre a radiação UV com outros fatores, como a temperatura, é que vai determinar a extensão de tal redução na vida útil do material (Andrady et al., 1998).

Para proteger os plásticos, usam-se agentes foto-estabilizantes protetores de superfície (que podem conter polímeros) (Andrady et al., 1998).

Se o material resiste por mais tempo que o necessário, pode ser que se gastou estabilizante a mais.

Os fatores que devem ser levados em conta são estrutura química e molecular do polímero; composição (aditivos e impurezas presentes); histórico do processamento, como efeitos térmicos e mecânicos e estrutura física (orientação molecular, morfologia, grau de cristalinidade, etc.) e condições de uso (temperatura, umidade, presença de fontes de radiação, poluentes, etc.) (Rabello, 2000).

Qualquer aumento na exposição do meio ambiente à radiação UV-B, devido a danos na camada de ozônio tenderá a diminuir a vida útil destes materiais expostos (Andrady et al., 1998).

\subsubsection{Tipos de Envelhecimento}

Envelhecimento natural: expressão com duplo sentido: envelhecimento de um material submetido a influência dos elementos naturais, intempéries, etc., ou o envelhecimento de um material em suas condições de utilização. Talvez o melhor termo a ser utilizado seria especificando as condições ou características da exposição: exemplos: envelhecimento climático, envelhecimento ao ambiente marítimo, etc. (Berna, 1991). 
Envelhecimento Acelerado: envelhecimento realizado em condições tais que as durações das vidas úteis dos materiais se encurtam, como exposição em clima tórrido para materiais que não serão expostos a tais climas, ou algum dispositivo de concentração de radiação solar (Berna, 1991).

Envelhecimento Artificial: caso particular do envelhecimento acelerado, geralmente em câmaras de envelhecimento que simulam de modo mais ou menos fiel um clima natural, de maneira controlada, reprodutíveis (Berna, 1991).

As lâmpadas de arco de xenônio com filtro de vidro borossilicato são melhores que as lâmpadas de arco carbono ou que as fluorescentes (UVA e UVB) para simular o espectro total da luz solar (Searle; 1989).

Fatores que influem no envelhecimento natural são: radiação solar - UV, IR, raios X -, microrganismos, bactéria, fungos, alta umidade, ozônio, oxigênio, água: vapor, líquida ou sólida, energia térmica, poluição: química industrial (Berna, 1991).

As exposições à luz solar são feitas com a face do corpo de prova voltadas para o equador, em ângulos que variam de 0 a $90^{\circ}$, sendo os mais usuais, ângulos de $45^{\circ}$ (o mais utilizado); ângulo igual ao valor da latitude; ou da latitude menos $10^{\circ}$ (recomendada pela ASTM D1435), visando o maior tempo de exposição solar e maiores incidências de radiação durante o ano; $0^{\circ}$ e $90^{\circ}$ para produtos que ficarão nestas posições durante seu uso e $5^{\circ}$ para que simule a exposição de $0^{\circ}$ com alguma drenagem de chuva (Searle; 1989).

\subsubsection{Correlação e Previsão}

Alguns artigos indicam alguma correlação entre o envelhecimento artificial com o natural, como Baker (1995), que conseguiu a mesma degradação em XWOM com bem menos radiação que a exposição natural, provavelmente pelos raios serem mais seletivos e a temperatura dentro do aparelho se manter sempre elevada.

Para plásticos, é comum se elevar a temperatura para acelerar os testes de ensaios mecânicos dependentes do tempo.

Estudos envolvendo a correlação entre envelhecimento acelerado em 3 condições diferentes e exposição natural ao Sul da Flórida, EUA, de artigos têxteis de 
polipropileno, variando também suas massas e espessuras foram efetuados por Baker e Marienfeld, (Baker; Marienfeld, 1995).

No artigo de Delprat e Gardette (1993), envidenciou-se que o envelhecimento acelerado sob condições controladas pode prever a duração (vida útil) de materiais poliméricos por extrapolação. Fatores a serem levados em conta são difusão, permeabilidade e pressão de oxigênio e taxa de consumo de oxigênio; geometria do material, principalmente espessura; presença de aditivos e condições do envelhecimento acelerado.

Allan et al. (1993) fizeram uma modelagem matemática válida do envelhecimento acelerado para uma faixa definida de radiação utilizando-se filtros para controlar a faixa de radiação incidente nos corpos de prova.

Previsões mais confiáveis são obtidas pelo uso de uma equação de regressão linear como função do tempo em vez de simples fator médio (Searle; 1989).

Gijsman (1993), utilizando medidas das demandas de oxigênio contra resultados de degradação e elongação, demonstrou que os mecanismos de degradação nos envelhecimentos acelerado e natural são diferentes, apesar de muitas condições de ensaio já terem sido levadas em conta, com espectros de radiação e filtros.

A aceleração da degradação, tanto por fótons de mais alta energia, quanto por níveis excessivos de irradiação, podem alterar os mecanismos de degradação e levar a previsões de vida útil erradas (Searle; 1989).

White e Turnbull (1994) dizem, em sua revisão, que muitos exemplos na literatura demonstram que uma característica química, como o índice de carbonila, correlaciona razoavelmente bem com a deterioração das propriedades de engenharia, como a elongação na ruptura de um teste de tração.

Processos acelerados por aumento de temperatura podem promover processos de degradação que não ocorrem a temperaturas mais baixas (ambientes), inclusive a difusão de oxigênio pode ser suficientemente rápida, em temperaturas elevadas, para manter a reação. Deve-se ter atenção ao resfriamento por dispersão de água para simular chuva e a tensões geradas por gradientes de temperatura. Também para os ciclos dia/noite, já que a difusão de oxigênio, estabilizante e outros reagentes continua durante horas na escuridão, podendo ter comportamento diferente em uma simulação sem períodos escuros. 
White e Turnbull, em sua revisão de 1994, citaram que existe uma concordância generalizada que não há correlação perfeita entre envelhecimentos natural e artificial e que a correlação entre eles é inversamente proporcional ao grau de aceleração. É evidente que simplesmente conseguir o mesmo espectro na região do ultravioleta não é suficiente para obter uma boa correlação. A discussão sobre os mecanismos de degradação e estabilização evidencia a pobre correlação entre os envelhecimentos natural e artificial. Normalmente os estabilizantes funcionam melhor no envelhecimento natural que no artificial, devido à migração nos períodos de escuridão, recuperando algo da proteção do material.

Sobre a previsão do tempo de vida de polímeros envelhecidos, um dos objetivos do estudo da degradação e estabilização de polímeros é ser capaz de prever o seu tempo de vida útil baseado no conhecimento da composição do polímero, do ambiente e das tensões a serem encontradas. Nosso entendimento do efeito que uma pequena mudança na formulação pode causar no envelhecimento de um polímero é limitado e o envelhecimento acelerado é freqüentemente empregado para analisar as formulações. A questão mais comum é ser capaz de determinar um fator de aceleração entre um equipamento de exposição e o ambiente que o polímero encontrará, para se poder fazer a previsão de sua vida útil. Este objetivo tem sido o estímulo de estudos da cinética química da degradação de polímeros já que se um coeficiente possa ser determinado juntamente com a extensão crítica da reação para ocorrer fratura por uma tensão conhecida, a simples integração da equação da taxa de envelhecimento pode levar ao tempo de vida útil. Este modelo fica cada vez mais complexo quando os efeitos da difusão de oxigênio, oxidações heterogêneas em zonas localizadas e a dependência da intensidade da luz e temperatura de uma taxa de reação são levadas em conta (George, 1995).

\subsubsection{Mecanismos de degradação}

Até a perda de aditivos, como perda de plastificante por migração pode ser considerada como degradação, mas este estudo se deterá à série de reações químicas envolvendo inclusive ruptura das ligações da cadeia principal da macromolécula. 
A degradação pode ocorrer por causas físicas, como temperatura, esforços mecânicos, radiação eletromagnética (geralmente no ultravioleta) e radiação de alta energia; ou então por causas químicas, como oxidação, hidrólise (que pode causar quebra de cadeia em alguns polímeros, como náilon e policarbonato, como dizem White e Turnbull, em sua revisão de 1994), ozonólise, acidólise, etc.

Normalmente as causas ocorrem simultaneamente, sendo chamadas de termohidrolítica, termo-oxidativa, foto-oxidativa, etc.

$\mathrm{Na}$ quebra de cadeias, formam-se macro-radicais, muito reativos, resultando nas reações de ramificações, reticulações (pela proximidade de cadeias, uma cadeia acaba reagindo com outra, termofixando o polímero), redução na massa molar, despolimerização (Rabello, 2000).

Um dos mecanismos da foto-degradação pode formar duplas ligações no poliestireno, gerando reticulações que façam com que se aumente a massa molar (Trinh et al., 1994).

\subsubsection{Efeitos da degradação}

A degradação faz com que os polímeros sofram alterações nas propriedades reológicas, como diminuição da viscosidade, devido a diminuição de cadeias moleculares; perda de propriedades mecânicas; desenvolvimento de odor; alterações nos aspectos superficiais, como amarelamento, fissuramento, rachaduras, perda de brilho e perda de transparência.

A degradação só é desejada em processos de reciclagem, em materiais biodegradáveis, e durante a "mastigação" da borracha para a incorporação de aditivos com uma viscosidade menor (Rabello, 2000).

Descoloração, perda de transparência e brilho, fissuramento e rachaduras na superfície podem ocorrer antes das propriedades do corpo como um todo, como elongação, resistência à tração e características elétricas, serem significamente alteradas, embora algumas propriedades são dependentes do estado da superfície, como a resistência ao impacto, que é seriamente afetada por rachaduras na superfície (Searle; 1989). 


\subsubsection{Degradação Térmica}

Quando a energia térmica adicionada ao polímero é superior à energia das ligações intramoleculares na ausência de oxigênio, ocorre a degradação térmica, ruptura das ligações devido apenas à temperatura.

Cada polímero tem uma estabilidade térmica dependente da natureza dos grupos químicos presentes, que definem a energia de dissociação das ligações.

Não há uma correlação com a temperatura de fusão cristalina $\left(T_{m}\right)$, que depende da força de interação intermolecular.

As características térmicas do polímero são levadas em conta na hora da escolha do uso que se fará deste polímero, para que ele não amoleça no uso, e para que ele não degrade no processamento.

Algumas impurezas, como peróxidos ou hidroperóxidos (resíduos de síntese ou formados no armazenamento) são menos estáveis que o polímero e iniciam o processo degradativo via radicais livres (Rabello, 2000).

\subsubsection{Degradação termo-oxidativa}

É uma oxidação iniciada por processos térmicos, dependente de grupos químicos e ligações existentes na molécula.

Polímeros insaturados (como as borrachas) são facilmente oxidáveis, devido às ligações duplas.

O processo de oxidação de polímeros normalmente ocorre via radicais livres: (Rabello, 2000)

A iniciação envolve a clivagem homolítica (simétrica) de ligações covalentes, na cadeia principal ou não, ou devido a impurezas, como exemplificado na eq.2:

$$
P H \underset{\Delta}{\longrightarrow} P^{\bullet}+H^{\bullet}
$$

Propagação: $\quad P^{\bullet}+\mathrm{O}_{2} \longrightarrow \mathrm{POO}^{\bullet}$

$$
\mathrm{POO}^{\bullet}+\mathrm{P}^{\prime} \mathrm{H} \longrightarrow \mathrm{POOH}+\mathrm{P}^{\bullet}
$$


Ramificação:

$$
\begin{aligned}
& \mathrm{POOH} \longrightarrow \mathrm{PO}^{\bullet}+{ }^{\bullet} \mathrm{OH} \\
& 2 \mathrm{POOH} \longrightarrow \mathrm{POO}^{\bullet}+\mathrm{PO}^{\bullet}+\mathrm{H}_{2} \mathrm{O} \\
& \mathrm{PO}+\mathrm{PH} \longrightarrow \mathrm{POH}+\mathrm{P}^{\bullet} \\
& \mathrm{HO}^{\bullet}+\mathrm{PH} \longrightarrow \mathrm{P}^{\bullet}+\mathrm{H}_{2} \mathrm{O} \\
& \mathrm{POOH} \longrightarrow \mathrm{P}^{\bullet}+{ }^{\bullet} \mathrm{OOH} \\
& \mathrm{POOH}+\mathrm{P}^{\prime} \mathrm{H} \rightarrow \mathrm{PO}^{\bullet}+\mathrm{P}^{\prime \bullet}+\mathrm{H}_{2} \mathrm{O}
\end{aligned}
$$

A terminação da reação em cadeia ocorre pela reação de um par de radicais.

Mas nenhuma destas reações acima causa grandes perdas de propriedades de engenharia do material, pois as longas cadeias permanecem quase que inalteradas. A degradação ocorre porque os radicais são muito instáveis e podem levar a cisão de cadeias, como nos exemplos abaixo dados pelas equações eq. 14 e eq.15:

$$
\begin{aligned}
& P_{B}-P_{A}{ }_{C}-C_{P_{D}}^{\bullet}-\stackrel{\mid H}{C} H P_{C} \longrightarrow P_{A}^{\bullet}+P_{B} C H=\underset{P_{D}}{C} C H_{2} P_{C} \\
& P_{A}-\underset{P_{B}}{\stackrel{H}{C}}-O^{\bullet} \longrightarrow P_{A}^{\bullet}+P_{B} H C O
\end{aligned}
$$

(White; Turnbull, 1994)

Aditivos podem inibir a oxidação e íons metálicos podem catalisar a decomposição do polímero ou de hidroperóxidos presentes. Pequenas quantidades de íons metálicos, que podem estar presentes como resíduos de catalisadores, traços de metais da máquina de processamento, na superfície de cargas minerais ou como substrato de revestimento, podem provocar grandes efeitos degradativos, já que não são consumidos nesse processo. 


\subsubsection{Degradação foto-oxidativa}

O sol emite um espectro de radiação luminosa que vai do infravermelho, gerando calor, passando pelo espectro de luz visível, até o ultravioleta, causando reações químicas, geralmente iniciadas por radicais livres, gerando a degradação de materiais.

Sussman (2000) explica que o espectro eletromagnético, incluindo rádio, radar e microondas, infravermelho, luz visível, UV, Raios X, Raios Gama, todas estas formas de energia viajam à velocidade da luz e se deslocam como onda, sem que esta energia se perca enquanto viajam (mesmo em distâncias imensas, como do Sol até a Terra). A diferença entre elas é o comprimento de onda, ou a freqüência, inversamente proporcional ao comprimento de onda. O comprimento de onda dos raios $\mathrm{X}$ é cerca de mil vezes mais curto que o da luz visível (verde, por exemplo), enquanto o das ondas de rádio é em torno de mil vezes mais longo que o da luz verde. Este espectro, isto é, uma extensa faixa de um bilhão de vezes no tamanho de seus comprimentos de onda. O sol não é monótono; ele irradia energia numa faixa bastante ampla de comprimentos de onda. O sol irradia cerca de metade de sua energia na parte visível do espectro eletromagnético e $40 \%$ de sua energia na região infravermelha (mais longa do que os comprimentos de onda do vermelho, que alguns animais, como as cascavéis, podem ver) e em torno de $10 \%$ de sua radiação como raios ultravioleta (mais curtos do que o violeta, que alguns animais, como as abelhas, podem ver).

A radiação ultravioleta (comprimento de onda entre 100 e $400 \mathrm{~nm}$, correspondente a cerca de $5 \%$ da radiação solar) é uma das principais fontes causadoras da degradação de polímeros. Parte da radiação é filtrada pela camada de ozônio e outros constituintes da atmosfera, eliminando raios menores que $\lambda=290 \mathrm{~nm}$ (Rabello, 2000).

Quando há a absorção desta radiação por grupos específicos do polímero, aumenta a excitação eletrônica, que pode resultar em cisão molecular, formando radicais livres. Na presença de oxigênio, a propagação ocorre como na termo-oxidação (apresentada no item anterior).

A reação de iniciação da foto-oxidação é do tipo: 


$$
\text { polímero } \stackrel{U V}{\longrightarrow} \text { estado excitado } \longrightarrow \text { radicais livres }
$$

Alguns polímeros, como as poliolefinas $\mathrm{PP}$ e PE, absorvem fortemente a radiação UV em comprimentos de onda menores que $250 \mathrm{~nm}$, inferior aos raios que atingem a superfície terrestre $(290 \mathrm{~nm})$ e, apesar disso, são altamente suscetíveis à fotodegradação. A explicação mais aceita é que hidroperóxidos e carbonilas (gerados no processamento ou na síntese), pigmentos, cargas, lubrificantes ou plastificantes atuem como iniciadores da foto-degradação, chamados de cromóforos (Rabello, 2000).

No caso do poliestireno, a absorção da luz de comprimento de onda menor que 300 $\mathrm{nm}$ resulta na formação de singletes em estado excitado nos grupos fenil:

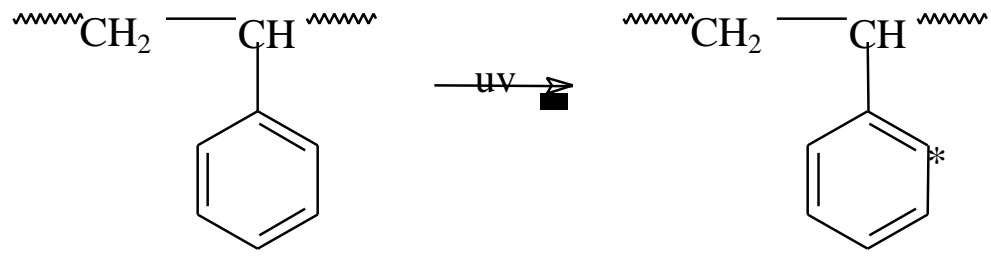

Este estado eletronicamente excitado pode ser detectado por métodos de luminescência (fluorescência e fosforescência) e por absorção de luz.

O Poliestireno degrada também por foto-irradiação de luz com comprimentos de onda maiores que $300 \mathrm{~nm}$, pelos seus grupos terminais e ocasionalmente por alguma impureza incorporada (Torikai, 1989).

Foi determinada a faixa de sensibilidade à radiação ultravioleta do SBS e comparouse com a do PS. A conclusão do trabalho foi que o polibutadieno degrada muito mais rapidamente que o poliestireno (Xingzhou; Zubo, 1995).

O polibutadieno é mais susceptível à radiação UV com $\lambda>300 \mathrm{~nm}$ que o poliestireno, inclusive a degradação iniciada pelo polibutadieno ataca o poliestireno que normalmente não degradaria (Piton; Rivaton, 1997).

Stevens (1992) compara o uso de polibutadieno, que é um polímero insaturado, susceptível a UV, contra borrachas saturadas, menos susceptíveis à degradação, no poliestireno e os efeitos do envelhecimento nas propriedades de ambas. Como o custo dessas borrachas saturadas especiais é alto, a co-extrusão com material 
fabricado com a borracha comum é usual, para que o uso da borracha especial proteja a superfície (Stevens, 1992).

Em muitos polímeros, a oxidação é induzida por impurezas cromóforas, que não podem ser removidas dos polímeros. Para irradiação ultravioleta curta, o anel aromático absorve a luz, enquanto os agentes cromóforos podem iniciar a degradação para irradiações ultravioletas longas (Mailhot; Jarroux; Gardette, 2000).

A foto-degradação por radicais livres pode iniciar-se tanto por dissociação causada pela colisão de um fóton com energia suficiente na molécula polimérica, ou pela presença de alguma impureza (cromóforos), por exemplo, traços de metais de catalisador de polimerização (White; Turnbull, 1994).

Zweifel (1993) publicou que as impurezas podem ser estabilizantes aromáticos para prevenir degradação durante o processamento, metais de transição, catalisadores de Ziegler-Natta e pigmentos e que a poluição atmosférica pode contribuir com a formação de componentes ou grupos cromóforos que absorvem a luz do sol (Zweifeil, 1993).

O início e a taxa da degradação são influenciados pelas condições de polimerização, como temperatura e impurezas da reação (Weir; Whiting; 1989).

Salman comparou a degradação de HIPS virgem com HIPS reciclados, fazendo posterior foto-degradação com xenônio. Concuiu que quanto mais reciclada a amostra, maior a taxa de degradação observada (Salman, 1993).

A foto-degradação é importante devido ao crescente uso dos polímeros em ambientes externos.

\subsubsection{Velocidade de foto-degradação}

A velocidade de foto-degradação depende dos fatores ambientais, como a temperatura e a intensidade e composição espectral da radiação solar UV (Rabello, 2000).

O poliestireno degrada em temperatura elevada (perto de $300^{\circ} \mathrm{C}$ ). Pouco antes de $300^{\circ} \mathrm{C}$ a degradação não envolve a formação de voláteis, mas acima de $300^{\circ} \mathrm{C}$ formase uma mistura de estireno, tolueno, metil estireno e outros produtos. 
A reação de foto-oxidação para alguns polímeros é dependente da dose de radiação, então testes acelerados não podem ser usados para prever tempo de vida, sendo apenas capazes de determinar desempenhos relativos (George, 1995).

A dose de radiação e a temperatura agem sinergicamente promovendo a degradação, isto é, o efeito das duas causas juntas é maior que a soma delas agindo separadamente (White; Turnbull, 1994).

Outros fatores que influenciam a velocidade da degradação são a umidade e outros componentes atmosféricos (Rabello, 2000).

Ataque de poluentes, que podem ser fotolíticos, levando a outros produtos que podem causar degradação, por exemplo, o $\mathrm{SO}_{2}$ foto-oxida e reage com água, produzindo $\mathrm{H}_{2} \mathrm{SO}_{4}$ (White; Turnbull, 1994).

As estruturas química e física do polímero indicam sensibilidade espectral, taxa de difusão de oxigênio e de outras espécies reativas, reatividade, etc.

$\mathrm{Na}$ síntese dos polímeros pode haver resíduos de catalisadores e outros grupos cromóforos e, como White e Turnbull (1994) colocaram, a degradação molecular que ocorre durante a fabricação pode deixar o polímero mais vulnerável a danos posteriores, por exemplo durante o envelhecimento.

A degradação oxidativa anterior, grupos cromóforos e a composição contendo aditivos foto-sensíveis ou inibidores da foto-oxidação, influenciam a velocidade da degradação (Rabello, 2000).

Agentes estabilizantes de ultravioleta que possam ser copolimerizados evitam problemas como incompatibilidade, volatilidade e migração do estabilizante para a superfície, devido a ligações covalentes (Konstantinova et al., 1994). Pittolo e Burford (Pittolo; Burford, 1986) encontraram resultados similares. A revisão de White e Turnbull (White; Turnbull, 1994) comenta também sobre este tema, complementando que a copolimerização do estabilizante com o monômero pode causar mudanças indesejáveis nas propriedades do material e que um acoplamento posterior por enxerto promove estabilização mais efetiva.

A copolimerização do estabilizante com o monômero pode causar mudanças indesejáveis nas propriedades do material e um acoplamento posterior por enxerto promove estabilização mais efetiva (White; Turnbull, 1994). 
Torikai constatou que agentes anti-chama pioram a resistência a UV (Torikai et al., 1993).

A Thermofil mostrou comercialmente um produto que contém um agente retardante de chama que promove também estabilidade térmica, mas não a UV, pois necessita de um outro agente específico esta característica (Thermofil, 1991).

\subsubsection{Perfil de degradação}

A transmissão de radiação UV através de amostras espessas define o perfil de degradação (Rabello, 2000).

A degradação foto-química ocorre preferencialmente perto da superfície do polímero exposta a temperatura elevada e altos níveis de radiação ultravioleta (O’Donnell; White, 1993).

A degradação foto-oxidativa começa na superfície do polímero e as microrachaduras formadas podem propagar-se através do material não oxidado, inclusive dúctil, quando submetido a tensão externa (Zweifeil, 1993).

A maioria dos polímeros tem sua superfície fragilizada durante a exposição externa e o ataque preferencial é em irregularidades, incluindo cromóforos, que pode levar a concentração de tensões e a formação de micro-rachaduras. A aplicação de camadas frágeis de polímeros vítreos em polímeros modificados por borracha causa redução de resistência ao impacto, como por exemplo camada de poliestireno sobre poliestireno de alto impacto ou ABS (acrilonitrila-butadieno-estireno) (White; Turnbull, 1994).

Aditivos absorvedores de UV transparentes à luz visível não alteram a aparência do produto. Exemplos: hidroxibenzofenonas, hidroxifenilbenzotriazolas, hidroxifeniltriazinas e derivados de salicilatos fenílicos. Assim como nos bloqueadores de luz, os absorvedores de UV fazem com que a radiação deste tipo vá diminuindo rapidamente enquanto vai penetrando no material e a degradação é concentrada ainda mais na superfície. Seria portanto economicamente significativo se estes aditivos pudessem ser concentrados na superfície. Em alguns casos, a combinação de dois diferentes anti-oxidantes promove melhor proteção que o 
previsto por simples soma dos efeitos produzidos por eles separadamente, um fenômeno conhecido como sinergia (White; Turnbull, 1994).

Faucitano, et al. (1996) fizeram uma revisão de literatura, mencionando mecanismos, sobre a inibição da foto-oxidação (estabilizantes). A iniciação da foto-oxidação do poliestireno e de plásticos baseados em poliestireno ocorre principalmente por cetonas aromáticas do tipo acetofenona, formadas durante o processamento em alta temperatura. Cetonas em estado de triplete podem separar hidrogênios de grupos benzilas e decompor os hidroperóxidos por transferência de energia. A maior rota de propagação na foto-oxidação é a hidroperoxidação baseada na separação do hidrogênio no carbono adjacente ao anel aromático, levando à formação de hidroperóxidos terciários, álcoois terciários e acetofenonas. A proteção contra fotooxidação é alcançada pelo uso de uma combinação de estabilizantes, os mais promissores sendo absorvedor de UV do tipo benzotriazola acoplado com o estabilizante HALS. Esta combinação foi provada ser muito eficiente também para ABS, onde a taxa do processo oxidativo é maior devido a presença de resíduos de grupos vinila do dieno.

Para muitos materiais, a taxa de degradação é inicialmente alta e diminui ao longo da exposição. Isto resulta da diminuição das espécies foto-ativas e da formação de fotoprodutos absorvedores de ultravioleta, que bloqueiam a radiação do polímero (Searle; 1989).

\subsubsection{Influência da morfologia na foto-degradação}

Se uma ligação química recebe tensão suficiente, ela quebrará. Não é fácil aplicar tal tensão, pois o mecanismo de deformação intervém. Para que isto ocorra, a ligação da cadeia polimérica a ser quebrada deve estar estendida entre os emaranhados moleculares ou reticulações e não deve escorregar. Normalmente o que ocorre é uma ajuda da tensão para quebrar a ligação, uma degradação mecânico-química (White; Turnbull, 1994). 
A tensão em tração acelera a degradação molecular causada por reação foto-química, levando geralmente à diminuição nos valores das propriedades de engenharia (O’Donnell; White, 1993).

Os rearranjos das ligações necessárias na reação de oxidação são mais facilmente atingidos em moléculas "enroladas", então polímeros orientados oxidam mais lentamente. A difusão de oxigênio é geralmente menor em um polímero orientado, assim como a difusão de estabilizantes.

Tensões em tração geralmente aceleram a degradação, enquanto tensões em compressão a retardam.

Em relação à morfologia no processamento, a temperatura necessária para promover determinada propriedade de escoamento para uma operação de injeção pode ser alta suficiente para promover degradação significante, especialmente se oxigênio estiver presente, mais a influência das forças do processamento, causam cisões mecânicoquímicas, ou seja, degradação química auxiliada por tensão.

As reações de degradação ocorrem quase que exclusivamente na fase amorfa, porque a tomada de oxigênio é muito mais instantânea que na fase cristalina. Talvez ocorra preferencialmente na divisa entre as regiões amorfa e cristalina. A orientação molecular é outra característica morfológica, ocorrendo tanto na região cristalina ou amorfa. A foto-degradação é mais lenta em polímeros orientados (White; Turnbull, 1994).

$\mathrm{Na}$ prática, muitos polímeros são usados no ambiente externo sob tensão ou eles próprios têm tensões internas como consequiência do processo de moldagem, em que a taxa de resfriamento resulta em uma mudança gradual tanto em volume livre quanto em morfologia, da superfície para o centro. É relatado que o poliestireno demonstra uma rápida perda na resistência à tração quando tracionado em $20 \%$ de seu limite (numa comparação de duas semanas, o poliestireno exposto com tensão perdeu $40 \%$ da propriedade, enquanto o poliestireno exposto naturalmente perdeu 4\%) (George, 1995). 


\subsubsection{Difusão de oxigênio}

A degradação oxidativa depende da concentração de oxigênio. Em filmes (até cerca de $50 \mu \mathrm{m}$ de espessura), a cinética da degradação é determinada pela velocidade de reação, pois há oxigênio em abundância. Para materiais mais espessos, as reações podem se restringir à superfície da peça, já que o oxigênio é consumido rapidamente durante sua difusão para o interior do produto. O perfil de degradação é muito importante na definição do comportamento mecânico e do mecanismo de fratura dos polímeros degradados (Rabello, 2000).

A taxa de cisão das cadeias na foto-degradação do poliestireno é maior que a de reticulação em todo o perfil do corpo de prova exposto. A taxa de reticulação é maior na superfície exposta e a da superfície não exposta é maior que no centro do corpo de prova. A alta taxa de produção de radicais tem um efeito na formação de reticulação maior que na taxa de cisão de cadeia (Shyichuk; White, 2000).

O perfil da degradação do PS e de outros polímeros, como PP e GFPP, indica que no meio do corpo de prova a degradação é menor que na face não-exposta (O'Donnell; White; Hollding, 1994).

A Figura 1 mostra a degradação limitada pela difusão de oxigênio, no perfil de degradação de um corpo de prova.

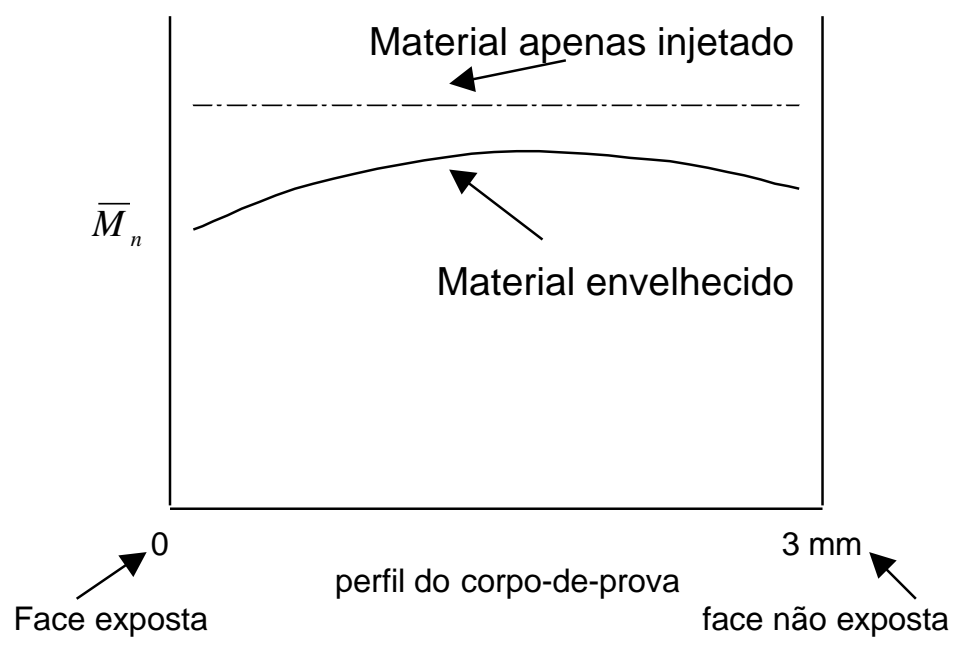

Figura 1: Média Molar Numérica em relação à profundidade de corpo de prova de poliestireno, adaptado de O’Donnell; White; Hollding (1994) em escala qualitativa. 
Mailhot e Gardette (1992a e 1992b) numa investigação profunda sobre os produtos formados da foto-degradação revelaram que muitos destes produtos são moléculas simples, várias delas identificadas: benzaldeído, ácido benzóico, acetofenona, ácido fórmico, ácido acético, anidrido benzóico, dibenzoilmetano e benzeno. Eles propuseram um mecanismo geral para a foto-degradação do poliestireno. 


\subsection{Avaliações dos Polímeros}

\subsubsection{Determinação da estrutura química}

A Espectroscopia no Infravermelho com Transformada de Fourier (FTIR) envolve Absorção de energia com raios infravermelho. Usado para descobrir grupos funcionais: $-\mathrm{CH},-\mathrm{CO},-\mathrm{CH}_{3}$ Existem dois tipos: infravermelho fundamental (IR) e infravermelho próximo (NIR), este último representa as ondas harmônicas do primeiro, sendo que o equipamento permite a análise de peças espessas e até inteiras, enquanto que para análise no infravermelho fundamental é necessária a confecção de filmes do material (Fried, 1995)

"A região do infravermelho próximo (NIR), como definida pela IUPAC, se estende de 780 a $2500 \mathrm{~nm}$. O espectro NIR é constituído de bandas de absorção devido às harmônicas e combinações das vibrações de estiramento e de deformação angular observadas no infravermelho médio (MIR), de moléculas contendo grupos do tipo XH, onde X é igual a C, O, N e S.” (Araújo et al., 1999, p. 565)

Já a Espectroscopia Raman, funciona com espalhamento de energia com raio laser. Como o material não absorve a energia, podem ser utilizadas peças inteiras para análise. A molécula devolve inelasticamente a energia num nível diferente. Essa técnica é usada no estudo da morfologia do polímero, especialmente no estudo da estrutura cristalina e efeitos de orientação.

A Espectroscopia de Ressonância Magnética Nuclear (NMR) é usada para determinar a estrutura molecular de materiais desconhecidos, taticidade, ramificações, defeitos estruturais, a sequiência de unidades de comonômeros na cadeia copolimérica, e alterações químicas como estados de oxidação, que podem ser detectados em 1 a cada 500 unidades repetitivas. Núcleos utilizados: ${ }^{13} \mathrm{C},{ }^{1} \mathrm{H},{ }^{17} \mathrm{O},{ }^{19} \mathrm{~F}$ (fluorpolímeros), ${ }^{29} \mathrm{Si}$ (polisiloxanas), ${ }^{15} \mathrm{~N}$ (poliamidas), ${ }^{31} \mathrm{P}$ (polifosfazenas). A técnica de relaxação de prótons (uma método de NMR tipo banda-larga) pode ser usada para determinar o conteúdo amorfo e orientação de cadeia em polímeros semicristalinos. Medidas de NMR de alta energia podem ser usadas para obter informação sobre a seqüência de unidades repetitivas na cadeia, conseqüentemente a determinação da taticidade e distribuição comonomérica (Fried, 1995). 


\subsubsection{Mecanismos de Deformação}

Em pequenas elongações $(<1 \%)$, a maioria dos polímeros é elástica, podendo retornar completa e homogeneamente ao estado inicial num tempo finito. Em elongações maiores, polímeros frágeis podem apresentar fissuras (crazing) e polímeros dúcteis podem formar bandas de cisalhamento, que se desenvolvem a $45^{\circ}$ da direção de estiramento.

\subsubsection{Teste estático}

Neste tipo de teste, a taxa de deformação é constante ao longo do tempo. O teste de elongação (tração) é o mais comum, além do de compressão e cisalhamento. A figura 2 exemplifica um ensaio de tração:

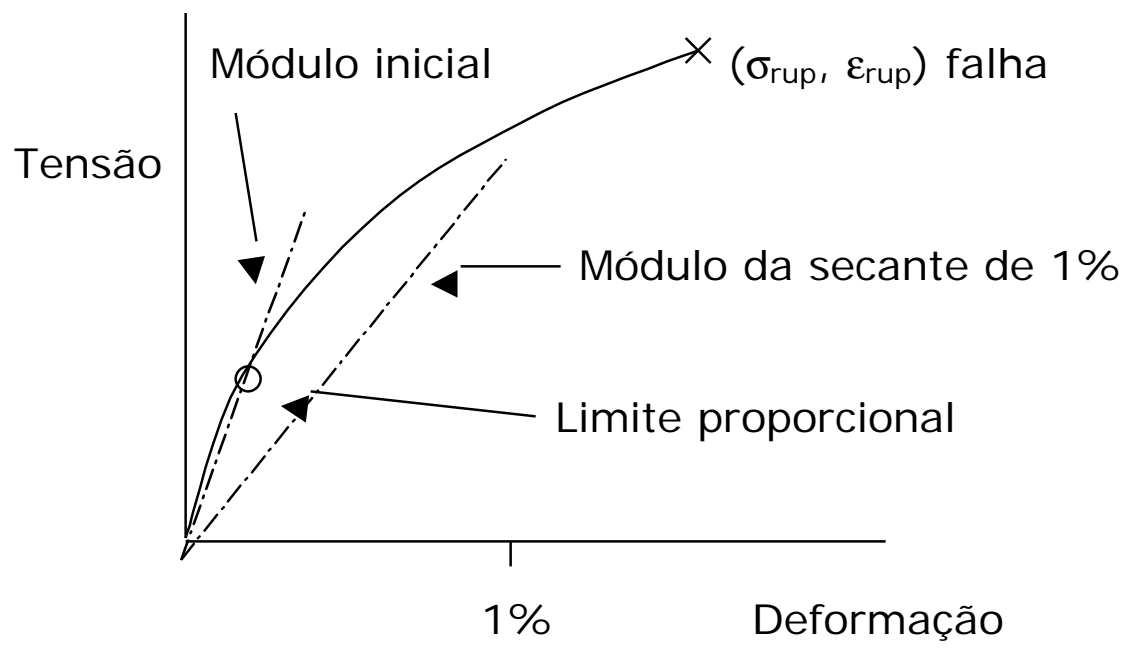

Figura 2: Exemplo de curva de ensaio de tração de polímeros, adaptado de Fried (1995).

O teste de tração mais comum é o teste de carregamento monotônico conduzido sob velocidade constante de afastamento. Todos os dados do teste devem ser registrados, mas o desempenho é usualmente julgado com referência à tensão máxima (de engenharia) durante o teste e a elongação na ruptura. É possível que se derive o Módulo de Young, mas sua precisão é limitada, ao menos que se use um 
extensômetro e ele será uma média de toda a seção transversal (White; Turnbull, 1994).

As propriedades mecânicas podem aumentar e diminuir ao longo do envelhecimento, resultado de degradação ou relaxação de tensão nas amostras moldadas por injeção (Sanchez; Ferreira; Felisberti; 1999).

Eventuais aumentos de resistência nas propriedades mecânicas nos primeiros momentos do envelhecimento podem ser explicados por reticulações, seguidos por cisões (Sanchez; Felisberti, 1999).

É presumido que uma recuperação parcial da degradação ocorre quando a camada superficial torna-se tão fraca que não consegue transmitir tensão para o interior quando o material é tracionado (White; Turnbull, 1994).

O teste de tração é a base para comparação do grau de envelhecimento de polímeros e é observado que o método de processamento e preparação do corpo de prova para tração pode afetar o envelhecimento posterior. Amostras moldadas por injeção terão um grau de orientação dependente das condições de moldagem e terão uma "pele" na superfície, que terá uma espessura e orientação variando de acordo com a produção. As medidas foram feitas com amostras preparadas com micrótomo em seções de 10 $\mu \mathrm{m}$ (George, 1995).

A elongação na falha é a propriedade mais sensível para indicar os efeitos do intemperismo em polímeros dúcteis, variando de poliamidas semicristalinas e poliolefinas a policarbonato amorfo, enquanto em polímeros frágeis como poliestireno, as mudanças na tensão em tração podem prover um melhor indicador de degradação (George, 1995).

\subsubsection{Teste transiente}

A fluência (creep) é quando se deixa deformar o material sob uma carga constante e a tensão-relaxação é a tensão necessária para manter um corpo de prova numa elongação constante numa dada temperatura. A fluência pode ser realizada em cisalhamento, torção, flexão, compressão e em tração (Fried, 1995). 


\subsubsection{Teste de impacto}

Os mais usados são o IZOD (corpo de prova posicionado na vertical, preso na máquina apenas por uma extremidade) e o Charpy (corpo de prova posicionado na horinzontal, preso no equipamento pelas duas extremidades), onde a resistência ao impacto é medida através da perda de energia de um martelo ao quebrar o corpo de prova. Um entalhe direciona o início da quebra do material. Materiais frágeis podem ter sua resistência ao impacto melhorada pela adição de borracha na matriz polimérica, como o poliestireno alto impacto (HIPS) e a resina ABS (Fried, 1995).

Os polímeros moldados por injeção contêm uma "pele" na superfície, da ordem de 0,2 a $0,4 \mathrm{~mm}$ de espessura, que tem propriedades muito diferentes às do interior. A ação de entalhar o corpo de prova, expõe o núcleo do corpo de prova, que tem resistência a intempéries diferente da camada superficial. Além disto, a "pele" é normalmente uma região de tensão residual de compressão, que diminui a propagação de rachaduras, enquanto a raiz do entalhe é localizada em uma região de tensão mais fraca, possivelmente em tração, portanto muita cautela deve ser utilizada neste tipo de procedimento. White e Turnbull comentam sobre o efeito do entalhe ser feito após o material ser degradado, fazendo com que a região da rachadura ocorra em uma posição que não seria a ocorrida naturalmente (White; Turnbull, 1994).

Propriedades de impacto são de grande significado prático, já que são sensíveis a quaisquer imperfeições de superfície. $\mathrm{O}$ interior de um corpo de prova injetado tem propriedades diferentes da "pele" parcialmente orientada, que é submetida ao tempo (George, 1995).

\subsubsection{Avaliação da degradação}

Os efeitos da degradação podem ser avaliados através de 3 grupos de caracterização: 


\subsubsection{Quantificação da degradação química}

\subsection{Massa molar}

A determinação das massas molares por viscosimetria; GPC, ou um método indireto como o índice de fluidez, em que seu aumento indica diminuição na massa molar, permitem observar as conseqüências de uma degradação química, com quebras de cadeias ou reticulações.

Normalmente, há um deslocamento da distribuição molar para valores menores, indicando que a degradação inclui mecanismos de quebra de cadeia (O'Donnell; White; Hollding, 1994).

Sobre a massa molar, quando um polímero amorfo é processado no estado fundido, ele consiste em uma rede enrolada de cadeias poliméricas. Quanto mais longas as cadeias, maiores serão os emaranhados. Quando o material é submetido a uma força, a resposta dependerá de quanto as cadeias poderão se desenrolar, ou possivelmente, romper-se. Como o processo de polimerização produz cadeias de comprimentos variáveis, é necessário medir a distribuição por uma técnica cromatográfica ou fracionária e a largura da distribuição pode ser julgada pela polidispersão. A viscosidade aumenta rapidamente com o tamanho de cadeia, a massa molar de muitos polímeros é controlada para não chegar no tamanho crítico, onde a viscosidade não aumenta mais na mesma razão com o tamanho da cadeia. Conseqüentemente, qualquer diminuição na massa molar leva a uma queda imediata da força (George, 1995).

\subsection{Composição química}

A determinação da composição química por métodos analíticos e por espectroscopia na região do infravermelho pode indicar o grau de degradação de um polímero.

A presença de grupos carbonila num polímero degradado indica que houve oxidação e avisa que o material está vulnerável a maior degradação, pois são foto-lábeis (White; Turnbull, 1994). 
A análise por Infravermelho com Transformada de Fourier onde se acopla um elemento ótico de Refletância Total Atenuada (ATR, Attenuated Total Reflectance) resulta na análise apenas dos primeiros $0,3 \mu \mathrm{m}$ a $10 \mu \mathrm{m}$ da superfície do polímero, podendo-se estudar o perfil de degradação na profundidade da amostra fazendo-se variar o índice de refração do elemento de ATR com o ângulo de incidência da radiação infravermelha. A medida da concentração de produtos de oxidação por FTIR na região da carbonila (1850 a $\left.1650 \mathrm{~cm}^{-1}\right)$ mostra o perfil de degradação com o tempo ou com a profundidade (camadas retiradas por micrótomo) (George, 1995).

A absorção de oxigênio pode ser medida para determinar a velocidade de oxidação (Rabello, 2000).

\subsubsection{Avaliação das propriedades físicas}

\subsection{Comportamento mecânico}

O comportamento mecânico, como alongamento, resistências à tração e ao impacto, permite avaliar a degradação de polímeros.

\subsection{Aparência superficial}

A aparência pode ser uma característica essencial para artigos plásticos, que, quando degradados, podem ter perdas de transparência e brilho, amarelamento, fissuramento, etc., prejudicando assim sua vida útil.

O microscópio do tipo SEM é uma técnica plausível para o estudo de mudanças na morfologia causada por foto-degradação, pois a irradiação ultravioleta tem ação localizada na superfície dos polímeros (Haczmarek, 1996). 


\subsection{Outras propriedades}

A depender da aplicação, outras propriedades podem ser medidas, como por exemplo, propriedades térmicas ou elétricas, verificando sua estabilidade perante a degradação.

\subsubsection{Métodos térmicos}

A análise termogravimétrica, em que a perda de massa depende da quantidade de degradação e DSC, para determinação de temperatura de fusão e/ou de transição vítrea e temperatura de decomposição, são métodos em que se avalia a influência da temperatura nas estruturas do material.

Fatores secundários que podem alterar a $T_{g}$ incluem o tamanho molecular, o grau de reticulação e concentração de plastificante (quando for o caso). Cisão de cadeia cria mais terminais de cadeia livres, diminuindo a $T_{g}$; aumentando a densidade de reticulação aumenta $T_{g}$ e uma diminuição na concentração de plastificante, por difusão ou volatilização, causa um aumento na $T_{g}$. Todos estes efeitos alteram com a distância da superfície e as medições mais significativas são feitas usando-se amostras de bandas estreitas em profundidades definidas, retiradas com muito cuidado no procedimento e análise. A $T_{g}$ de PVC e de poliestireno diminuíram em $20^{\circ} \mathrm{C}$ após um ano de exposição externa na Arábia Saudita (White; Turnbull, 1994).

\subsubsection{Escolha do método}

A escolha de um determinado método é ditada pela aplicação a que o produto estará sujeito, disponibilidade de instrumentação e pelo tipo de polímero. Por exemplo, para formulações para estabilização térmica durante o processamento, extrusões sucessivas e avaliação do índice de fluidez é uma metodologia simples e eficaz. 
Para a simulação de termo-degradação, uma estufa com circulação forçada de ar em temperaturas abaixo do ponto de amolecimento do material pode simular seus efeitos. Neste caso é melhor utilizar temperaturas perto da temperatura de uso do material para evitar erros de extrapolação.

A foto-degradação pode ser avaliada por exposição natural ou artificial. A exposição natural tem a vantagem de estar diretamente relacionada com as condições reais de serviço, mas apresenta algumas desvantagens, como lentidão e impossibilidade de reproduzir as mesmas condições. O envelhecimento artificial é realizado por meio de fontes de radiação UV, com lâmpadas fluorescentes especiais, como arcos de xenônio, lâmpadas de vapor de mercúrio, etc., em bancada ou em câmaras de intemperismo do tipo WOM, que simulam condições ambientais como umidade, chuvas, poluentes, descargas elétricas, variações noite/dia, etc. As vantagens do envelhecimento artificial são rapidez e reprodutibilidade do ensaio e sua grande desvantagem é a dificuldade de correlacionar os dados obtidos com as condições naturais, além da não uniformidade de exposição em diferentes locais da peça, diminuição na emissão de UV com o tempo de uso, maior custo, limitação de espaço físico, etc. (Rabello, 2000). 


\section{Materiais e Métodos}

\subsection{Materiais e Equipamentos}

\subsubsection{Materiais}

Os polímeros PS (GPPS Polystyrol 144 C) e PSAI copolímero (HIPS Polystyrol 466 N) granulados foram fornecidos pela BASF S.A., apresentando as seguintes características típicas:

PS: resistência à tração (tensão na ruptura) de $42 \mathrm{MPa}$; elongação na ruptura de 1,5\%; módulo de elasticidade em tração de $3300 \mathrm{MPa}$; tensão máxima em flexão de $68 \mathrm{MPa}$; dureza de identificação de bola H 358/30 de $150 \mathrm{MPa}$; resistência ao impacto Charpy sem entalhe de $10 \mathrm{~kJ} / \mathrm{m}^{2}$; índice de fluidez volumétrica de 28 $\mathrm{mL} / 10 \mathrm{~min}$; ponto de amolecimento VICAT A/120 de $92^{\circ} \mathrm{C}$; temperatura de deflexão sob carga de $70^{\circ} \mathrm{C}$; massa específica de $1,05 \mathrm{~g} / \mathrm{cm}^{3}$ e absorção de água de $<0,1 \%$; constante dielétrica de 2,5; resistividade volumétrica de $10^{16} \Omega . \mathrm{cm}$; resistividade na superfície de $10^{14} \Omega$ e força dielétrica de $135 \mathrm{kV} / \mathrm{mm}$.

PSAI: resistência à tração (tensão na ruptura) de 3400 psi; elongação na ruptura de 40\%; módulo de elasticidade em tração de 290000 psi; dureza Rockwell 50 L; resistência ao impacto IZOD de 2,2 pé.lbf/pol entalhe; índice de fluidez de 2,6 g/10min; ponto de amolecimento VICAT de $102^{\circ} \mathrm{C}$; temperatura de deflexão sob carga de $92^{\circ} \mathrm{C}$; massa específica de $1,06 \mathrm{~g} / \mathrm{cm}^{3}$ e absorção de água de $0,07 \%$.

\subsubsection{Equipamentos}

\subsubsection{Injeção}

Foi utilizada uma injetora Battenfeld 1980, capacidade de fechamento de 35 toneladas, capacidade de injeção de 100 g, da unidade em São José dos Campos, São Paulo, da BASF S.A.. 


\subsubsection{Câmara de Intemperismo Artificial}

Foi utilizado um aparelho de intemperismo modelo 65 WRC, identificação WOM001, tipo Weather-o-Meter, do IPT, com lâmpada de arco-xenônio, de potência $6500 \mathrm{~W}$, com filtros interno e externo de vidro borossilicato.

\subsubsection{Estação de Envelhecimento Natural}

Foi utilizada a Estação de Envelhecimento Natural do IPT, que consiste de uma série de suportes para corpos de prova voltados para o norte, em um ângulo de $45^{\circ} \mathrm{com}$ a horizontal, localizada na latitude: $23^{\circ} 34^{\prime}$ e longitude: $46^{\circ} 44^{\prime}$.

\subsubsection{Ensaio de Tração}

Foi utilizada uma máquina universal de ensaios da marca Emic, identificação MUE001, com certificado de calibração 32441 do Laboratório de Metrologia/AMAEI/DME do IPT, calibrado em 05/11/1999, com validade até $05 / 11 / 2000$.

Paquímetro pequeno digital (faixa nominal $150 \mathrm{~mm}$ ), identificação PA-004, com certificado de calibração 32504 do Laboratório de Metrologia/AMAEI/DME do IPT, calibrado em 17/11/1999, com validade até 17/11/2000.

Cronômetro digital de identificação CR-001, com certificado de calibração R0272/2000 da Balitek Instrumentos e Serviços Ltda., Laboratório Padrão, credenciado pelo INMETRO sob $\mathrm{n}^{\circ} 053$ e 097, calibrado em 10/04/2000, com validade até 10/04/2002.

Termohigrômetro marca Homis, identificação TH-003, com certificado de calibração 34445 do Laboratório de Vazão/LV/DME do IPT, calibrado em 25/04/2000, válido até $25 / 04 / 2001$.

Foi utilizado um Scanner, marca Hewlett Packard, modelo Scanjet 3200C. 


\subsubsection{Calorimetria Exploratória Diferencial (DSC)}

Foram utilizados para o ensaio de DSC um calorímetro Shimadzu DSC-50, tipo Differential Scanning Calorimeter, com interface Shimadzu TA-50I Thermal Analyzer; nitrogênio White Martins; panelas de alumínio com tampa Shimadzu 20152943; aparelho para fechar panela Shimadzu, modelo SSC-30, n F200801405, todos do Laboratório de Análise Térmica do IPEN.

A calibração foi realizada com amostras com elementos índio e chumbo para correção de ponto de fusão e entalpia.

A rampa de aquecimento utilizada em todos os ensaios foi de $10^{\circ} \mathrm{C} / \mathrm{min}$ a partir da temperatura ambiente, ou de pelo menos abaixo de $40^{\circ} \mathrm{C}$ quando da segunda corrida, com vazão de $50 \mathrm{~mL} / \mathrm{min}$ de nitrogênio.

\subsubsection{Resistência ao impacto}

Foi utilizado um aparelho de impacto analógico, marca Zwich, ano 1967, identificação IM-002, faixa nominal máxima da energia do martelo $40 \mathrm{kcpm}$ ou 3,9J, divisão da escala 0,05 para 0-5 kpcm, 0,1 para 0-10 kpcm e 0,2 para 0-40 kpcm, calibrado antes do uso por ajuste no pêndulo, com o martelo em vazio.

\subsubsection{7. Índice de fluidez}

Foi utilizado um aparelho de índice de fluidez marca Wallace, identificação AIF-001, tipo analógico, com valor de uma divisão 0,125 in.lbf ou 2 in.oz, calibrado antes do uso por medição da temperatura por termômetro de líquido (mercúrio) em vidro identificação TE-009, marca Incoterm, modelo ASTM 2C, tipo analógico e imersão parcial, faixa nominal $-5^{\circ} \mathrm{C}$ a $300^{\circ} \mathrm{C}$, divisão de $1^{\circ} \mathrm{C}$, escala externa, com erro de \pm $0,2^{\circ} \mathrm{C}$, calibrado em $25 / 07 / 2001$, com validade até 25/07/2005. 


\subsection{Metodologia}

Foram injetados corpos de prova de PS e PSAI para ensaio de tração e corpos de prova de PSAI para ensaio de impacto.

Um conjunto de cada tipo de corpos de prova foi envelhecido em câmara de intemperismo artificial e outro conjunto foi envelhecido em estação de envelhecimento natural.

Com os corpos de prova para ensaio de tração de PS e de PSAI original e envelhecidos foram realizados testes de tração, DSC e índice de fluidez.

Com os corpos de prova para ensaio de impacto de PSAI original e envelhecidos foram realizados testes de impacto IZOD e índice de fluidez.

Uma avaliação qualitativa da aparência dos corpos de prova foi realizada ao final dos ensaios, assim como uma correlação de dados foi proposta.

\subsubsection{Injeção dos corpos de prova}

Cerca de 230 corpos de prova de PS e PSAI em molde usual para ensaios de tração, tipo I da norma ASTM D638/98, com cerca de $165 \mathrm{~mm}$ de comprimento total (L0), cerca de 57mm de comprimento útil (L), largura total de cerca de $19 \mathrm{~mm}$ (W0), largura útil de 12,6 mm (W) e espessura de 3,3 $\mathrm{mm}(\mathrm{T})$ foram injetados na BASF S.A., assim como os cerca de 160 corpos de prova em molde para ensaio de impacto IZOD de PSAI com posterior entalhe, segundo a norma ASTM D256/97, com profundidade de 12,83 $\mathrm{mm}$, profundidade de entalhe de cerca de 9,60 $\mathrm{mm}$ e espessura de $3,18 \mathrm{~mm}$.

\subsubsection{Envelhecimento artificial}

Foram separados conjuntos de corpos de prova de ensaio de tração para a câmara de intemperismo artificial, expostos em um suporte contendo dois corpos de prova cada 
um, e para a estação de envelhecimento natural do IPT, acondicionados em quadros de madeira confeccionados para este fim, contendo 8 corpos de prova cada um. Foram escolhidos os tempos de zero, 360, 720, 1080, 1440, 1800 e 2160 horas para o ensaio do envelhecimento acelerado em câmara de intemperismo artificial e os corpos de prova foram sendo retirados a medida que o tempo chegava na marca indicada e acondicionados no laboratório do IPT.

Para os corpos de prova de ensaio de impacto foram escolhidos os tempos de zero, $24,90,128,180,270$ e 360 horas, com um conjunto de 12 corpos de prova para cada tempo.

\subsubsection{Normas}

As normas utilizadas foram:

ASTM G26/96 - "Operating Light-Exposure apparatus (xenon-arc type) with and without water for exposure of nonmetallic materials" - Método A. (1996)

ASTM G1555/98 - "Operating xenon arc light apparatus for exposure of nonmetallic materials". (1998)

ASTM G151/97 - "Standard practice for exposing nonmetallic materials in accelerated test devices that use laboratory light sources". (1997)

ASTM D2565/99 - "Standard practice for xenon-arc exposure of plastics intended for outdoor applications". (1999)

ASTM D5071/91 - "Standard practice for operating xenon-arc-type exposure apparatus with water for exposure of photodegradable plastics". (1991)

\subsubsection{Detalhes de ensaio}

Corpos de prova foram acondicionados em placas de $65 \mathrm{~mm}$ x $150 \mathrm{~mm}$ com apenas uma face voltada para a lâmpada. 
A temperatura no corpo-negro foi de $(63 \pm 3)^{\circ} \mathrm{C}$. O tipo de radiação programada no aparelho foi luz natural (do dia). Condições de exposição: ciclos de 102 minutos de luz e 18 minutos de luz com aspersão de água.

\subsubsection{Envelhecimento natural}

Para o envelhecimento natural em exposição às intempéries dos corpos de prova para ensaio de tração foram escolhidos os tempos de zero, 30, 60, 90, 120, 150 e 180 dias para análise do PS e PSAI.

Os corpos de prova foram expostos na Estação de Envelhecimento Natural do IPT, voltados para o norte, em um ângulo de $45^{\circ}$ com a horizontal, no período de 6 de janeiro de 2000 a julho de 2000 . Latitude: $23^{\circ} 34^{\prime}$; Longitude: $46^{\circ} 44^{\prime}$

A cada 30 dias de envelhecimento natural, um conjunto com 8 corpos de prova foi retirado da exposição solar e acondicionados em laboratório no IPT.

Para o envelhecimento dos corpos de prova para ensaio de impacto do PSAI foram escolhidos os tempos de zero, 3, 7, 10, 14, 21 e 31 dias, em conjuntos de 12 corpos de prova para cada tempo.

\subsubsection{Ensaio de tração}

Os corpos de prova foram então avaliados pela variação da resistência à tração no IPT, utilizando-se a norma ASTM D638/98 - "Tensile Properties of Plastics" (1998), com corpos de prova do tipo I e velocidade de separação das garras de $5 \mathrm{~mm} / \mathrm{min}$.

Todo o teste foi registrado e os corpos de prova foram agrupados e "escaneados" para registro.

Para os testes posteriores, os corpos de prova foram cortados em cinco partes, consistindo em 2 conjuntos completos das extremidades dos corpos de prova e 3 conjuntos completos da parte útil para o ensaio de tração. 


\subsubsection{Ensaio de DSC}

Foram retiradas amostras superficiais dos corpos de prova de tração e colocadas de 4 a $6 \mathrm{mg}$ em panela de alumínio, seladas e analisadas em aparelho de DSC segundo a norma ASTM D3418/82 - "Transition Temperatures of Polymers by Thermal Analysis" (1982).

Os dados foram tratados em computador com programação da mesma marca do equipamento, utilizando técnica de alisamento de curva em $1 \%$ e programação automática de determinação de $T_{g}$.

\subsubsection{Ensaio de impacto}

O ensaio de impacto utilizado foi do tipo IZOD com entalhe, de acordo com a norma ASTM D256/97 - "Determining the IZOD Pendulum Impact Resistance of Plastics" (1997), com martelo de $10 \mathrm{kpcm}$.

\subsubsection{Ensaio de índice de fluidez}

Para o ensaio de índice de fluidez, foi utilizada a norma ASTM D1238/2000 "Standard Test Method for Melt Flow Rates of Thermoplastics by Extrusion Plastometer" (2000), em temperatura de $200^{\circ} \mathrm{C}$ e massa de $5 \mathrm{~kg}$, cortando-se o extrudado a cada 10 segundos para o PSAI e durante 45 segundos sem corte para o PS. 


\section{Resultados e Discussão}

\subsection{Resultados}

Neste capítulo estão apresentados os resultados dos ensaios realizados com os corpos de prova degradados em diversos tempos na câmara de intemperismo artificial e na estação de envelhecimento natural do IPT.

Todos os dados apresentados nas tabelas abaixo constam também nas figuras de correlação de dados.

\subsubsection{Ensaio de tração}

O registro de alguns ensaios típicos de tração de PS e de PSAI encontram-se no Anexo A.

As fotos dos corpos de prova após o ensaio de tração de PS e de PSAI encontram-se no Anexo B.

Os resultados do ensaio de tração abaixo são todos médias de 5 valores.

Tabela I: $\quad$ Resultados do ensaio de tração para o PS em envelhecimento natural

\begin{tabular}{|c|c|c|c|}
\hline \multicolumn{4}{|c|}{ PS - Envelhecimento Natural } \\
\hline Tempo (dias) & $\sigma_{\text {rup }}(\mathrm{MPa})$ & $\varepsilon_{\text {tot }}(\%)$ & $\mathrm{E}(\mathrm{MPa})$ \\
\hline 0 & $37,8 \pm 0,3$ & $1,80 \pm 0,05$ & $2380 \pm 30$ \\
\hline 30 & $38 \pm 2$ & $1,9 \pm 0,1$ & $2300 \pm 120$ \\
\hline 60 & $37,7 \pm 0,9$ & $1,93 \pm 0,06$ & $2290 \pm 20$ \\
\hline $90^{*}$ & $33 \pm 3$ & $1,7 \pm 0,2$ & $2250 \pm 60$ \\
\hline $120^{*}$ & $18 \pm 2$ & $0,80 \pm 0,09$ & $2500 \pm 300$ \\
\hline $150^{*}$ & $19 \pm 5$ & $0,9 \pm 0,3$ & $2300 \pm 90$ \\
\hline $180^{*}$ & $15 \pm 3$ & $0,8 \pm 0,2$ & $1700 \pm 90$ \\
\hline
\end{tabular}

* conjuntos de dados assinalados tiveram rompimento em tração fora da área útil dos corpos de prova 
Tabela II: Resultados do ensaio de tração para o PS em envelhecimento artificial

\begin{tabular}{|c|c|c|c|}
\hline \multicolumn{5}{|c|}{ PS - Envelhecimento Artificial } \\
\hline Tempo (horas) & $\sigma_{\text {rup }}(\mathrm{MPa})$ & $\varepsilon_{\text {tot }}(\%)$ & E (MPa) \\
\hline 0 & $37,8 \pm 0,3$ & $1,80 \pm 0,05$ & $2380 \pm 30$ \\
\hline 360 & $35 \pm 3$ & $1,8 \pm 0,2$ & $2260 \pm 80$ \\
\hline $720^{*}$ & $19 \pm 4$ & $1,0 \pm 0,3$ & $2190 \pm 70$ \\
\hline $1080^{*}$ & $15 \pm 3$ & $0,7 \pm 0,1$ & $2340 \pm 40$ \\
\hline 1440 & $10 \pm 2$ & $0,5 \pm 0,1$ & $2200 \pm 400$ \\
\hline 1800 & $9 \pm 1$ & $0,39 \pm 0,05$ & $2280 \pm 90$ \\
\hline 2160 & $8,0 \pm 0,6$ & $0,35 \pm 0,03$ & $2320 \pm 70$ \\
\hline
\end{tabular}

Tabela III: Resultados do ensaio de tração para o PSAI em envelhecimento natural

\begin{tabular}{|c|c|c|c|c|}
\hline \multicolumn{5}{|c|}{ PSAI - Envelhecimento Natural } \\
\hline Tempo (dias) & $\sigma_{\text {esc }}(\mathrm{MPa})$ & $\sigma_{\text {rup }}(\mathrm{MPa})$ & $\varepsilon_{\text {tot }}(\%)$ & $\mathrm{E}(\mathrm{MPa})$ \\
\hline 0 & $19,3 \pm 0,2$ & $19,3 \pm 0,2$ & $40 \pm 7$ & $1600 \pm 100$ \\
\hline 30 & $18,9 \pm 0,3$ & $16 \pm 1$ & $1,9 \pm 0,2$ & $1500 \pm 50$ \\
\hline 60 & $17 \pm 1$ & $17 \pm 1$ & $1,17 \pm 0,08$ & $1600 \pm 70$ \\
\hline 90 & $16 \pm 1$ & $15 \pm 2$ & $0,9 \pm 0,2$ & $2000 \pm 800$ \\
\hline 120 & $16 \pm 1$ & $15 \pm 2$ & $0,93 \pm 0,05$ & $1740 \pm 10$ \\
\hline 150 & $16 \pm 2$ & $16 \pm 2$ & $0,9 \pm 0,1$ & $1730 \pm 40$ \\
\hline 180 & $15 \pm 1$ & $15 \pm 1$ & $0,92 \pm 0,09$ & $1710 \pm 90$ \\
\hline
\end{tabular}

\footnotetext{
* conjuntos de dados assinalados tiveram rompimento em tração fora da área útil dos corpos de prova
} 
Tabela IV: Resultados do ensaio de tração para o PSAI em envelhecimento artificial

\begin{tabular}{|c|c|c|c|c|}
\hline \multicolumn{5}{|c|}{ PSAI - Envelhecimento Artificial } \\
\hline Tempo (horas) & $\sigma_{\text {esc }}(\mathrm{MPa})$ & $\sigma_{\text {rup }}(\mathrm{MPa})$ & $\varepsilon_{\text {tot }}(\%)$ & $\mathrm{E}(\mathrm{MPa})$ \\
\hline 0 & $19,3 \pm 0,2$ & $19,3 \pm 0,2$ & $40 \pm 7$ & $1600 \pm 100$ \\
\hline 360 & $18,1 \pm 0,9$ & $17 \pm 1$ & $1,2 \pm 0,1$ & $1640 \pm 60$ \\
\hline 720 & $18 \pm 1$ & $17 \pm 1$ & $1,2 \pm 0,2$ & $1670 \pm 80$ \\
\hline 1080 & $17 \pm 1$ & $17 \pm 1$ & $1,0 \pm 0,1$ & $1620 \pm 60$ \\
\hline 1440 & $16,2 \pm 0,5$ & $16,0 \pm 0,9$ & $0,98 \pm 0,02$ & $1760 \pm 40$ \\
\hline 1800 & $15 \pm 2$ & $15 \pm 2$ & $1,0 \pm 0,2$ & $1700 \pm 200$ \\
\hline 2160 & $15,8 \pm 0,6$ & $15,2 \pm 0,7$ & $1,0 \pm 0,1$ & $1740 \pm 80$ \\
\hline
\end{tabular}

\subsubsection{Ensaio de DSC}

A seguir estão os termogramas do ensaio de DSC.

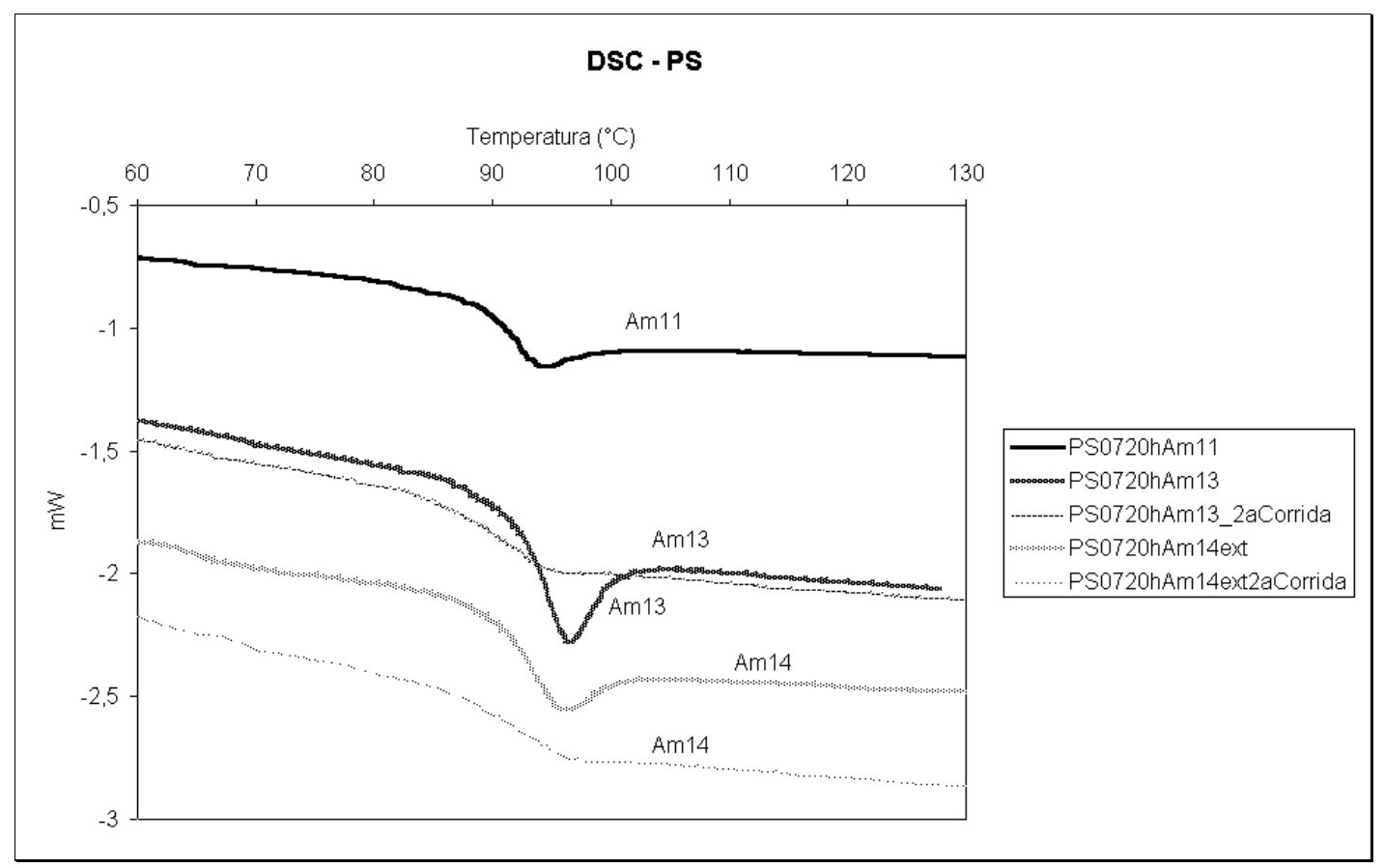

Figura 3: Curvas do ensaio de DSC do PS em envelhecimento acelerado em 720h com várias amostras 


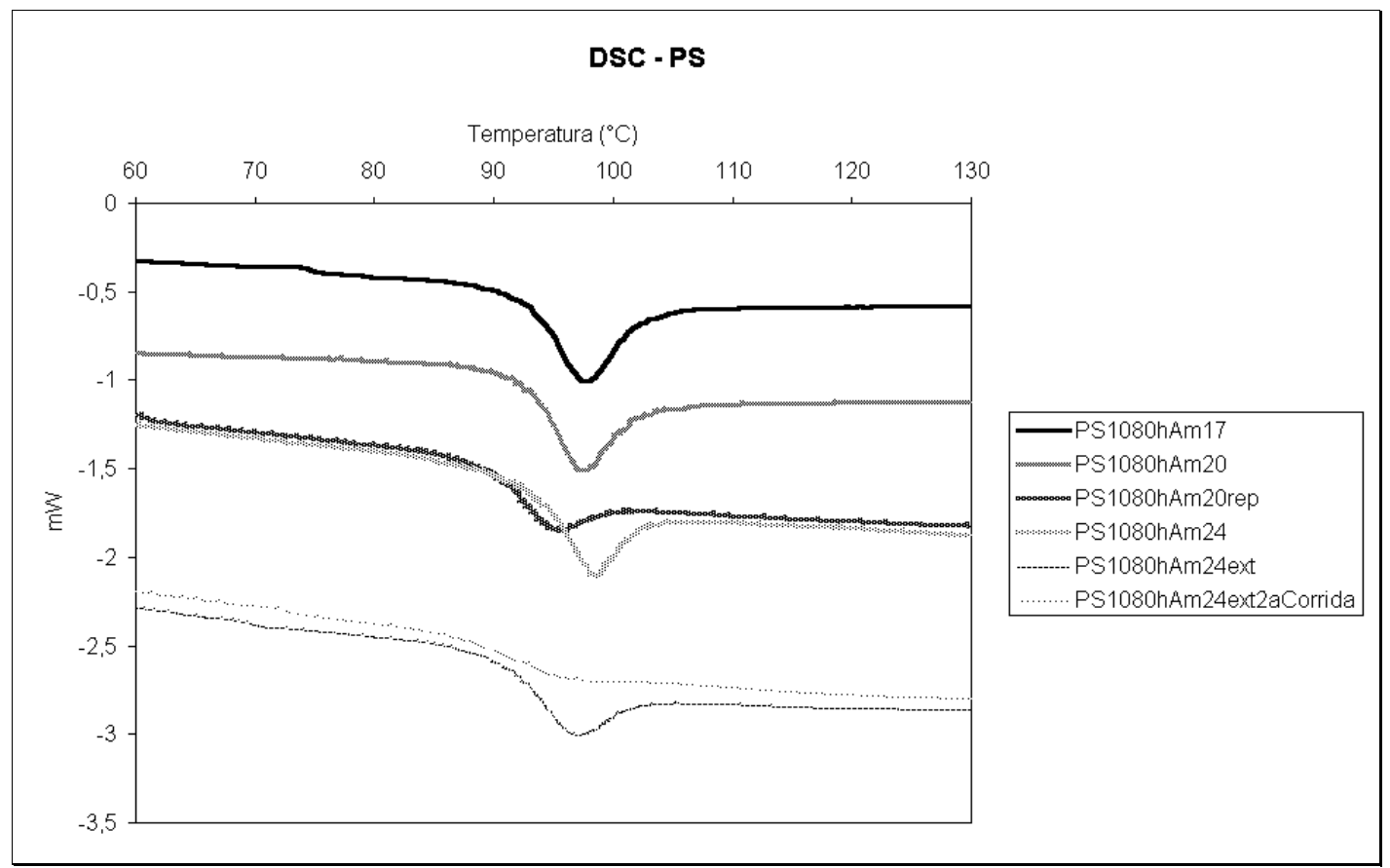

Figura 4: Curvas do ensaio de DSC do PS em envelhecimento acelerado em 1080h com várias amostras

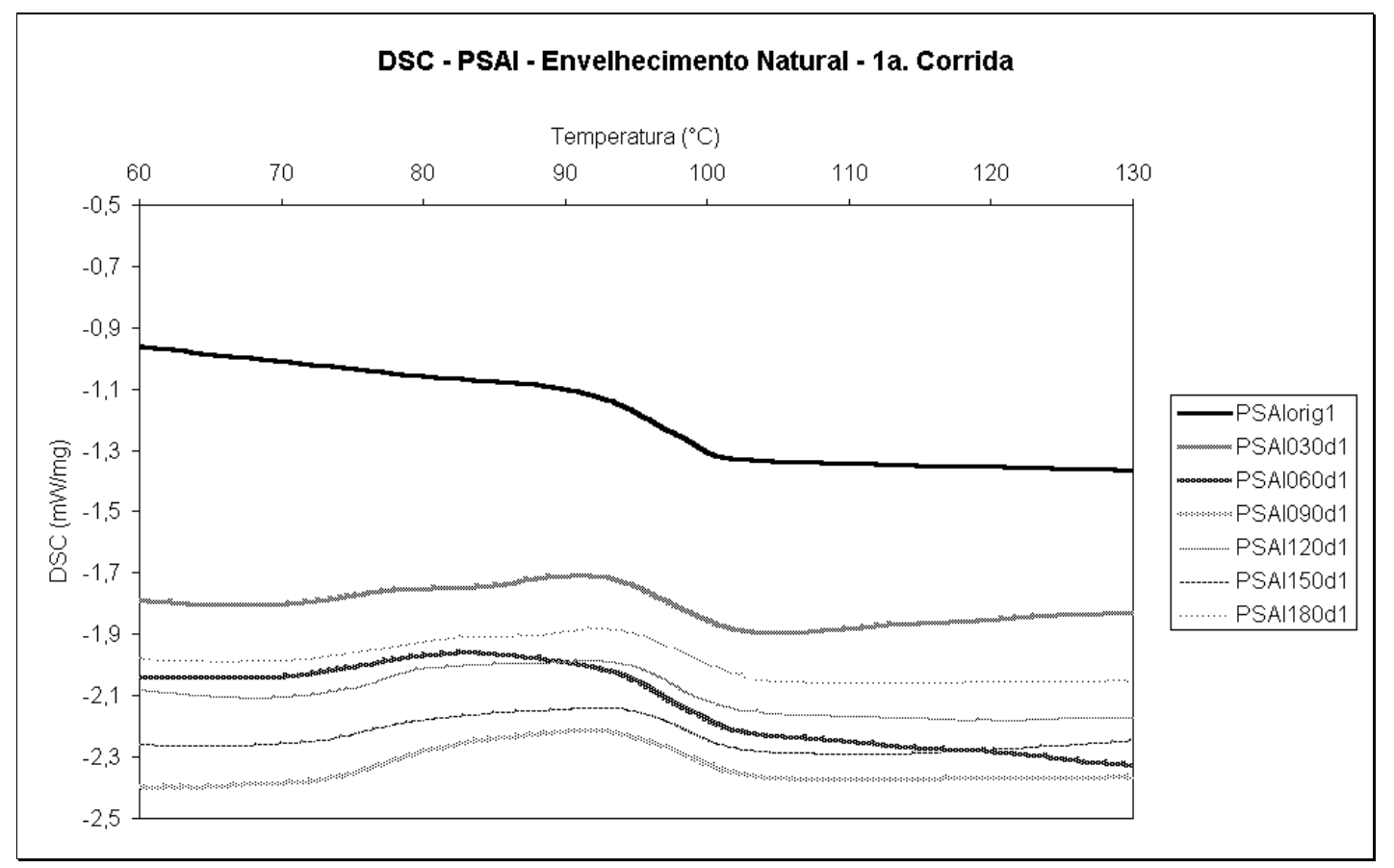

Figura 5: Curvas do ensaio de DSC do PS em envelhecimento natural, 1 a corrida 


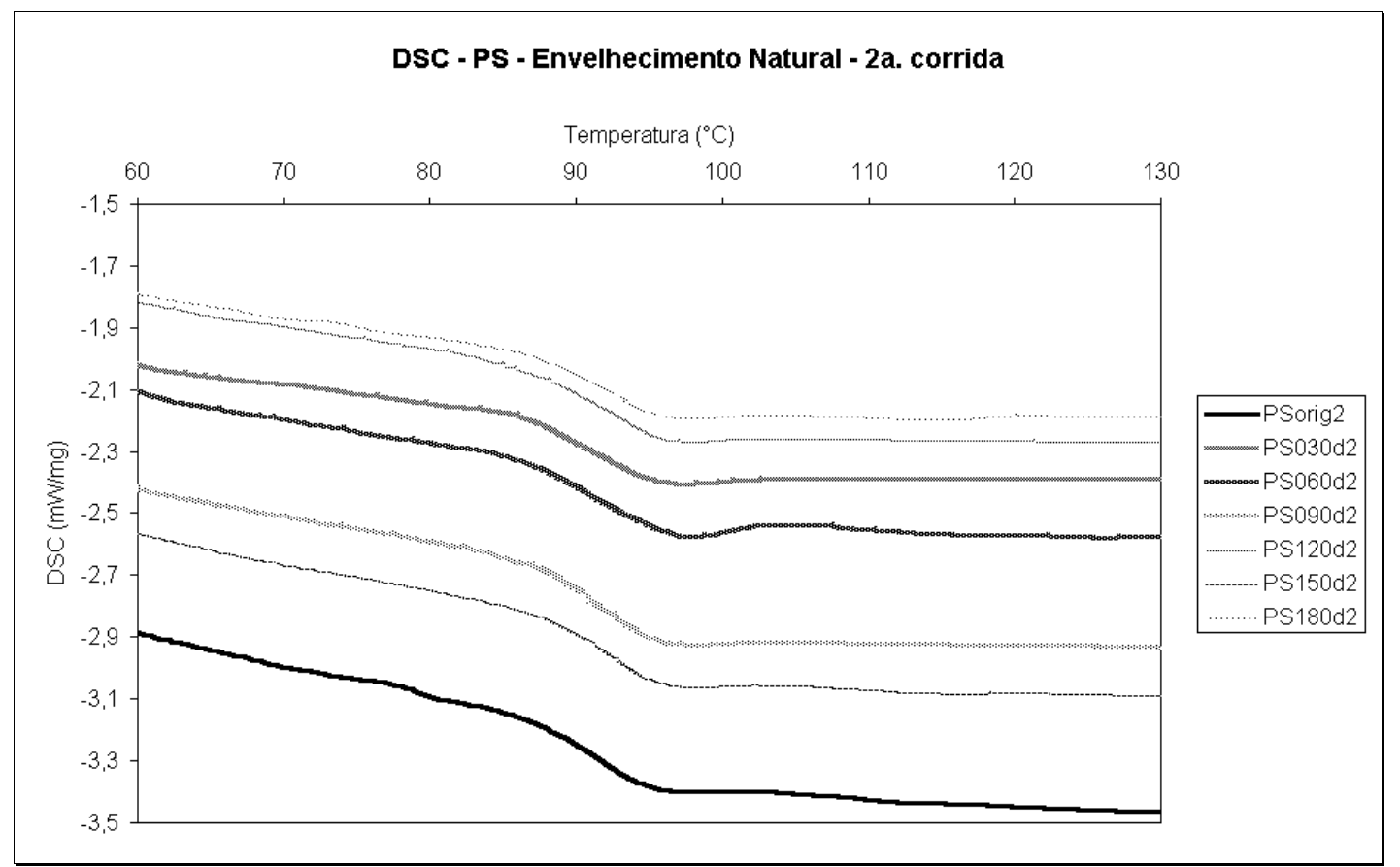

Figura 6: Curvas do ensaio de DSC do PS em envelhecimento natural, $2^{\mathrm{a}}$ corrida

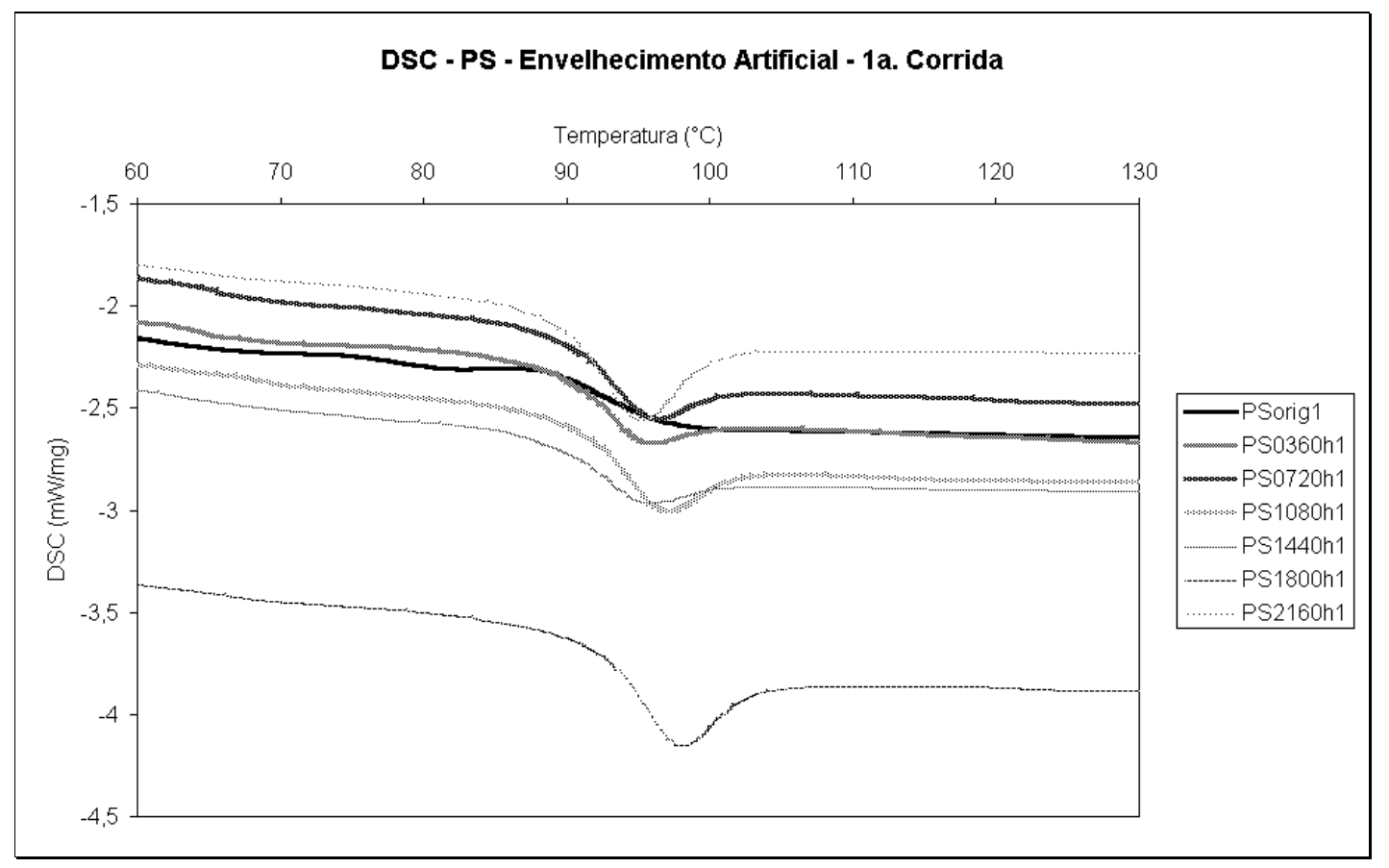

Figura 7: Curvas do ensaio de DSC do PS em envelhecimento acelerado, 1 a corrida 


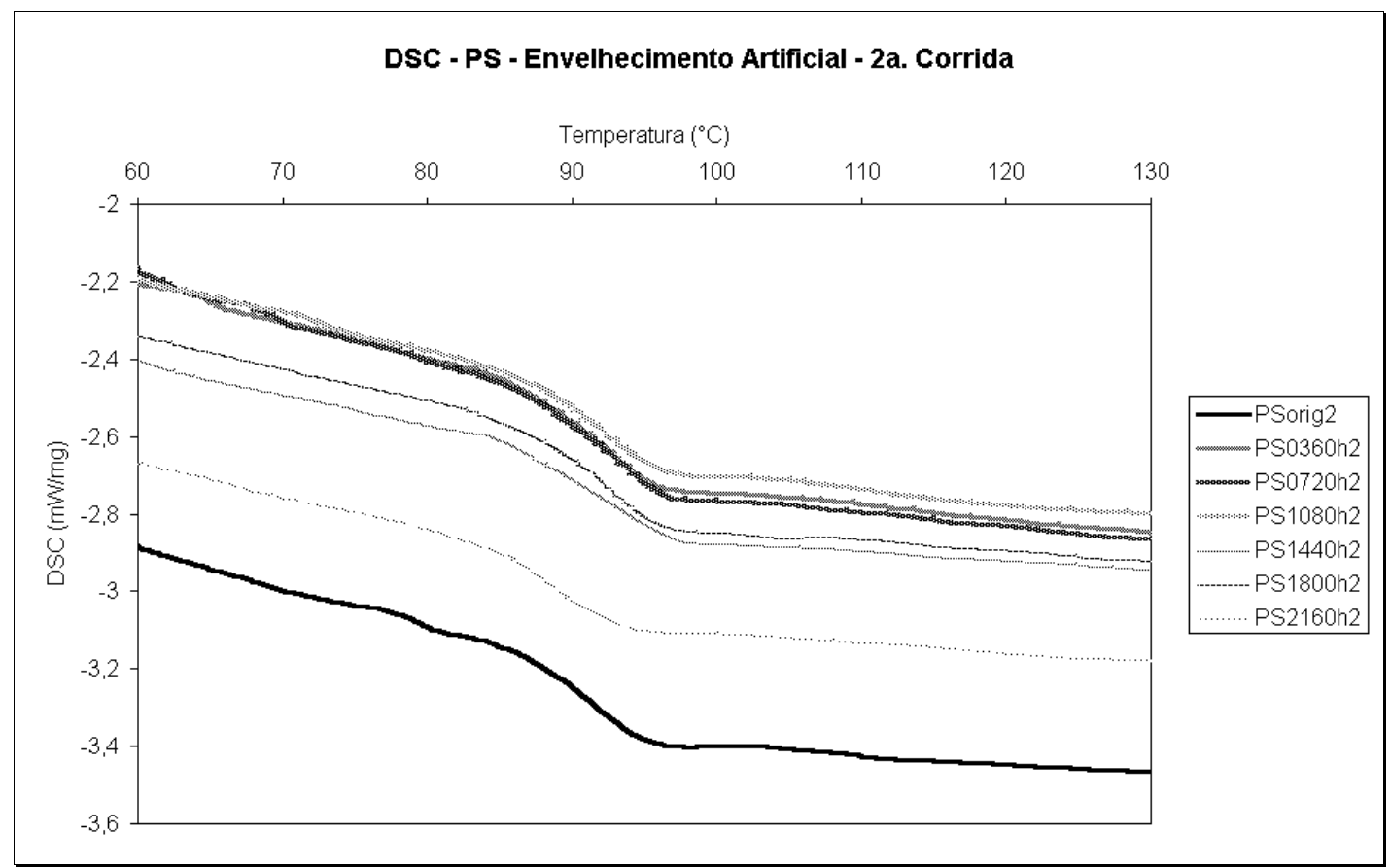

Figura 8: Curvas do ensaio de DSC do PS em envelhecimento acelerado, $2^{\text {a }}$ corrida

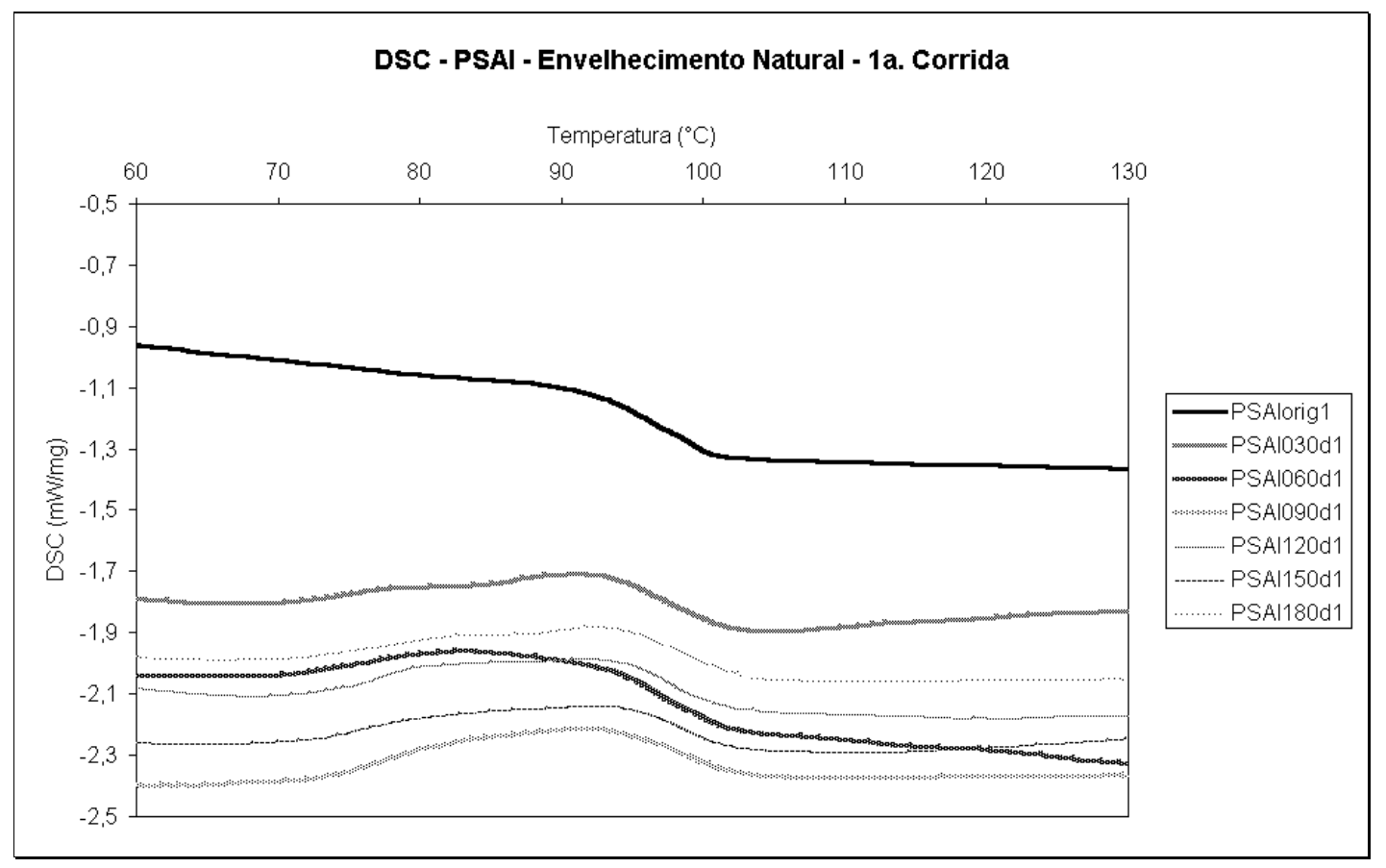

Figura 9: Curvas do ensaio de DSC do PSAI em envelhecimento natural, $1^{\text {a }}$ corrida 


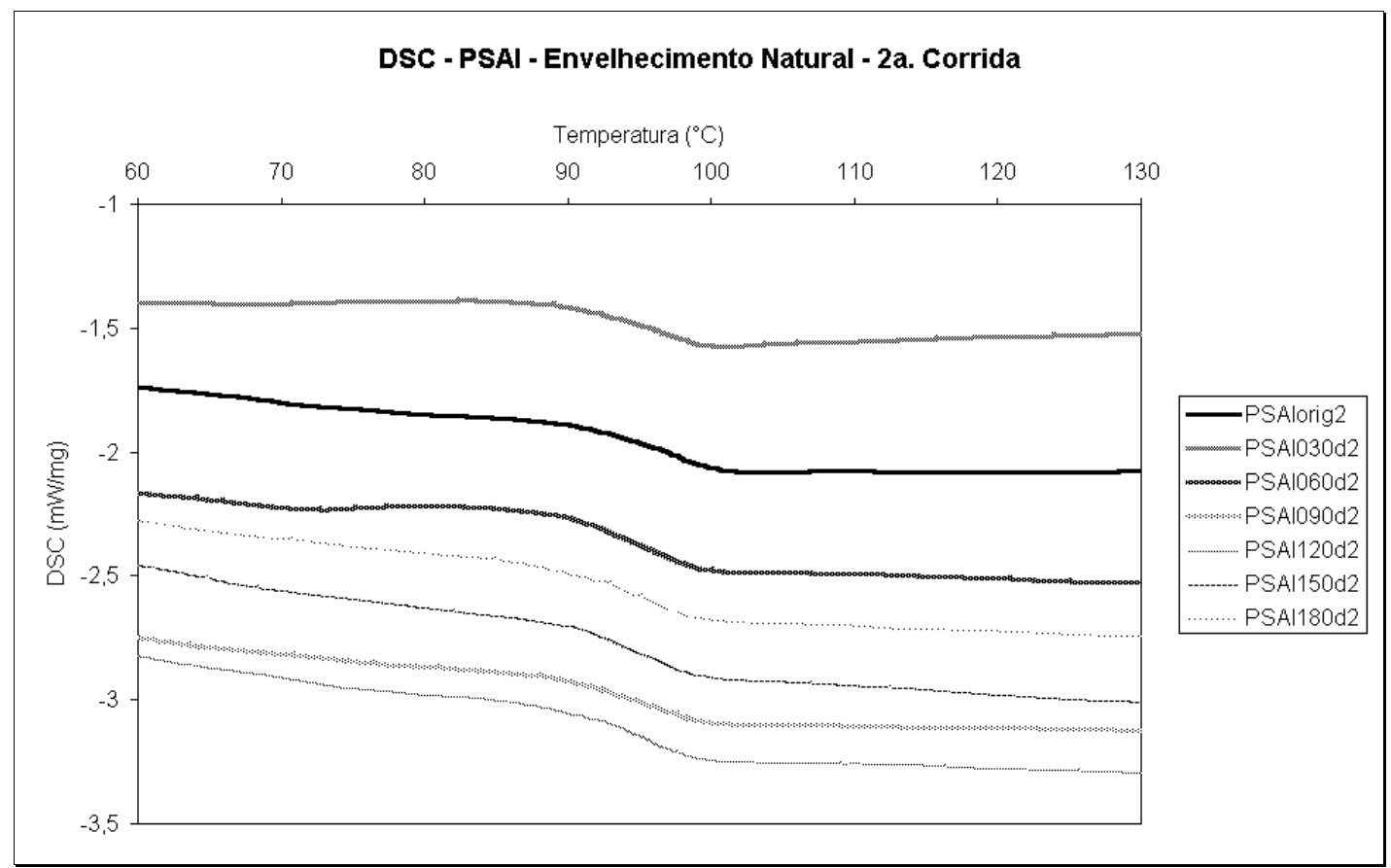

Figura 10: Curvas do ensaio de DSC do PSAI em envelhecimento natural, $2^{\mathrm{a}}$ corrida

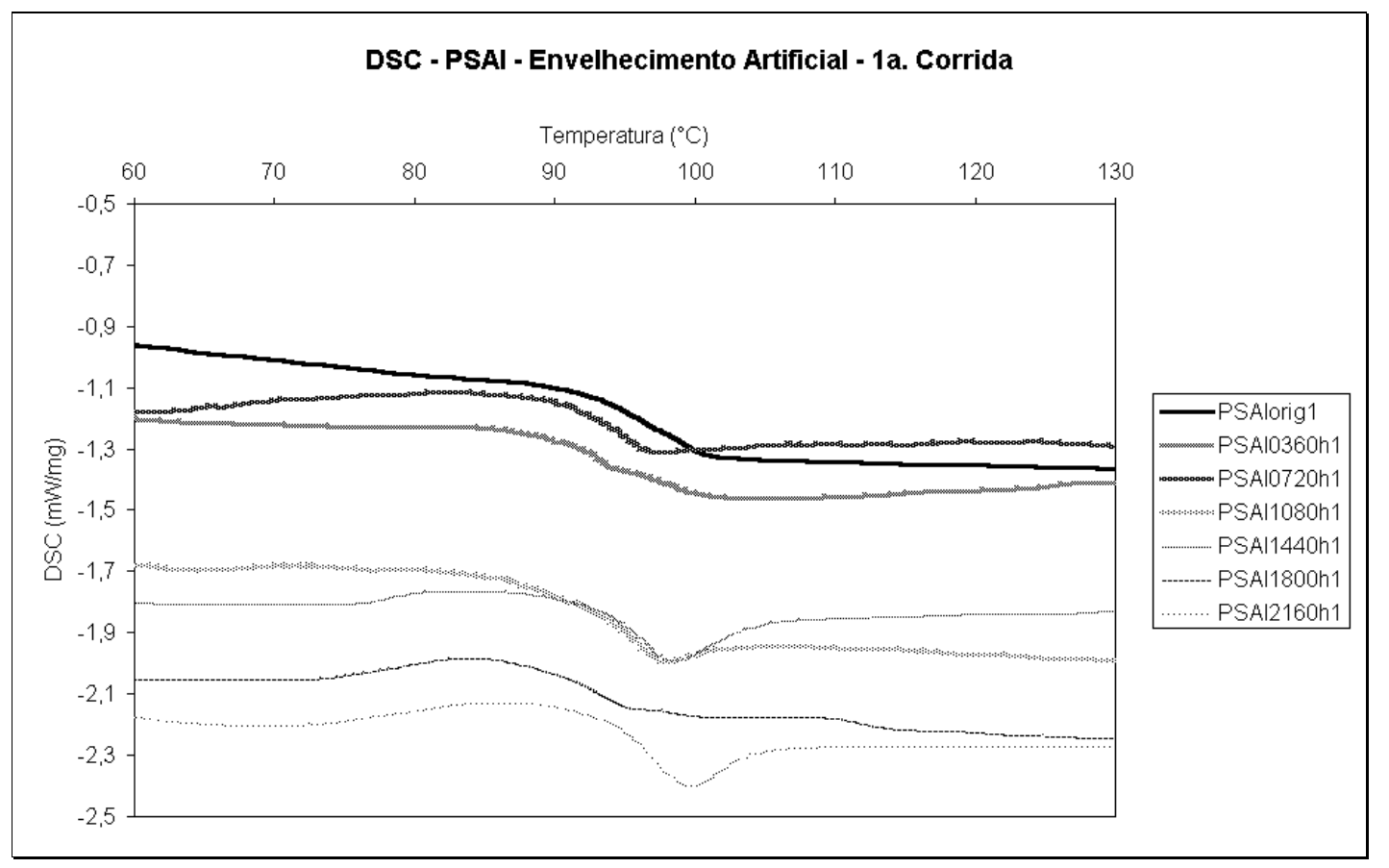

Figura 11: Curvas do ensaio de DSC do PSAI em envelhecimento acelerado, $1^{\text {a }}$ corrida 


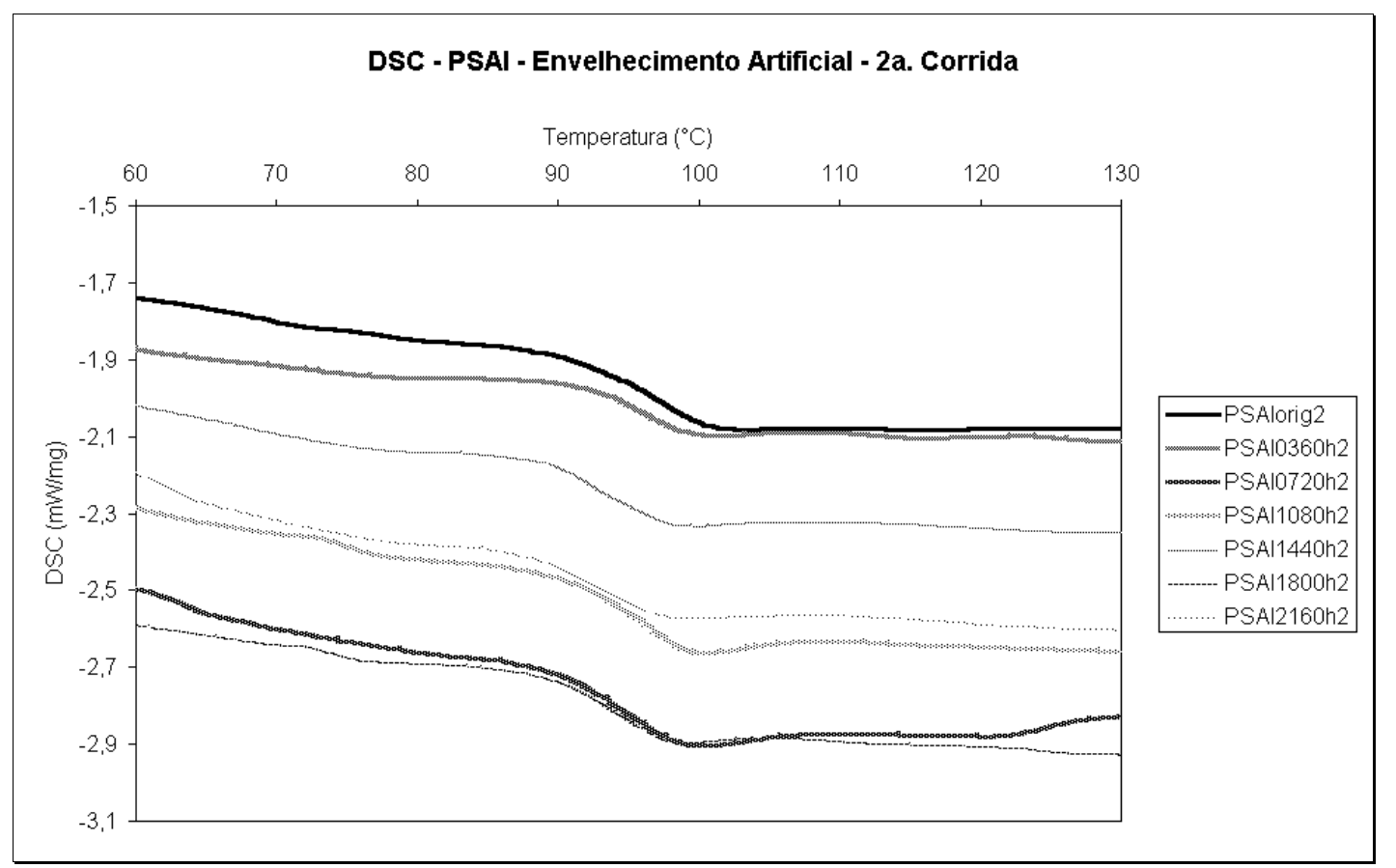

Figura 12: Curvas do ensaio de DSC do PSAI em envelhecimento acelerado, $2^{\text {a }}$ corrida

Os dados apresentados a seguir têm um erro de procedimento estimado em $2 \%$ e foram utilizados resultados das segundas corridas no DSC para a correlação.

Tabela V: $\quad$ Resultados de $T_{g}$ do DSC para o PS

\begin{tabular}{|c|c|c|c|c|c|}
\hline \multicolumn{6}{|c|}{ PS } \\
\hline \multicolumn{2}{|c|}{ Envelhecimento Natural } & \multicolumn{3}{c|}{ Envelhecimento Artificial } \\
\hline Tempo (dias) & $\begin{array}{c}T_{g}\left({ }^{\circ} \mathrm{C}\right) \\
1^{\mathrm{a}} \text { corrida }\end{array}$ & $\begin{array}{c}T_{g}\left({ }^{\circ} \mathrm{C}\right) \\
2^{\mathrm{a}} \text { corrida }\end{array}$ & Tempo (horas) & $\begin{array}{c}T_{g}\left({ }^{\circ} \mathrm{C}\right) \\
1^{\mathrm{a}} \text { corrida }\end{array}$ & $\begin{array}{c}T_{g}\left({ }^{\circ} \mathrm{C}\right) \\
2^{\mathrm{a}} \text { corrida }\end{array}$ \\
\hline 0 & 93 & 92 & 0 & 93 & 92 \\
\hline 30 & 94 & 91 & 360 & 92 & 93 \\
\hline 60 & 94 & 92 & 720 & 92 & 94 \\
\hline 90 & 94 & 93 & 1080 & 93 & 94 \\
\hline 120 & 94 & 94 & 1440 & 92 & 93 \\
\hline 150 & 94 & 93 & 1800 & 94 & 91 \\
\hline
\end{tabular}


Tabela VI: $\quad$ Resultados de $T_{g}$ do DSC para o PSAI

\begin{tabular}{|c|c|c|c|c|c|}
\hline \multicolumn{6}{|c|}{ PS } \\
\hline \multicolumn{2}{|c|}{ Envelhecimento Natural } & \multicolumn{3}{c|}{ Envelhecimento Artificial } \\
\hline Tempo (dias) & $\begin{array}{c}T_{g}\left({ }^{\circ} \mathrm{C}\right) \\
1^{\mathrm{a}} \text { corrida }\end{array}$ & $\begin{array}{c}T_{g}\left({ }^{\circ} \mathrm{C}\right) \\
2^{\mathrm{a}} \text { corrida }\end{array}$ & Tempo (horas) & $\begin{array}{c}T_{g}\left({ }^{\circ} \mathrm{C}\right) \\
1^{\mathrm{a}} \text { corrida }\end{array}$ & $\begin{array}{c}T_{g}\left({ }^{\circ} \mathrm{C}\right) \\
2^{\mathrm{a}} \text { corrida }\end{array}$ \\
\hline 0 & 96 & 97 & 0 & 96 & 97 \\
\hline 30 & 98 & 96 & 360 & 94 & 96 \\
\hline 60 & 97 & 95 & 720 & 94 & 96 \\
\hline 90 & 99 & 96 & 1080 & 94 & 96 \\
\hline 120 & 98 & 96 & 1440 & 94 & 95 \\
\hline 150 & 98 & 96 & 1800 & 93 & 93 \\
\hline
\end{tabular}

\subsubsection{Ensaio de impacto IZOD}

Os resultados do ensaio de impacto são médias de 10 valores.

Tabela VII: Resultados de impacto IZOD do PSAI, convertidos para o sistema internacional

\begin{tabular}{|c|c|c|c|}
\hline \multicolumn{2}{|c|}{ PSAI } \\
\hline \multicolumn{2}{|c|}{ Envelhecimento Natural } & Tempo (horas) & $I_{s}\left(\mathrm{~kJ} / \mathrm{m}^{2}\right)$ \\
\hline Tempo (dias) & $I_{S}\left(\mathrm{~kJ} / \mathrm{m}^{2}\right)$ & 0 & $12 \pm 1$ \\
\hline 0 & $12 \pm 1$ & 24 & $11,2 \pm 0,9$ \\
\hline 3 & $10,4 \pm 0,8$ & 90 & $9 \pm 0,3$ \\
\hline 7 & $10,5 \pm 0,3$ & 128 & $9,1 \pm 1$ \\
\hline 10 & $9 \pm 1$ & 180 & $8,6 \pm 0,6$ \\
\hline 14 & $9,2 \pm 0,9$ & 270 & $7,3 \pm 0,6$ \\
\hline 21 & $8,5 \pm 0,8$ & 360 & $7,8 \pm 0,3$ \\
\hline 31 & $8,1 \pm 0,5$ & & \\
\hline
\end{tabular}




\subsubsection{Ensaio de índice de fluidez}

Os resultados do ensaio de índice de fluidez são médias de 6 valores para os PSAI e dados unitários com erro de método para os PS.

Tabela VIII: Resultados de índice de fluidez do PS

\begin{tabular}{|c|c|c|c|}
\hline \multicolumn{4}{|c|}{ PS } \\
\hline \multicolumn{2}{|c|}{ Envelhecimento Natural } & Envelhecimento Artificial \\
\hline Tempo (dias) & MFR (g/10min) & Tempo (horas) & MFR (g/10min) \\
\hline 0 & $21,8 \pm 0,2$ & 0 & $21,8 \pm 0,2$ \\
\hline 30 & $24,7 \pm 0,2$ & 360 & $27,4 \pm 0,2$ \\
\hline 60 & $26,9 \pm 0,2$ & 720 & $41,7 \pm 0,3$ \\
\hline 90 & $35,5 \pm 0,3$ & 1080 & $51,7 \pm 0,4$ \\
\hline 120 & $37,5 \pm 0,3$ & 1440 & $63,7 \pm 0,5$ \\
\hline 150 & $41,3 \pm 0,3$ & 1800 & $78,6 \pm 0,6$ \\
\hline 180 & $40,9 \pm 0,3$ & 2160 & $99,4 \pm 0,8$ \\
\hline
\end{tabular}

Tabela IX: $\quad$ Resultados de índice de fluidez do PSAI

\begin{tabular}{|c|c|c|c|}
\hline \multicolumn{5}{|c|}{ PSAI } \\
\hline \multicolumn{2}{|c|}{ Envelhecimento Natural } & \multicolumn{2}{|c|}{ Envelhecimento Artificial } \\
\hline Tempo (dias) & MFR (g/10min) & Tempo (horas) & MFR (g/10min) \\
\hline 0 & $4,23 \pm 0,09$ & 0 & $4,23 \pm 0,09$ \\
\hline 30 & $4,35 \pm 0,09$ & 360 & $5,2 \pm 0,2$ \\
\hline 60 & $5,5 \pm 0,2$ & 720 & $5,3 \pm 0,1$ \\
\hline 90 & $5,9 \pm 0,2$ & 1080 & $5,4 \pm 0,5$ \\
\hline 120 & $5,5 \pm 0,2$ & 1440 & $7,1 \pm 0,3$ \\
\hline 150 & $6 \pm 0,1$ & 1800 & $5,8 \pm 0,2$ \\
\hline 180 & $6,7 \pm 0,2$ & 2160 & $6,3 \pm 0,3$ \\
\hline
\end{tabular}


Tabela X: Resultados de índice de fluidez para corpos de prova de impacto do PSAI

\begin{tabular}{|c|c|c|c|}
\hline \multicolumn{4}{|c|}{ PSAI - corpos de prova de impacto } \\
\hline \multicolumn{3}{|c|}{ Envelhecimento Natural } & \multicolumn{2}{|c|}{ Envelhecimento Artificial } \\
\hline Tempo (dias) & MFR (g/10min) & Tempo (horas) & MFR (g/10min) \\
\hline 0 & $4,8 \pm 0,2$ & 0 & $4,8 \pm 0,2$ \\
\hline 3 & $4,88 \pm 0,05$ & 24 & $5 \pm 0,1$ \\
\hline 7 & $5,12 \pm 0,09$ & 90 & $5,1 \pm 0,1$ \\
\hline 10 & $4,9 \pm 0,2$ & 128 & $5,5 \pm 0,1$ \\
\hline 14 & $4,9 \pm 0,1$ & 180 & $5,2 \pm 0,3$ \\
\hline 21 & $4,8 \pm 0,1$ & 270 & $5,10 \pm 0,08$ \\
\hline 31 & $5,3 \pm 0,3$ & 360 & $3,22 \pm 0,05$ \\
\hline
\end{tabular}

\subsubsection{Correlação}

Dados de correlação entre o envelhecimento artificial de PS com um fator de aceleração de 4 em relação ao envelhecimento natural e fator de 2 para o PSAI.

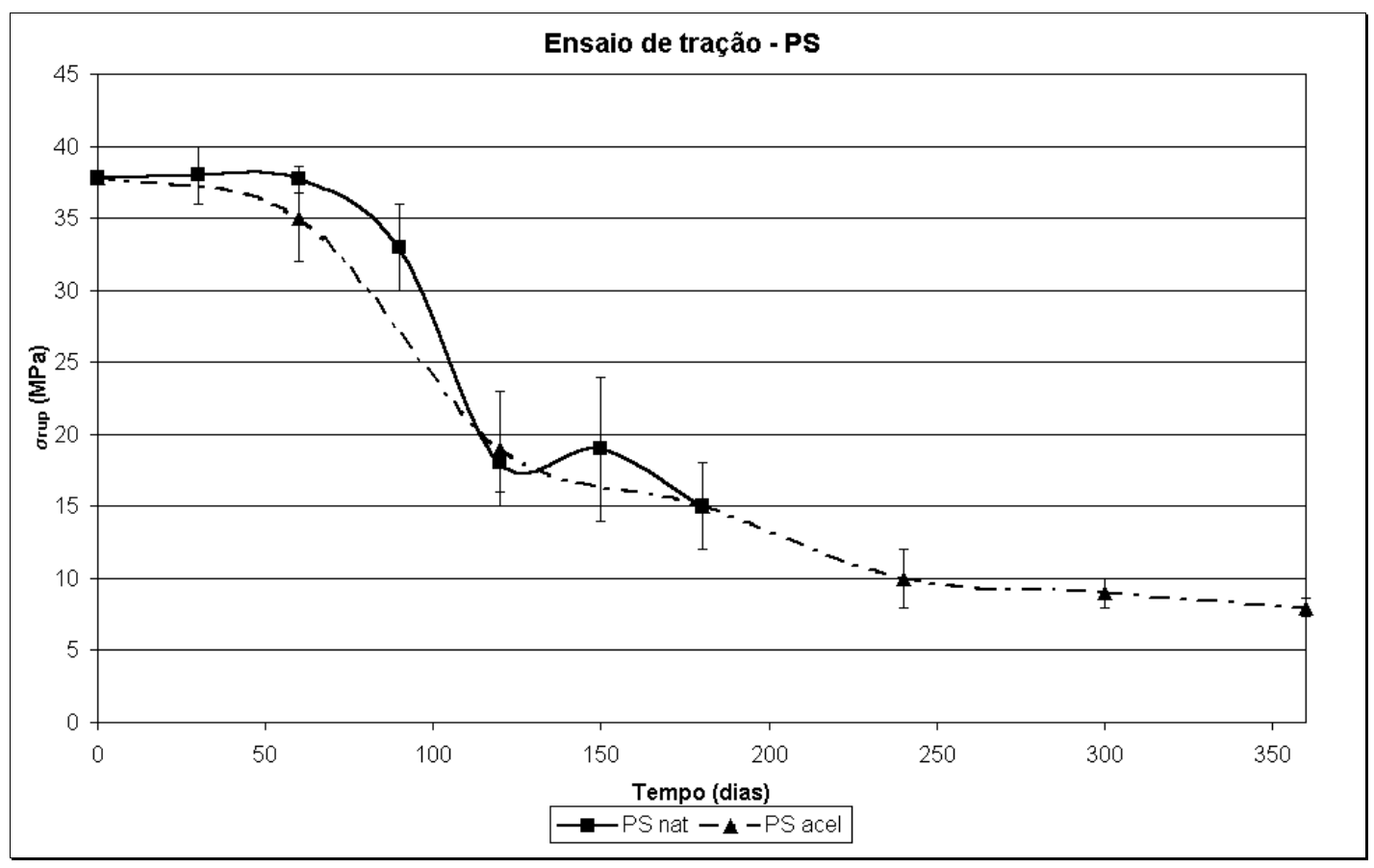

Figura 13: Tensão na ruptura em tração de PS de acordo com o envelhecimento. Tempos do envelhecimento artificial estão multiplicados por um fator de aceleração de 4. 


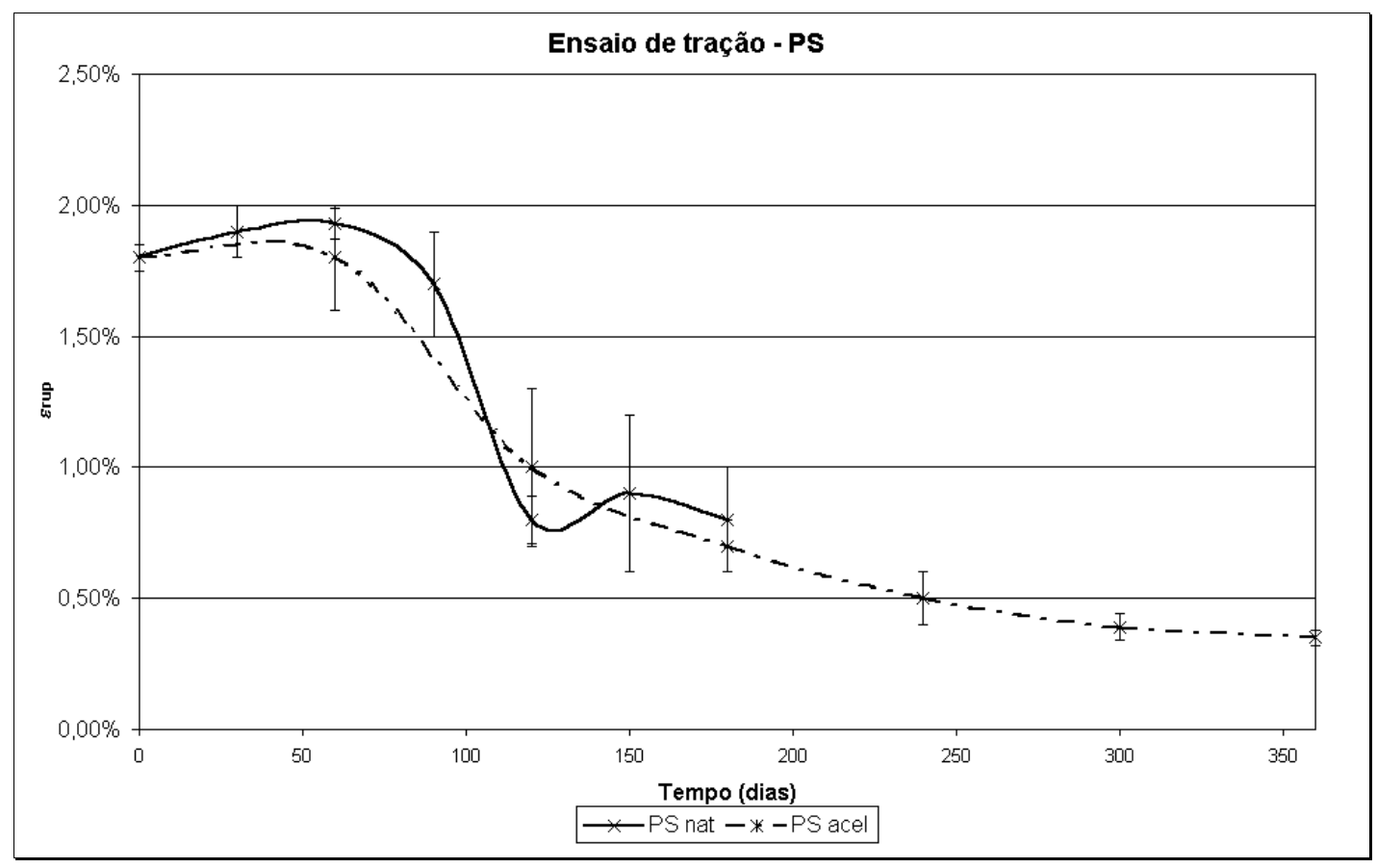

Figura 14: Elongação na ruptura em tração de PS de acordo com o envelhecimento. Tempos do envelhecimento artificial estão multiplicados por um fator de aceleração de 4.

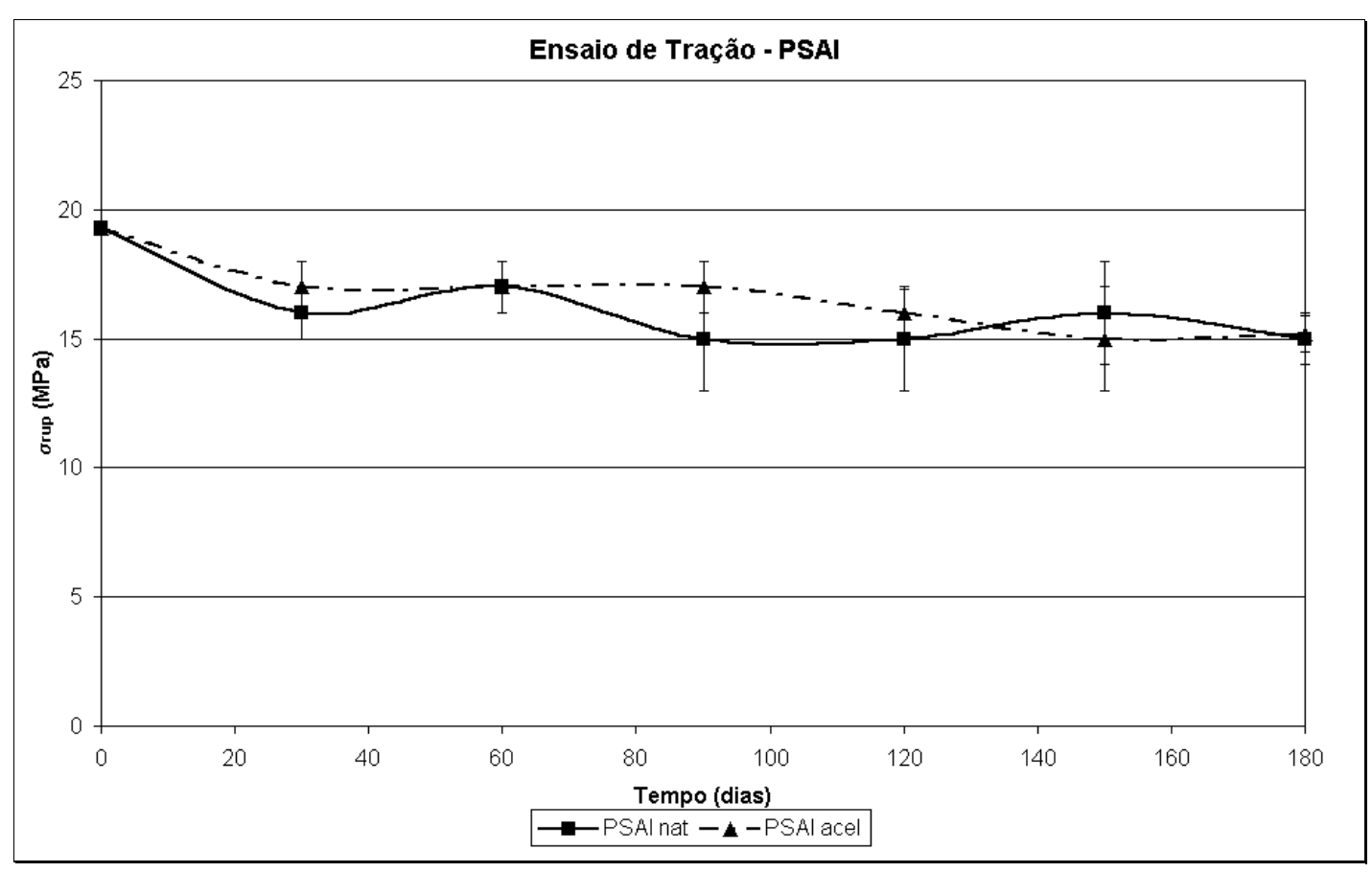

Figura 15: Tensão na ruptura em tração de PSAI de acordo com o envelhecimento. Tempos do envelhecimento artificial estão multiplicados por um fator de aceleração de 2 . 


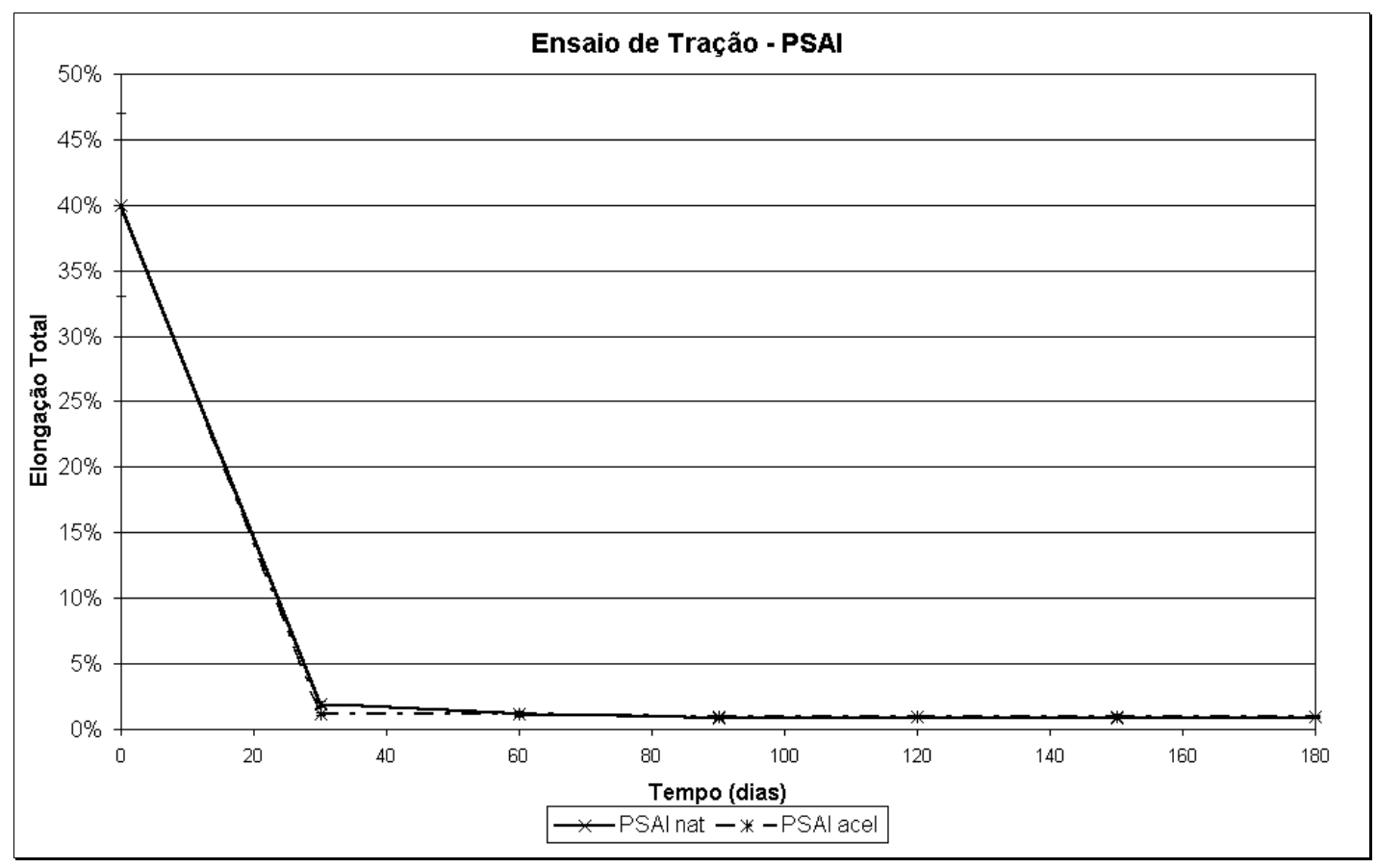

Figura 16: Elongação na ruptura em tração de PSAI de acordo com o envelhecimento. Tempos do envelhecimento artificial estão multiplicados por um fator de aceleração de 2 .

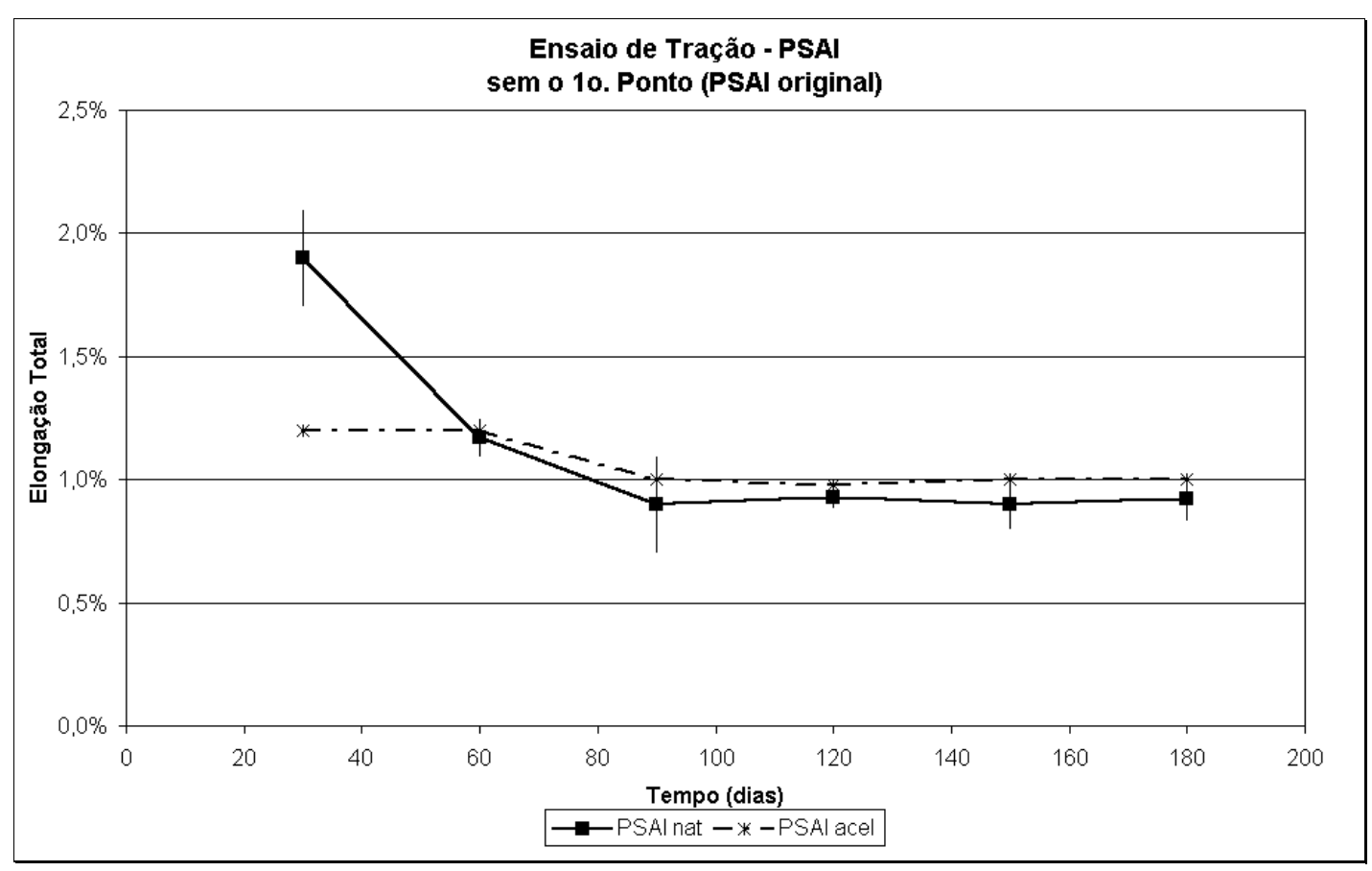

Figura 17: Elongação na ruptura em tração de PSAI de acordo com o envelhecimento, sem o ponto inicial. Tempos do envelhecimento artificial estão multiplicados por um fator de aceleração de 2. 


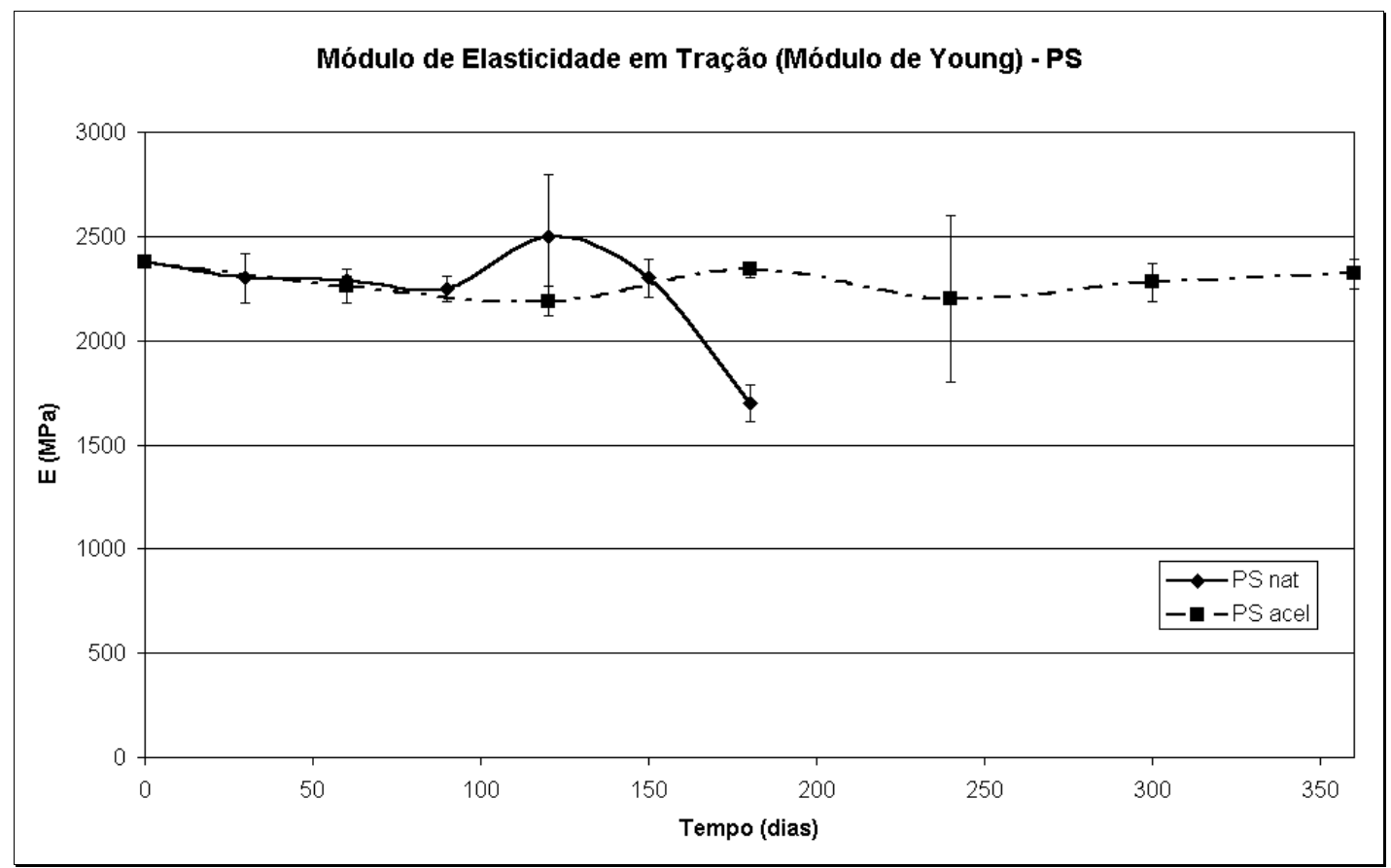

Figura 18: Módulo de elasticidade em tração (Módulo de Young) de PS de acordo com o envelhecimento. Tempos do envelhecimento artificial estão multiplicados por um fator de aceleração de 4.

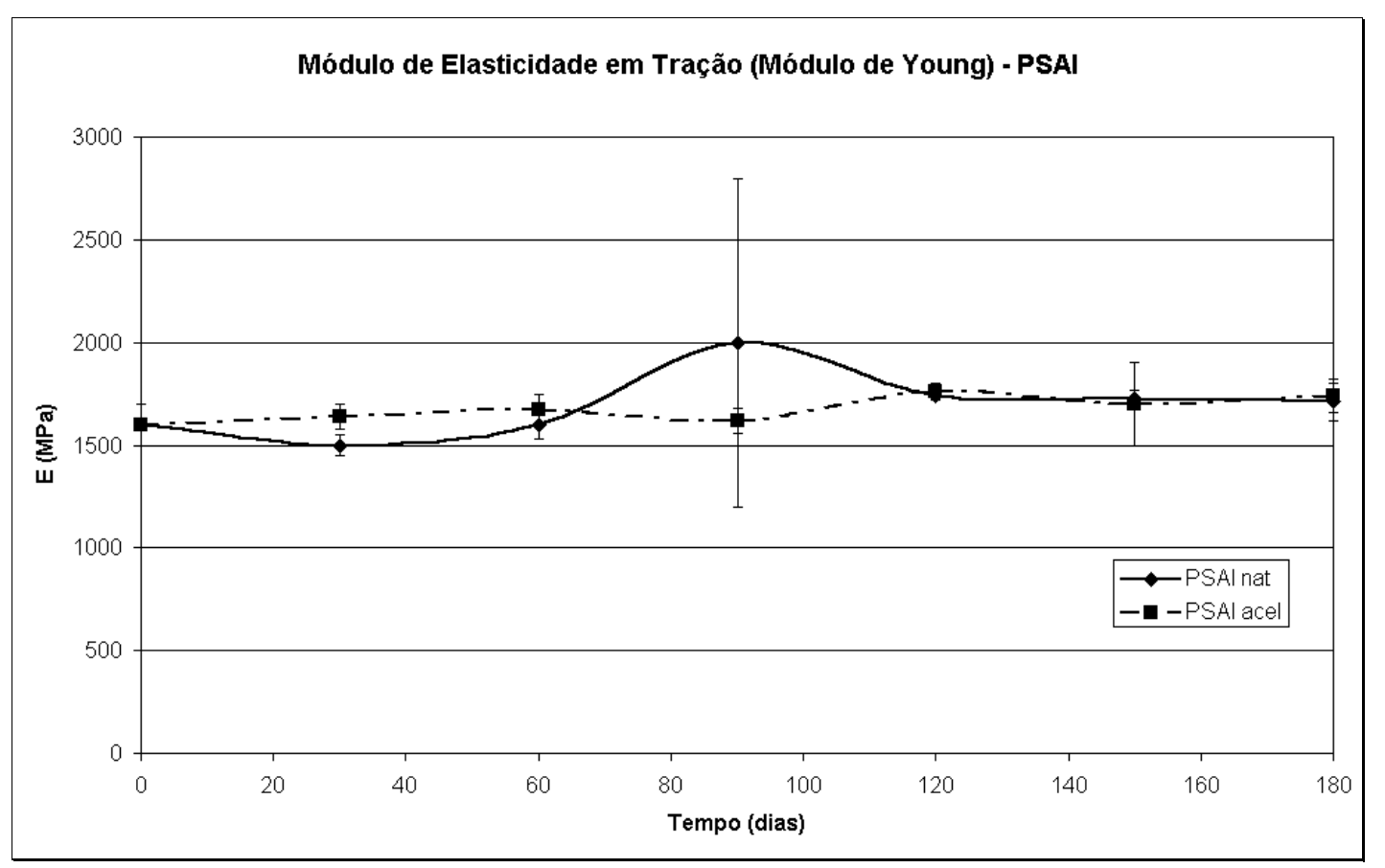

Figura 19: Módulo de elasticidade em tração (Módulo de Young) de PSAI de acordo com o envelhecimento. Tempos do envelhecimento artificial estão multiplicados por um fator de aceleração de 2 . 


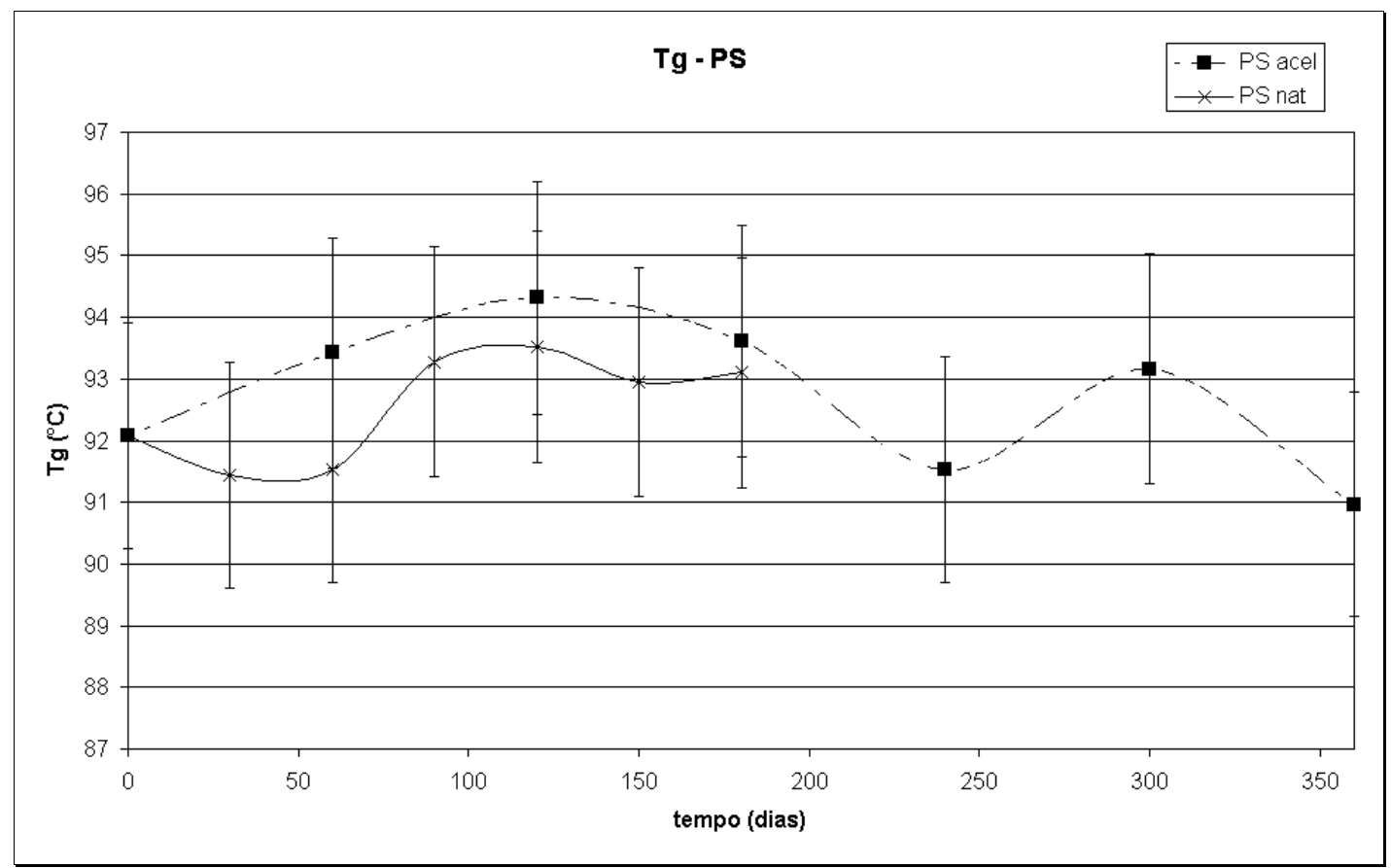

Figura 20: Temperaturas de transição vítrea de PS de acordo com o envelhecimento. Tempos do envelhecimento artificial estão multiplicados por um fator de aceleração de 4.

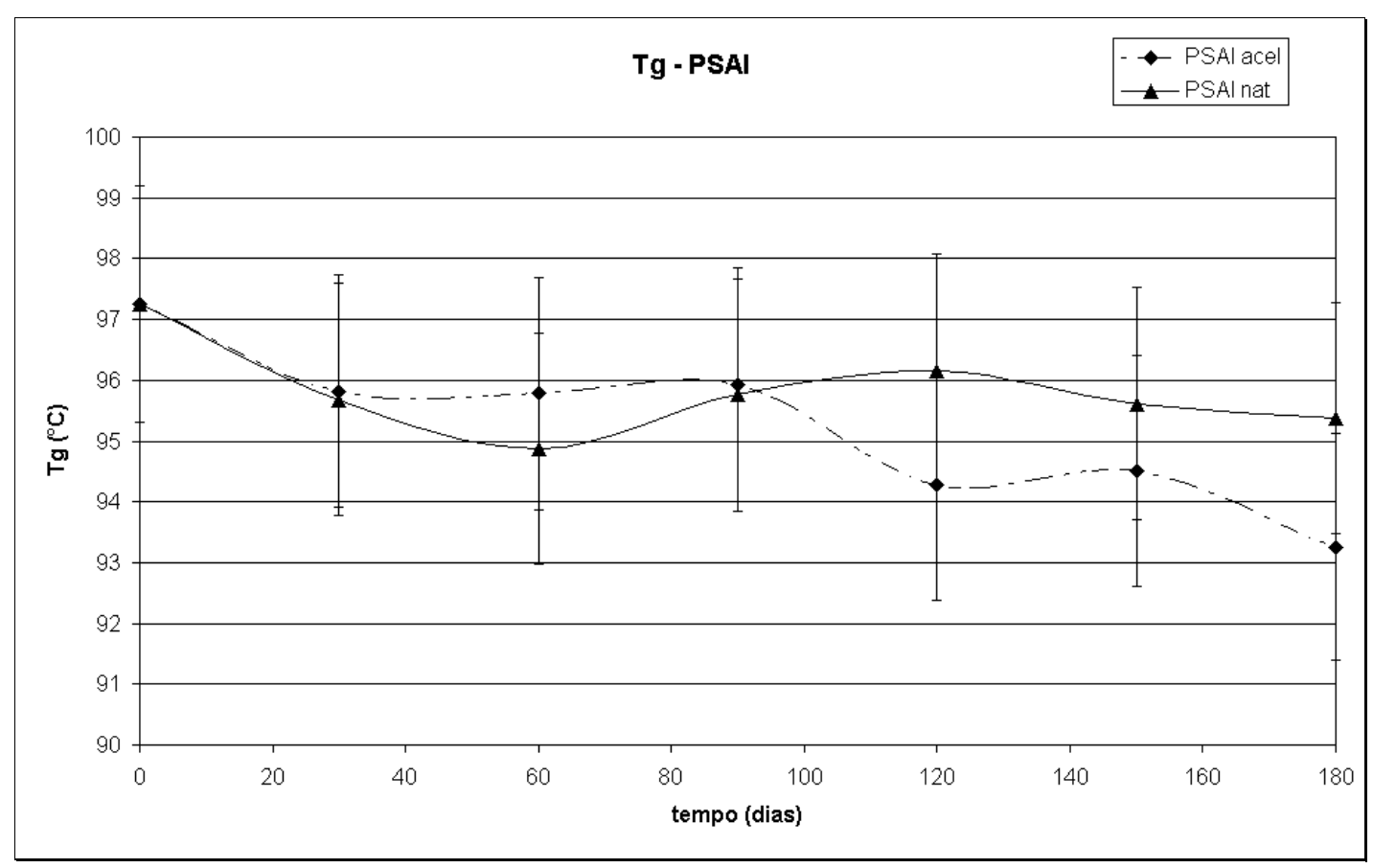

Figura 21: Temperaturas de transição vítrea de PSAI de acordo com o envelhecimento. Tempos do envelhecimento artificial estão multiplicados por um fator de aceleração de 2 . 


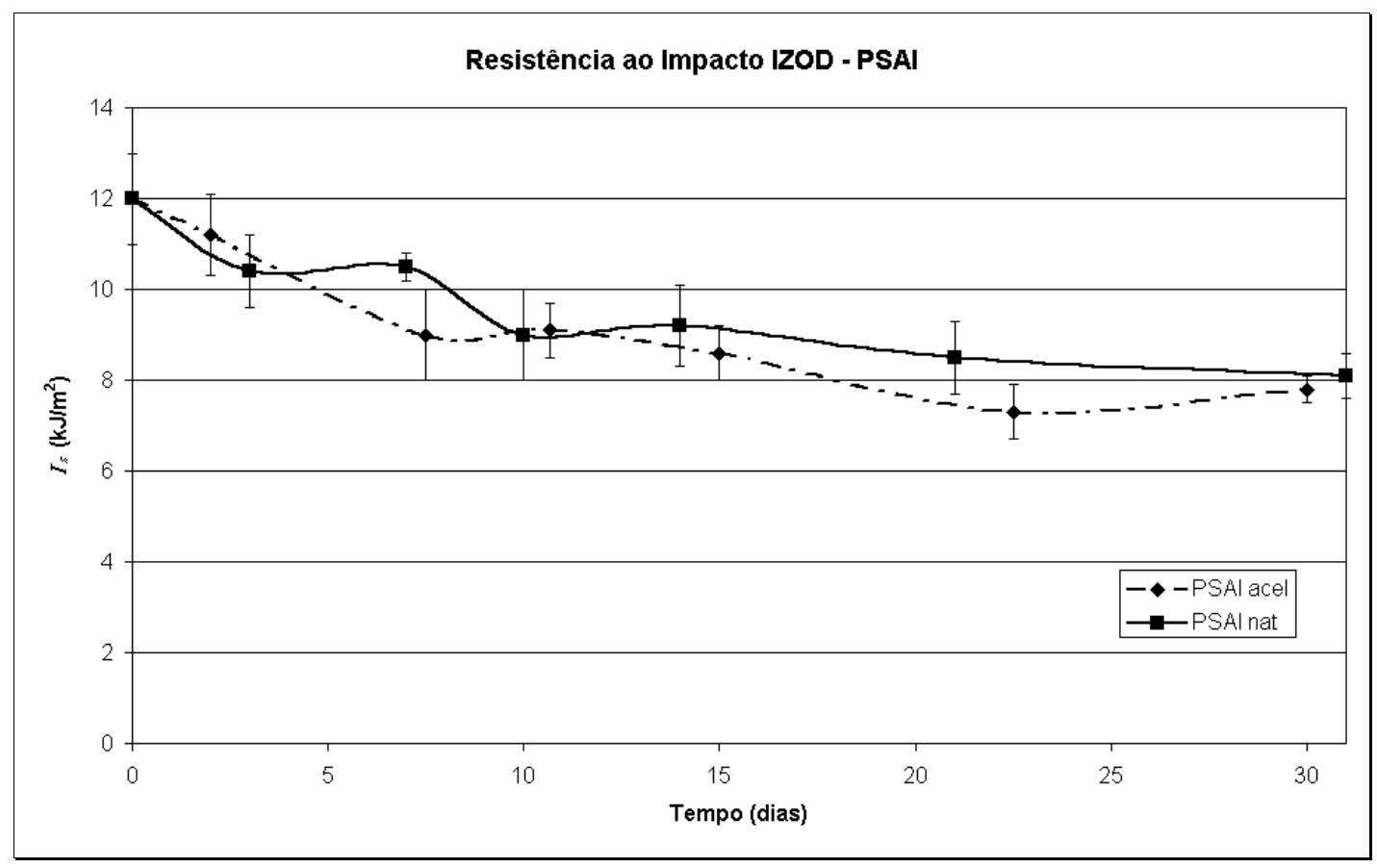

Figura 22: Resistências ao impacto IZOD de PSAI de acordo com o envelhecimento, convertidos para o sistema internacional. Tempos do envelhecimento artificial multiplicados por um fator de aceleração de 2.

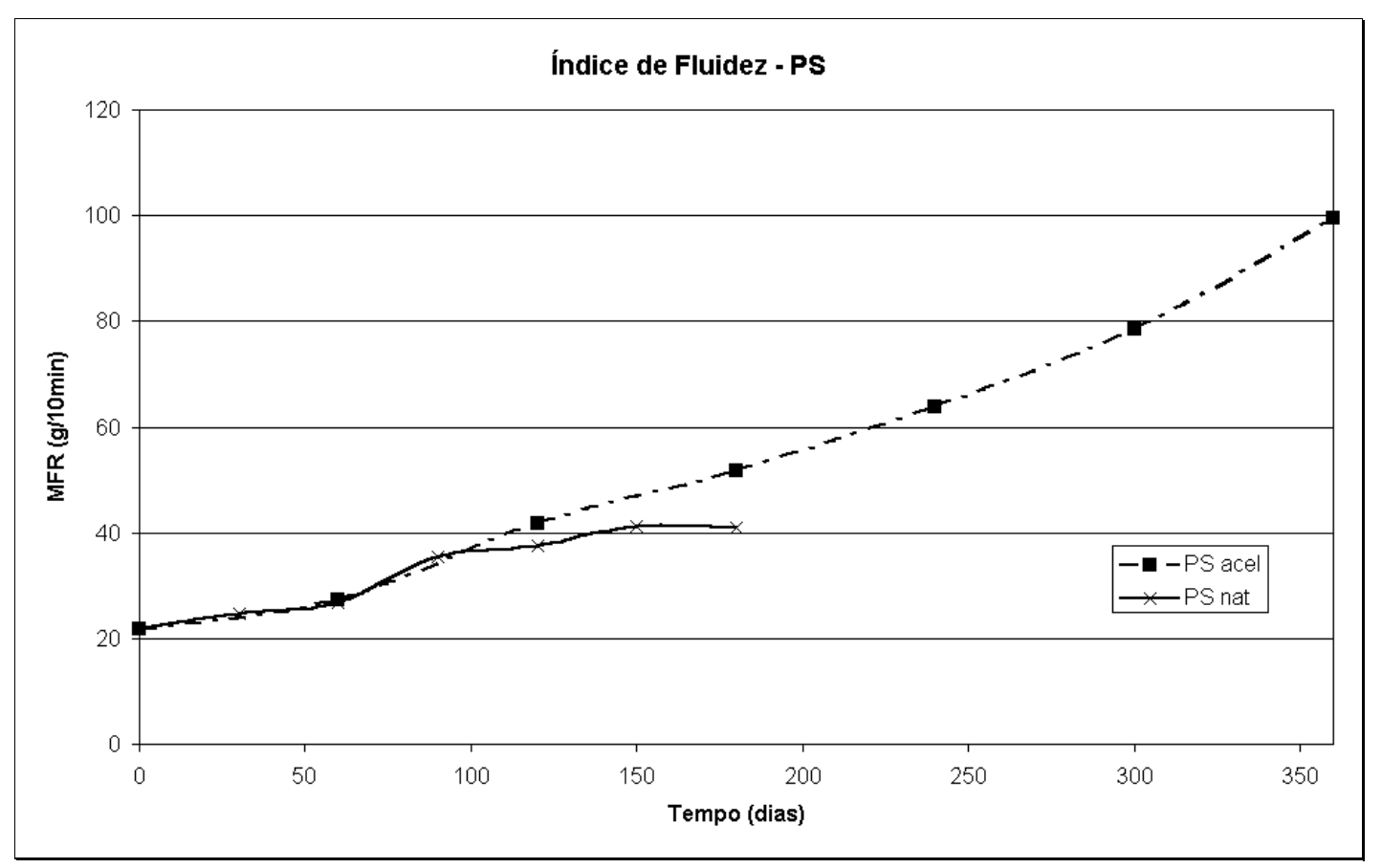

Figura 23: Índices de fluidez de PS de acordo com o envelhecimento. Tempos do envelhecimento artificial estão multiplicados por um fator de aceleração de 4. 


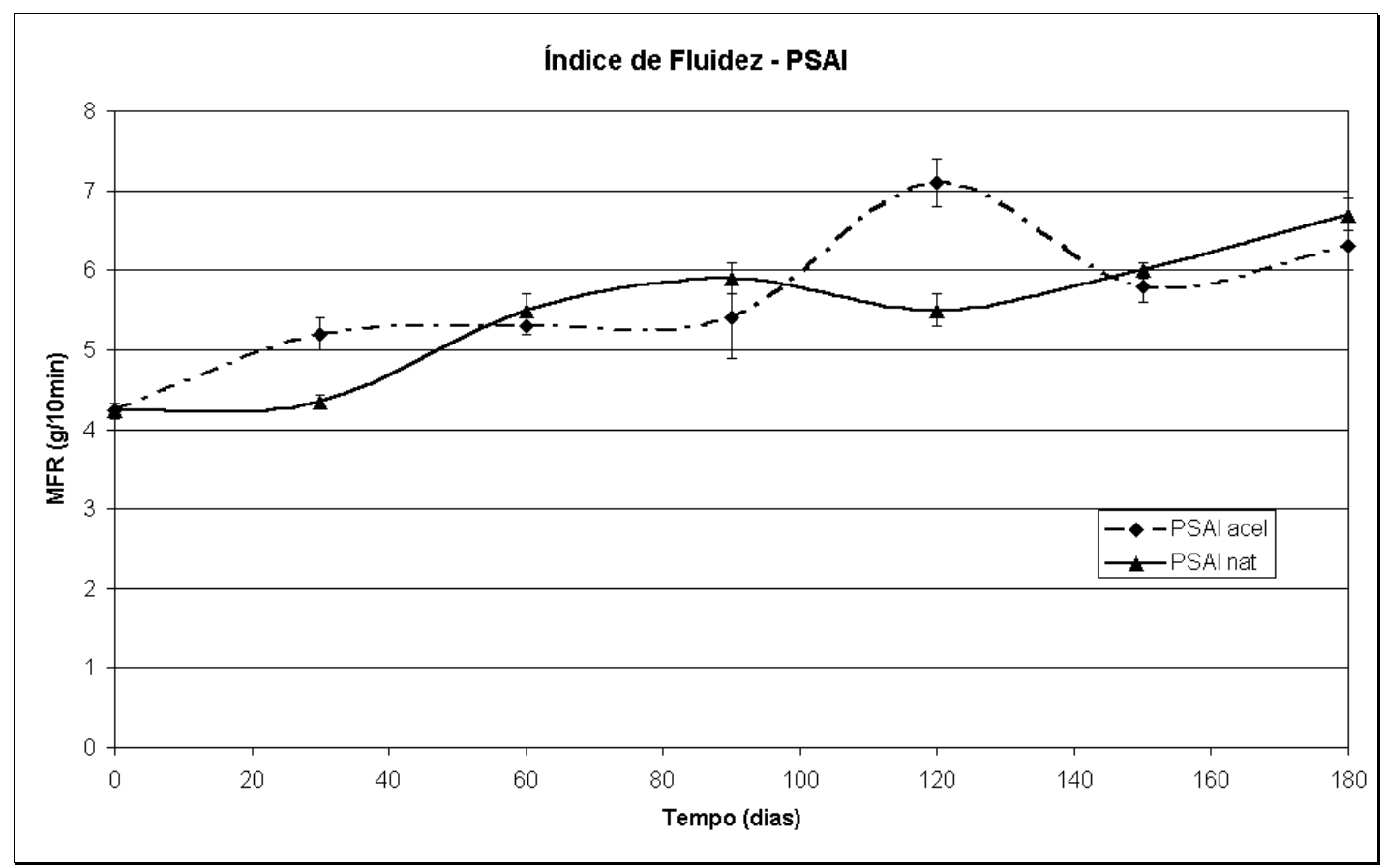

Figura 24: Índices de fluidez de PSAI de acordo com o envelhecimento. Tempos do envelhecimento artificial estão multiplicados por um fator de aceleração de 2 .

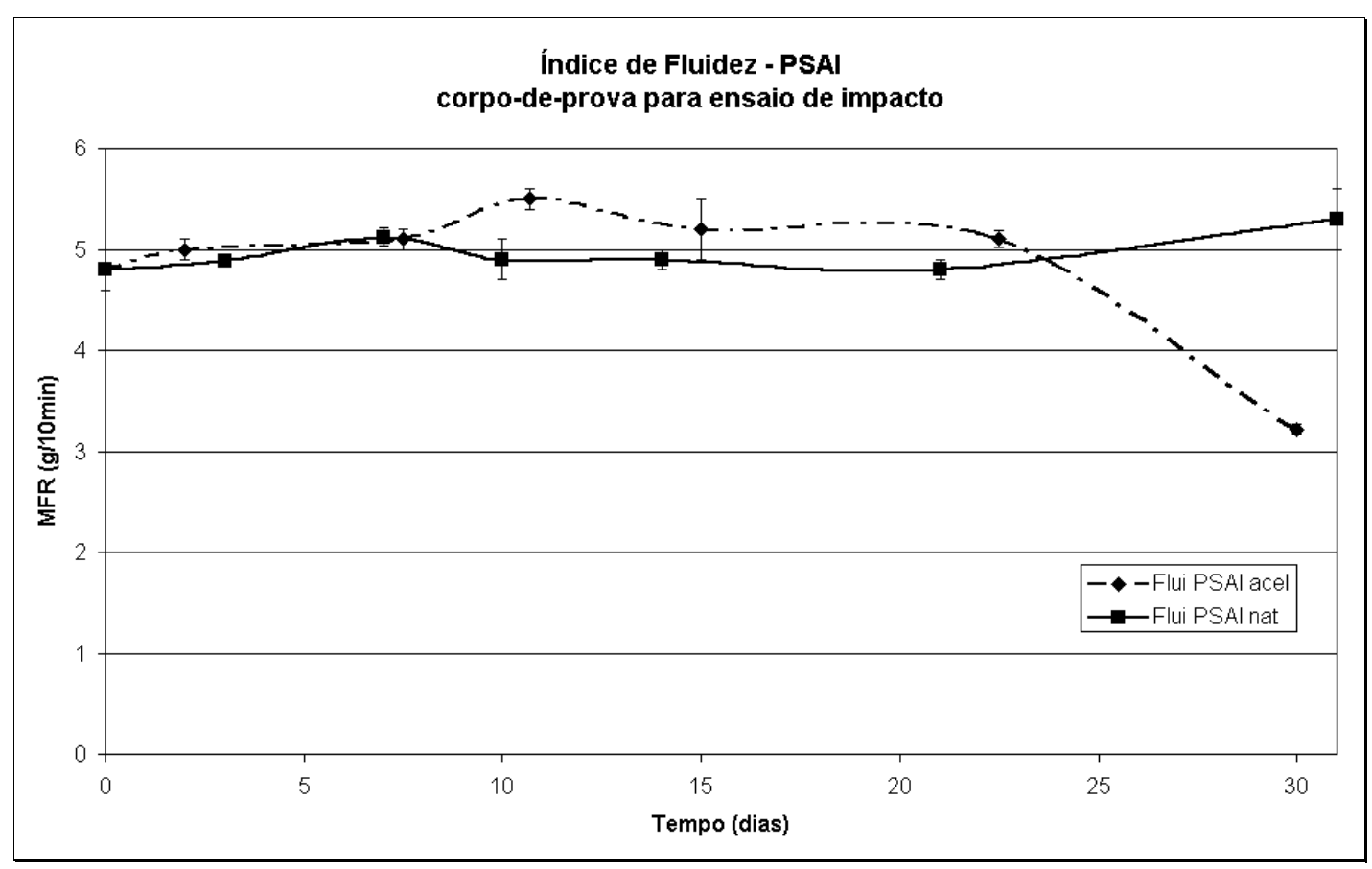

Figura 25: Índices de fluidez dos corpos de prova do ensaio de impacto de PSAI de acordo com o envelhecimento. Tempos do envelhecimento artificial estão multiplicados por um fator de aceleração de 2. 


\subsubsection{Aparência}

Avaliação qualitativa da aparência da seção transversal dos corpos de prova no último ponto de envelhecimento:

Face exposta

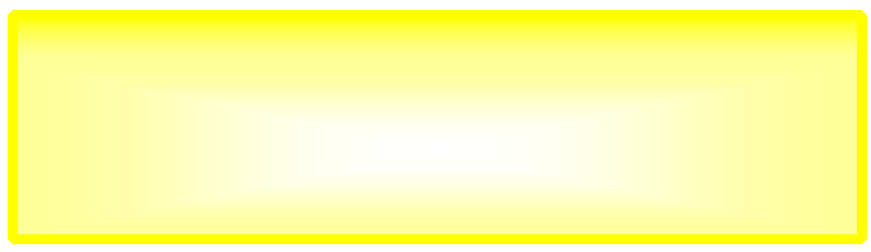

Figura 26: Esquema visual qualitativo do perfil de amarelecimento de PS

Face exposta

Figura 27: Esquema visual qualitativo do perfil de amarelecimento de PSAI 


\subsection{Discussão dos Resultados}

\subsubsection{Proposta de correlação}

Comparando-se os valores dos ensaios mecânicos de tração - Tabelas I a IV - e de impacto - Tabela VII - e do índice de fluidez - Tabelas VIII a X, nos envelhecimentos natural e artificial, foram propostos fatores de aceleração nos valores de tempo do envelhecimento artificial de 4 vezes para o PS e de 2 vezes para o PSAI que correlacionaram na maioria das curvas, o que se comprova observando as Figuras de 13 a 19 e de 22 a 25.

A correlação derivou da observação da Tabela I, em que a tensão na ruptura do PS chega em $15 \mathrm{MPa} 4$ vezes mais rápido no envelhecimento artificial que no envelhecimento natural e da Tabela III, em que os últimos pontos da tensão na ruptura do PSAI são similares.

Os demais ensaios foram utilizados para comprovar a correlação.

\section{Afinamento da correlação}

Para afinar este tipo de correlação, ensaios com duração de 1 ano ou mais poderiam ser realizados, com medições de mais propriedades, como caracterização química, como espectroscopias NIR e/ou FTIR, que foram vislumbradas para este trabalho, necessitando de técnicas apuradas, tais como microtomia, por exemplo. Medições de grau de amarelecimento também ajudariam a obter mais validações da correlação.

Os fatores de aceleração poderiam ser comprovados pela repetição do ensaio, inclusive chegando-se a valores mais precisos, com pelo menos uma casa decimal, por exemplo. 


\subsubsection{Ensaio de tração}

Os corpos de prova de PSAI originais, ou seja, sem sofrer foto-degradação, apresentaram comportamento dúctil, enquanto os demais corpos de prova revelaramse frágeis, tanto os corpos de prova de PS, reconhecidamente um polímero frágil, quanto os do próprio PSAI degradado já a partir do primeiro ponto dos envelhecimentos artificial e natural.

Os envelhecimentos natural e artificial do poliestireno tiveram uma boa correlação, conforme as Figuras 13 e 14, com um fator de aceleração de 4 vezes para o ensaio de tração.

É presumido que uma recuperação parcial da degradação ocorre quando a camada superficial torna-se tão fraca que não consegue transmitir tensão para o interior quando o material é tracionado (White; Turnbull, 1994).

As Figuras 15 e 16 mostram que a elongação do poliestireno de alto impacto tem uma alteração muito grande nos primeiros dias de degradação, tanto no envelhecimento natural quanto no artificial. O primeiro ponto (para o poliestireno de alto impacto sem sofrer a degradação) foi retirado no gráfico abaixo para aumentar a precisão de leitura dos demais pontos.

Como mostra a Figura 17, foi obtida boa correlação entre os envelhecimentos natural e artificial utilizando-se um fator de aceleração de 2 vezes para o ensaio de tração do poliestireno de alto impacto.

Os gráficos demonstram que a resistência à tração do poliestireno de alto impacto é menor que a do poliestireno sem modificações. Entretanto, sua tensão na ruptura ao longo dos envelhecimentos não é tão influenciada quanto a do poliestireno comum. Observando as curvas de elongação ao longo do tempo de degradação para os dois materiais, parece que a borracha degrada mais rapidamente que o poliestireno, como comentaram Xingzhou (1995) e Piton (1997), e forma uma camada protetora que impede a propagação dos efeitos dos raios ultravioleta.

Se a máquina na qual está sendo efetuado o ensaio de intemperismo artificial pára de funcionar por algum motivo, como falta de fornecimento de energia elétrica, pode ocorrer a difusão de substâncias reativas, como o oxigênio ou algum produto de reação da foto-oxidação. Isto pode explicar alguma eventual incoerência no ensaio de 
envelhecimento artificial, já que no procedimento de ensaio utilizado não prevê ciclos noturnos em sua programação.

Os resultados para o módulo de elasticidade (Módulo de Young) foram derivados das curvas de tensão e não demonstraram serem muito precisos, como observados nas Figuras 18 e 19. O uso de extensômetro nos ensaios de tração poderia garantir resultados mais precisos.

\subsubsection{Ensaio de calorimetria exploratória diferencial (DSC)}

Um conjunto de amostras retiradas da parte útil dos corpos de prova do ensaio de tração foi encaminhado para investigações de DSC no IPEN, resultando picos endotérmicos resultantes de relaxamento das tensões do corpo de prova, como mostrado nas Figuras 3 e 4.

Um pico de relaxação térmica aparece no ensaio logo após o indício de se ter ultrapassado a $T_{g}$, como um mínimo (endotérmico) após a inflexão da curva de fluxo de calor versus temperatura.

Então, foi decidido utilizar um conjunto de amostras retiradas das extremidades dos corpos de prova tracionados para eliminar a possibilidade de se ter tensões residuais do ensaio de tração, mas mesmo assim alguns picos de relaxação térmica foram observados, como mostra a Figura 3 nos dados da amostra "PS0720hAm14ext" em comparação com a "PS0720hAm14ext2aCorrida" e na Figura 4, da amostra "PS1080hAm24ext" comparada com "PS1080hAm24ext2aCorrida".

Os demais eventos que podem ter deixado tensões residuais são a injeção do material e os choques térmicos no envelhecimento artificial pela aspersão de água e no envelhecimento natural pelas chuvas.

Observando as Figuras 5 a 12, apenas no envelhecimento artificial acelerado é que houve indícios de tensões residuais, sugerindo que a aspersão de água no equipamento gera um choque térmico mais agressivo que a chuva no envelhecimento natural.

Então o próximo passo para conseguir boas curvas para o DSC foi fazer as segundas corridas de máquina para as amostras. 
Pela observação das Figuras 20 e 21, as temperaturas de transição vítrea não são muito influenciadas pela foto-degradação, comprovando o que se diz da dependência da $T_{g}$ quanto ao tamanho de cadeia para polímeros de alta massa molar. Segundo Fried (1995), sobre o efeito da Massa Molar na $T_{g}$, "a temperatura de transição vítrea aumenta com a massa molar para massas molares pequenas, mas chega em um ponto para massas molares moderadas, até que aumentos na massa molar influam muito pouco na $T_{g} . "$

Os valores estão exibidos com os mesmos fatores de aceleração dos ensaios mecânicos para se ter uma coerência de resultados, mas como não houve uma influência significativa das degradações nos valores de $T_{g}$, uma correlação não se faz necessária para este ensaio.

Podemos dizer então, que o PS e o PSAI tiveram uma boa estabilidade de sua propriedade térmica $T_{g}$ durante os ensaios de degradação natural e artificial.

\subsubsection{Ensaio de Impacto IZOD}

Como os resultados da elongação do PSAI variaram muito no primeiro mês, a banca de qualificação desta Dissertação sugeriu que se fizesse mais um ensaio retirando-se os corpos de prova em intervalos durante o primeiro mês apenas para o PSAI e que se fizesse o ensaio de impacto, pois é a característica principal do PSAI.

O ensaio de impacto utilizado foi do tipo IZOD com entalhe, pois uma investigação prévia do teste de impacto com alguns corpos de prova sem entalhe do PSAI original não chegaram ao rompimento

Como mostrado pela Figura 22, há uma tendência de diminuição da resistência ao impacto com a degradação e um fator de 2 vezes correlacionou bem os dados do envelhecimento natural e artificial do poliestireno de alto impacto. Mostra que a resistência ao impacto diminui em $30 \%$ no primeiro mês de envelhecimento. 


\subsubsection{Ensaio de índice de fluidez}

Pela análise das Figuras 23 e 24, o índice de fluidez teve a tendência a aumentar ao longo do tempo, o que demonstra claramente que ocorreram mecanismos de cisão de cadeia na degradação de ambos polímeros, principalmente no poliestireno comum, o que leva a conclusão que o polibutadieno protege o poliestireno.

Observando a Figura 25, os índices de fluidez para os corpos de prova para ensaio de resistência ao impacto quase não tiveram variações significativas para os 30 dias de envelhecimento.

O último ponto do envelhecimento artificial (360 h de máquina) para este tipo de corpo de prova não coincidiu com o valor deste mesmo tempo de envelhecimento para o corpo de prova para ensaio de resistência à tração, mostrando que das 270 horas de máquina até as $360 \mathrm{~h}$ deve ter havido um mecanismo de reticulação muito forte para este valor diminuir tanto assim.

\subsubsection{Aparência}

Comparando-se as Figuras 26 e 27 em termos qualitativos do amarelecimento da superfície em relação ao interior, observa-se que a camada superficial degradada do PSAI apresentou-se como uma proteção para o restante do material. 


\section{Conclusão}

A comparação entre os envelhecimentos natural e artificial dos polímeros resultou em boas correlações levando-se em conta suas propriedades mecânicas, tais como resistência à tração, elongação em tração, resistência ao impacto e índice de fluidez, com um fator de aceleração de 4 vezes para o poliestireno e com um fator de 2 vezes para o poliestireno de alto impacto.

Esta avaliação valida o ensaio em equipamentos de intemperismo artificial para o objetivo de previsão de falhas mecânicas, mas apesar de se ter conseguido estas correlações, não se pode afirmar que em qualquer ensaio de intemperismo que se fizer com estes materiais os fatores de aceleração serão os mesmos, pois os testes foram feitos em uma dada época do ano, com variações climáticas que não se repetirão de igual maneira.

As $T_{g}$ 's do PS e do PSAI não tiveram variações significativas para ambos envelhecimentos (natural ou acelerado), ou, se houve, o erro do procedimento não permitiu chegar a esta conclusão. Não puderam portanto ser utilizadas para correlacionar os dois tipos de envelhecimento, mas podemos dizer que o PS e o PSAI tiveram boa estabilidade da propriedade térmica $T_{g}$ durante os ensaios.

Quanto à adição de borracha no poliestireno, o ensaio mostrou que além de modificar suas propriedades mecânicas, a suscetibilidade à foto-degradação é extremamente alterada. O polibutadieno parece degradar rapidamente no primeiro mês, resultando em redução drástica na elongação em tração e de redução intensa na resistência ao impacto durante os primeiros 15 dias de envelhecimento. Depois desta degradação intensa, as duas propriedades dependentes das condições superficiais (elongação em tração e resistência ao impacto) do poliestireno de alto impacto diminuem muito pouco.

As demais propriedades (resistência à tração e índice de fluidez) modificaram de forma menos drástica que no poliestireno comum, o que leva a conclusão que a borracha, apesar de degradar muito mais rapidamente que o poliestireno, protege o poliestireno da degradação, justamente por absorver a radiação mais facilmente. 
É presumido que uma camada superficial fique tão degradada que não consiga transmitir tensões para o interior do material.

Pressupõe-se que a camada superficial do PSAI, que teve sua porção de borracha degradada, protege a camada interna do polímero, pois a mesma absorve a radiação ultravioleta incidente, impedindo a penetração dos raios no restante do material.

Os corpos de prova apresentaram toda a superfície exposta mais degradada que seus interiores, tanto na face exposta à luz, bem como nas faces não expostas diretamente (luz dispersa), o que confirma as proposições de Delprat e Gardette (1993) , O’Donnell e White (1994), White e Turnbull (1994), George (1995) e Rabello (2000) de que a difusão de oxigênio é o fator que rege a cinética da reação de foto-oxidação. $\mathrm{O}$ índice de fluidez comprovou a tendência de diminuição da massa molar ao longo da degradação dos polímeros, em maior intensidade para o PS que para o PSAI.

Será que se pode concluir que além da adição de borracha na estrutura do poliestireno modificar várias propriedades mecânicas do poliestireno, tais como resistência ao impacto e alongamento, pode servir como um aditivo de proteção quanto à degradação foto-oxidativa? Talvez utilizando-se apenas uma camada de material adicionado de borracha na parte superficial do material interno, ou então desenvolvendo um produto protetor de superfície, ou inclusive utilizando-se pigmentos para que o produto mantenha a boa aparência. Algumas investigações nesta área poderiam levar a novos desenvolvimentos em proteção de polímeros.

Podemos afirmar que para produtos de poliestireno que exijam exposições solares, o PSAI é bem mais indicado que o PS comum.

A utilização de envelhecimento artificial acelerado para produtos de poliestireno pode ajudar a prever as modificações de propriedades dos mesmos quando expostos a radiações ultravioleta, com degradações foto-oxidativas. 
Anexo A - Registro dos ensaios de tração de PS e de PSAI

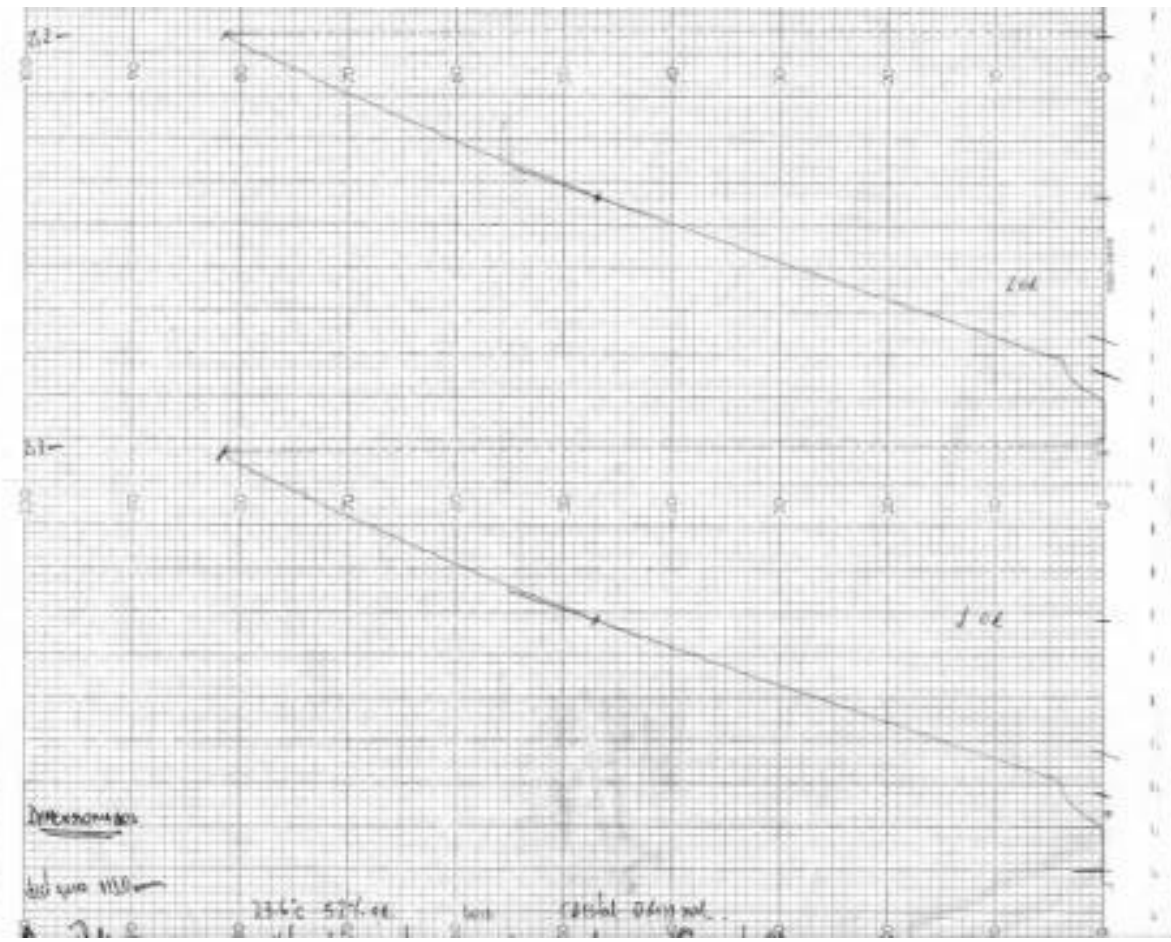

Figura 28: Ensaio de tração de PS original

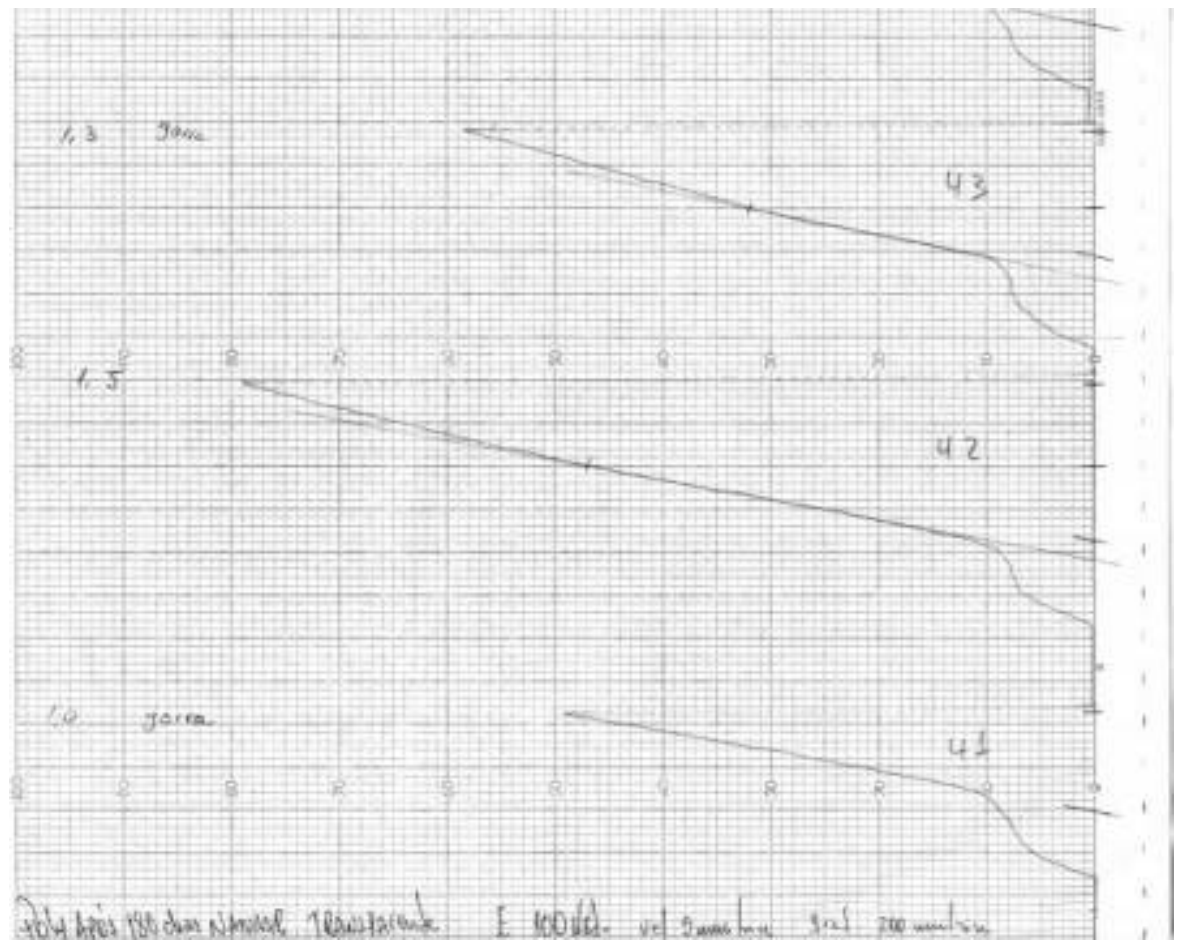

Figura 29: Ensaio de tração de PS após 180 dias de envelhecimento natural 


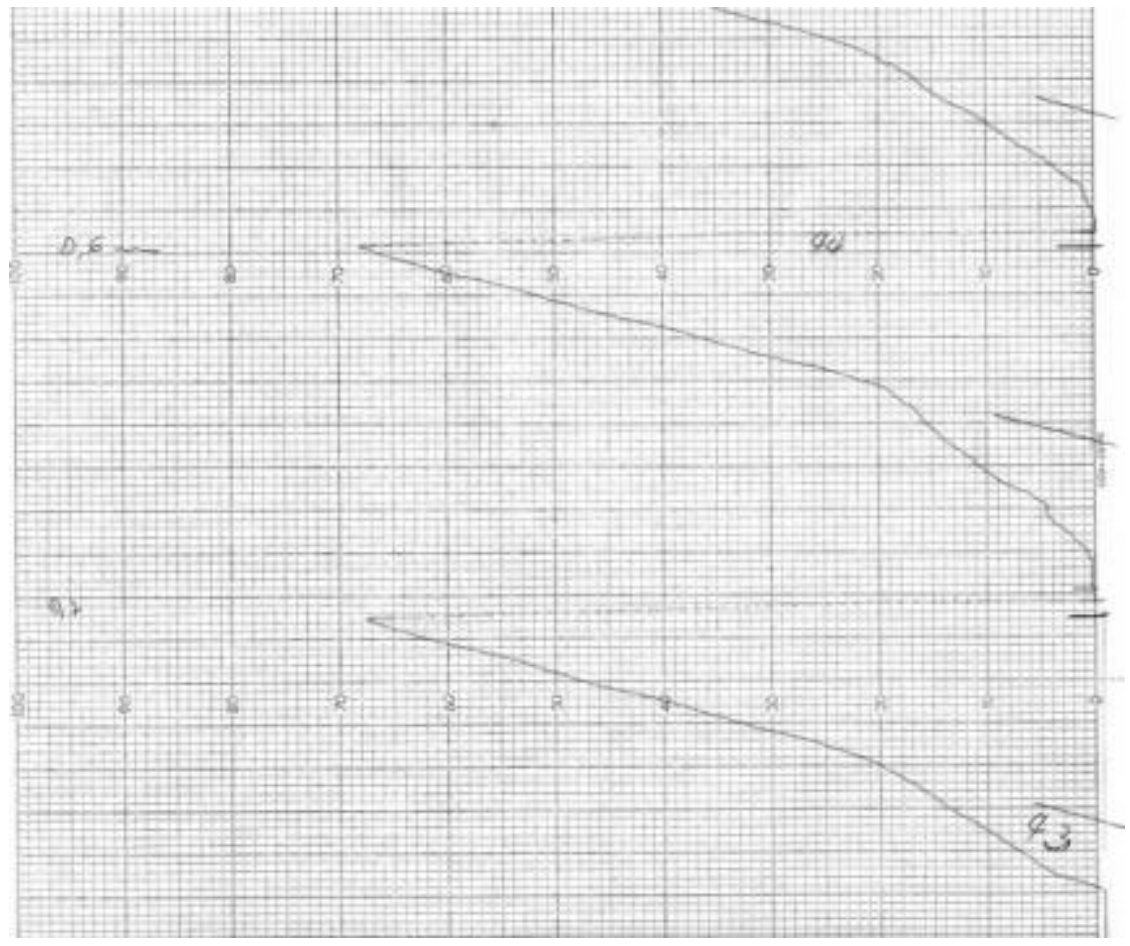

Figura 30: Ensaio de tração de PS após 2160 horas de envelhecimento artificial

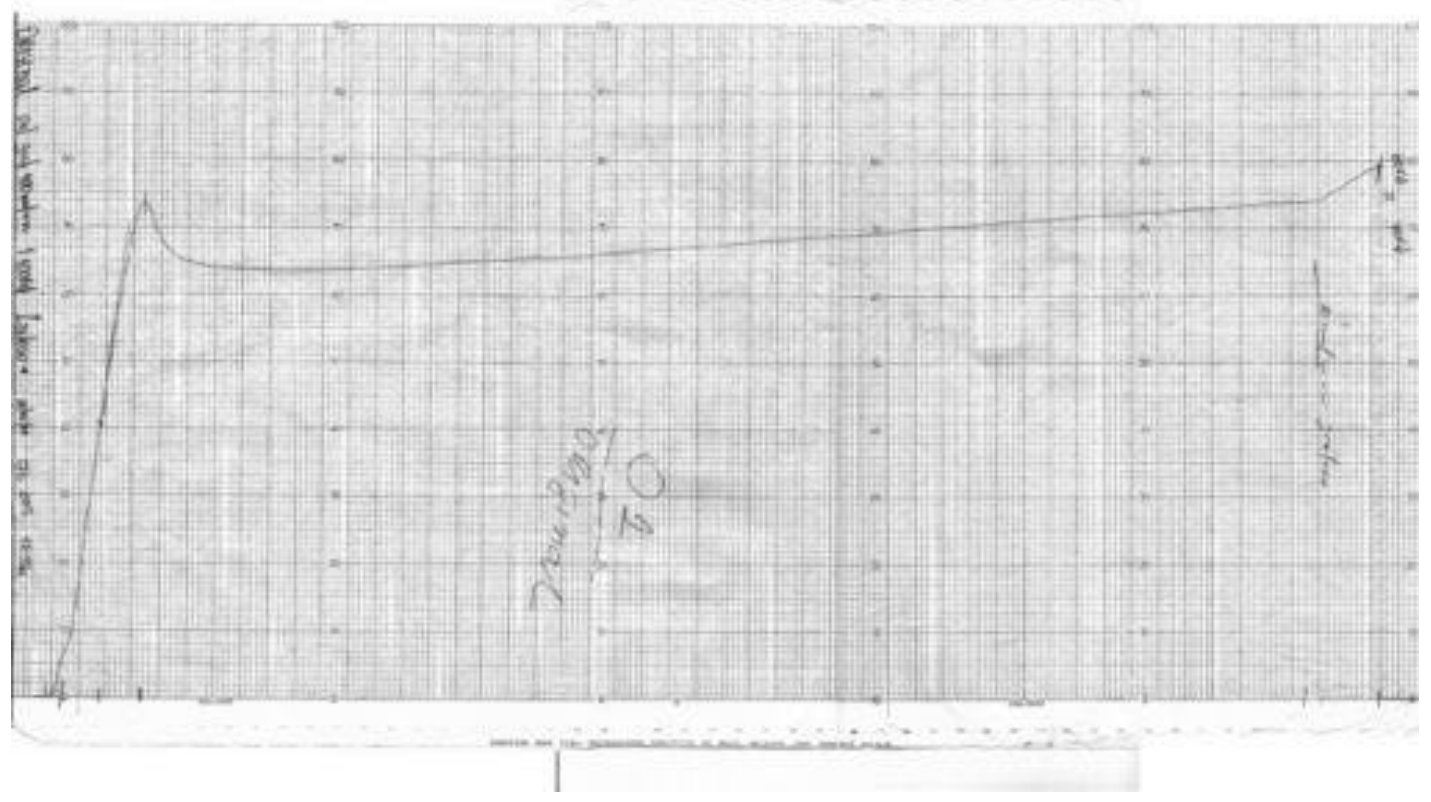

Figura 31: Ensaio de tração de PSAI original 


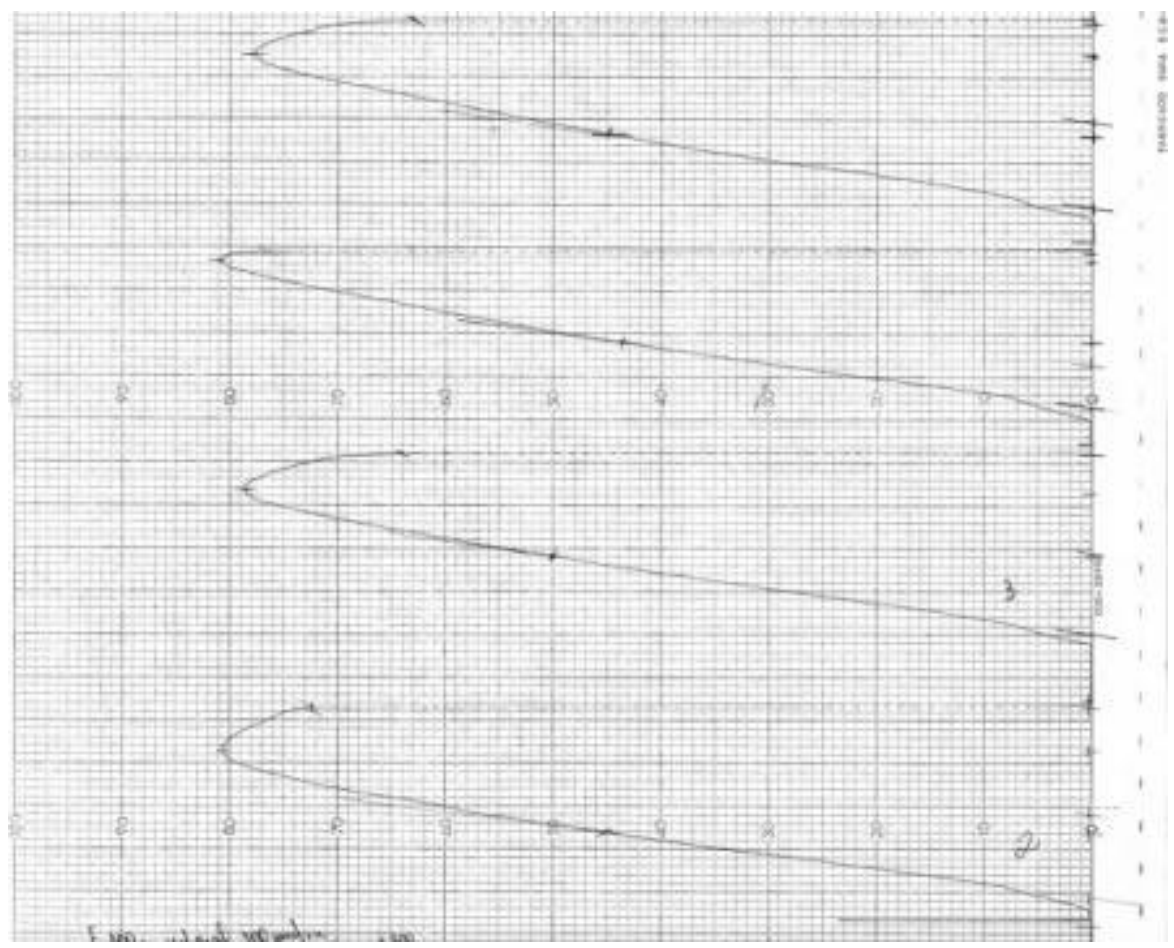

Figura 32: Ensaio de tração de PSAI envelhecido 30 dias

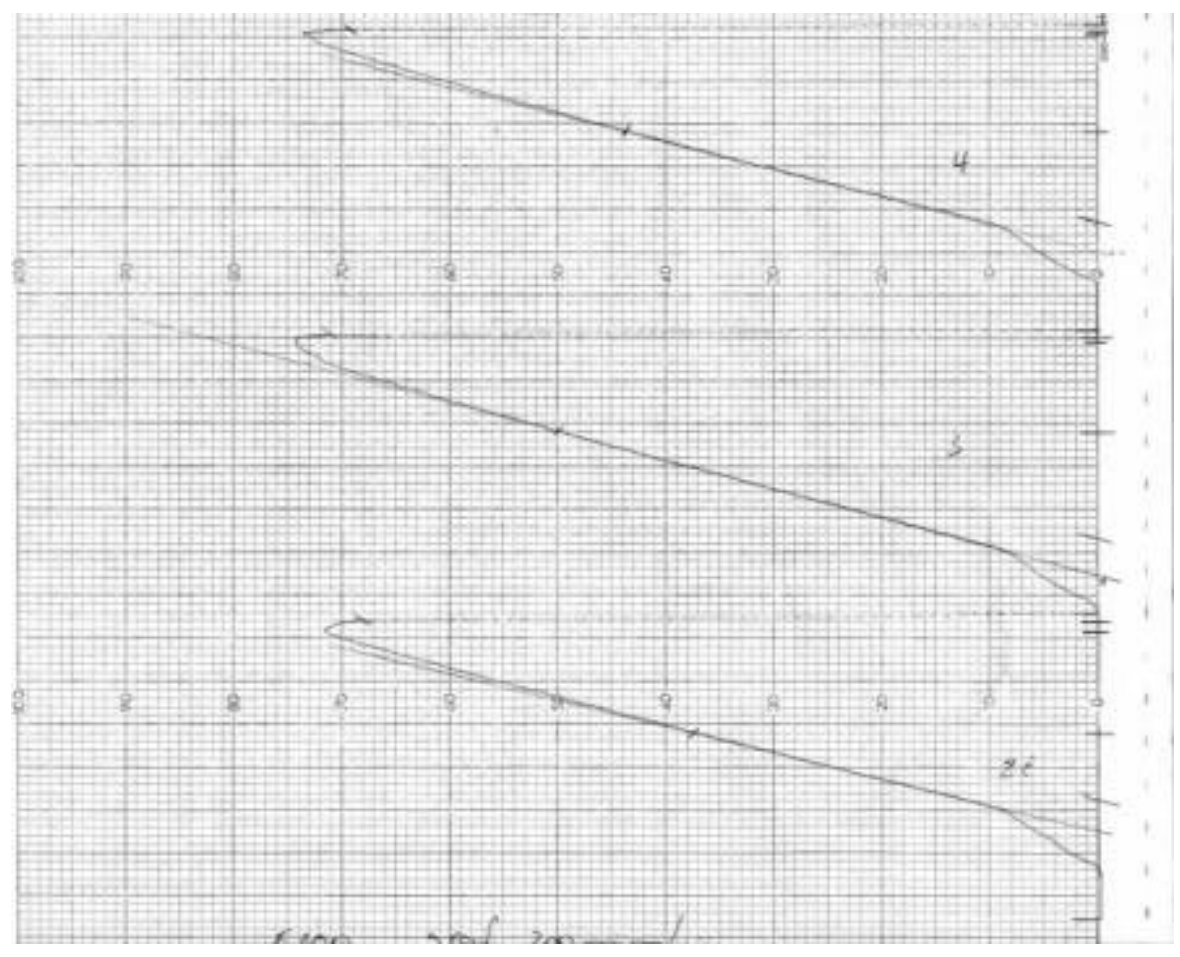

Figura 33: Ensaio de tração de PSAI envelhecido 360 horas 


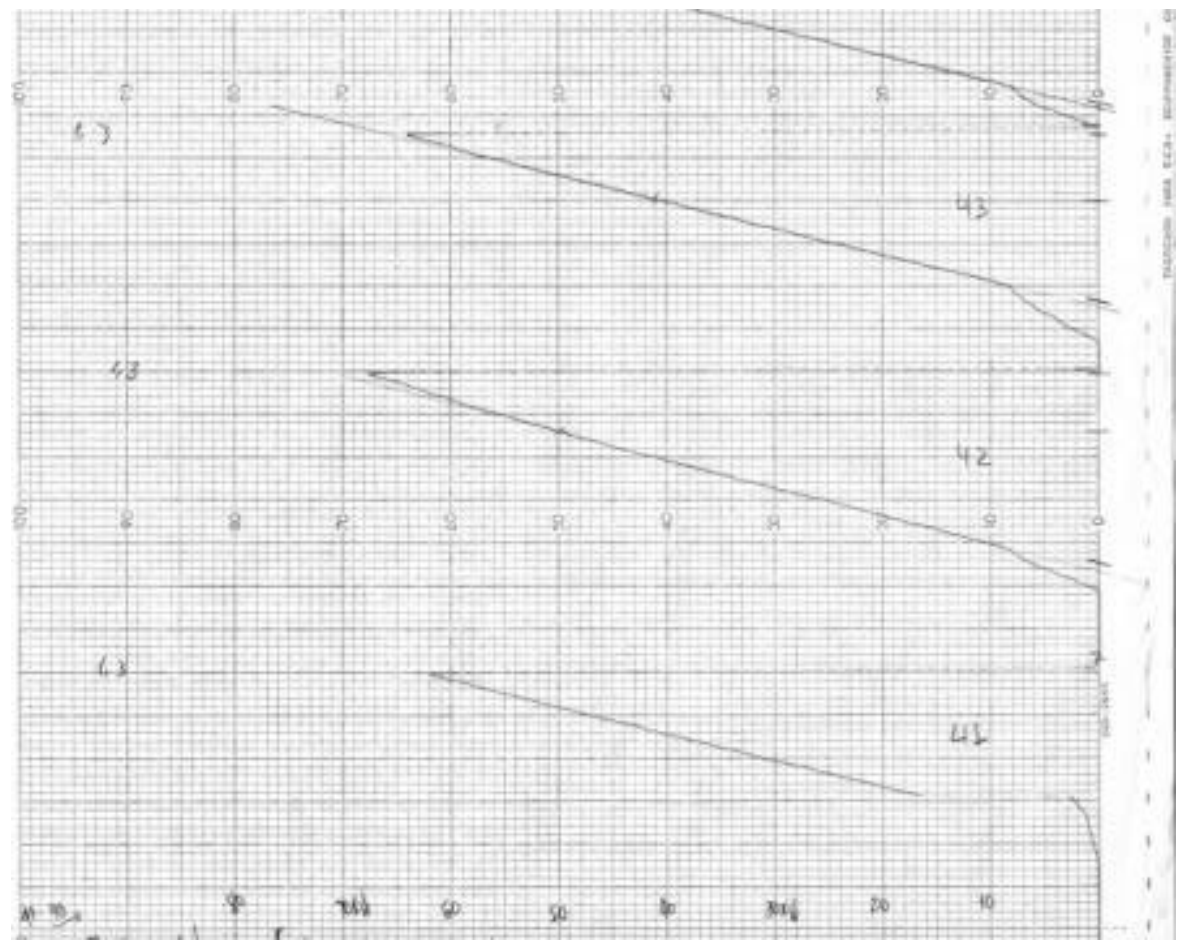

Figura 34: Ensaio de tração de PSAI envelhecido 180 dias

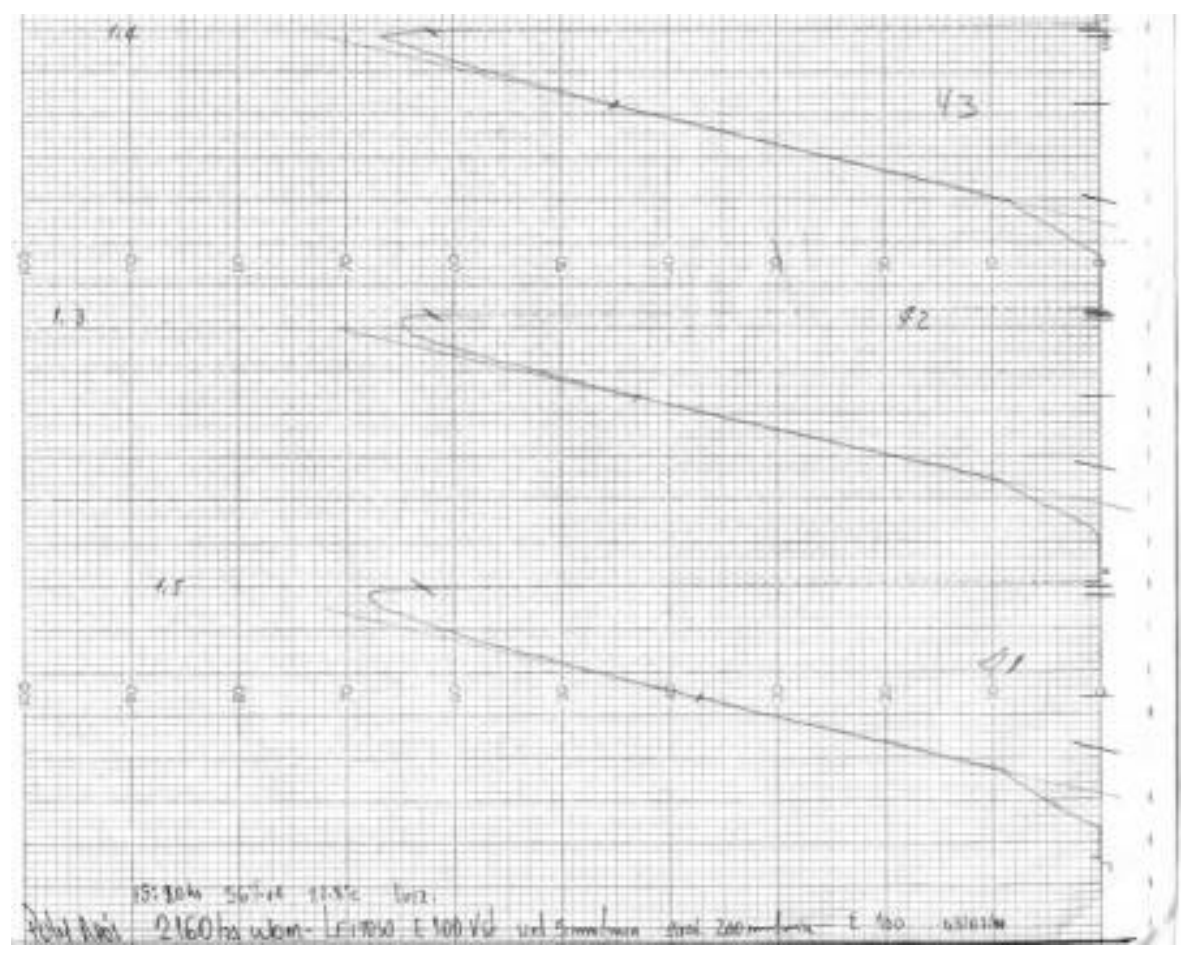

Figura 35: Ensaio de tração de PSAI envelhecido 2160 horas 
Anexo B - Registro dos corpos de prova dos ensaios de tração de PS e de PSAI

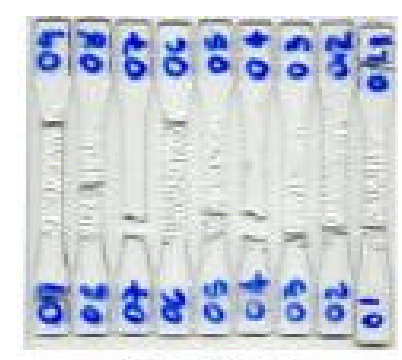

PS original
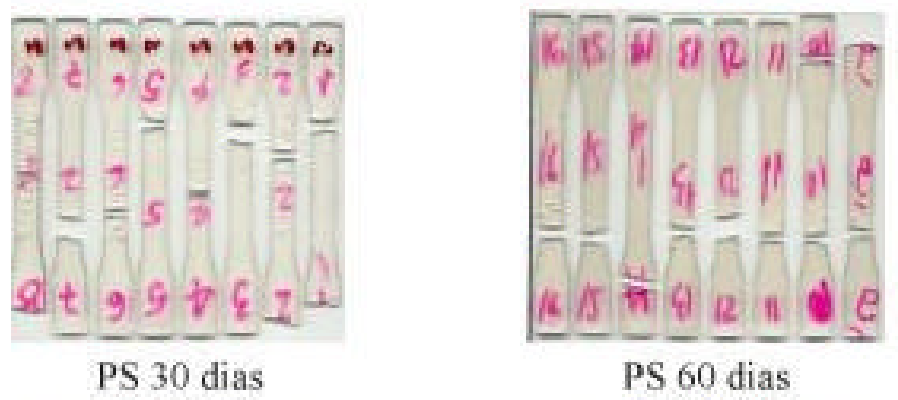

PS 60 dias

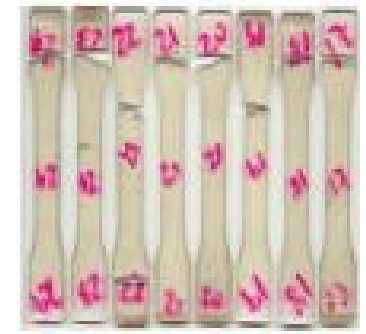

PS 90 dias
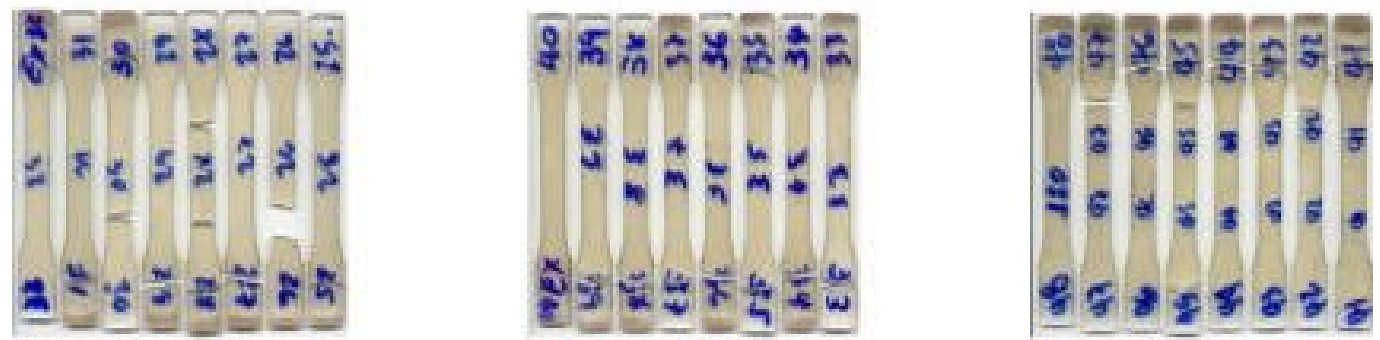

PS 120 dias

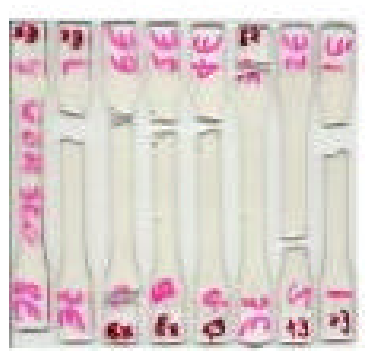

PS 150 dias

PS 180 dias
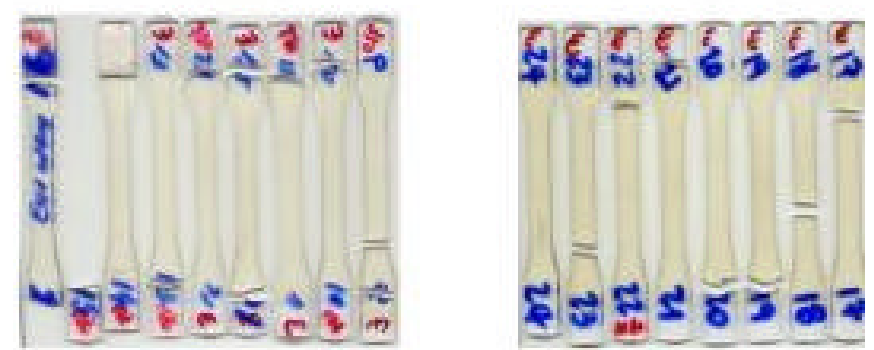

PS 720 horas

PS 1080 horas

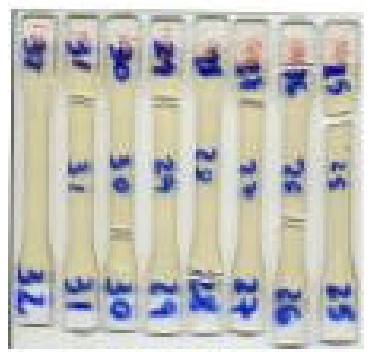

PS 1440 horas

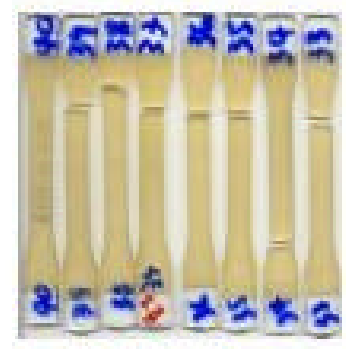

PS 1800 horas

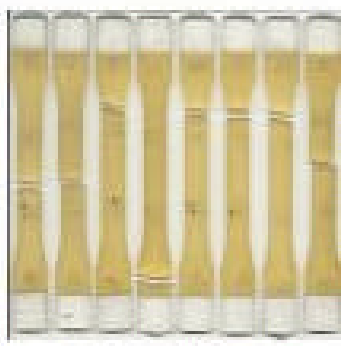

PS 2160 horas

Figura 36: Corpos de prova de tração de PS originais e envelhecidos após a ruptura 

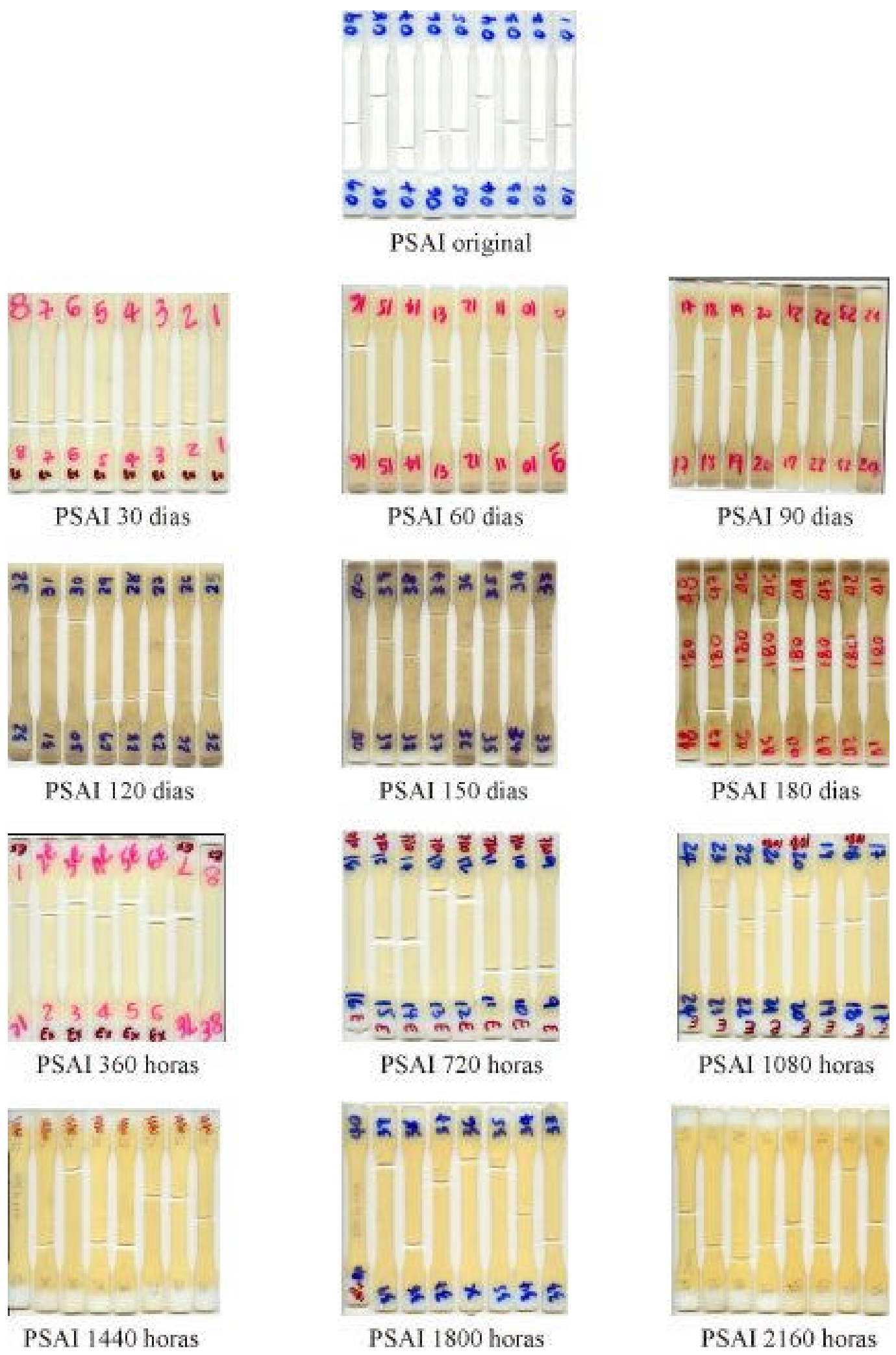

Figura 37: Corpos de prova de tração de PSAI originais e envelhecidos após a ruptura 


\section{Lista de Referências}

ALLAN, D.S.; MAECKER, N.L.; PRIDDY, D.B.; SCHROCK, N.J. Modeling photodegradation in transparent polymers. Polymer Preprints, Chicago, v.34, n.2, p.201-202, ago. 1993.

ANDRADY, A.L.; HAMID, S.H.; HU, X.; TORIKAI, A. Effects of increased solar ultraviolet radiation on materials. Journal of Photochemistry and Photobiology B: Biology, v.46, p.96-103, 1998.

ARAÚJO, S.C.; KAWANO, Y.; WIEBECK, H.; BATISTA, M.S. Identificação de poliamida 6 reciclada utilizando espectroscopia no infravermelho próximo. In: CONGRESSO BRASILEIRO de POLÍMEROS, 5, Águas de Lindóia, 1999. Anais. São Paulo, ABPol, 1999. p.565-566

ASALETHA, R.; KUMARAN, M.G.; THOMAS, S. Thermal behaviour of natural rubber/polystyrene blends: thermogravimetric and differential scanning calorimetric analysis. Polymer Degradation and Stability, v.61, p.431-439, 1998.

BAKER, T.L.; MARIENFELD, M.L. Correlation of outdoor exposure to xenon-arc weatherometer exposure. In: GEOSYNTHETICS '95 CONFERENCE, Nashville, 1995. Proceedings. St. Paul, Industrial Fabrica Association International, 1995. v.3, p.829-839

BERNA, J.M.L. El envejecimiento ambiental de los materiales polimericos. Caracteristicas para su evaluacion y metodos de ensayo - Parte 1. Revista de Plásticos Modernos, v.61, n.415, p.125-129, 1991. 
CASSIDY, O.E.; ROWLEY, G.; FLETCHER, I.W.; DAVIES, S.F; BRIGGS, D. Surface modification and electrostatic charge of polystyrene particles. International Journal of Pharmaceutics, v.182, p.199-211, 1999.

CORAZZA FILHO, E. C. Termoplásticos: os materiais e suas transformações. 4. ed. São Paulo, s.n., 1995.

CRAWFORD, R. J. Plastics engineering. Cingapura, Pergamon Press, 1989.

DELPRAT, P.; GARDETTE, J-L. Analysis of photooxidation of polymer materials by photoacoustic Fourier transform infra-red spectroscopy. Polymer, v.34, n.5, p.933-937, 1993.

FAUCITANO, A.; BUTtAFAVA, A.; CAMINO, G.; GRECI, L. Photo-oxidation and stabilization of polymers. Trends in Polymer Science, v.4, n.3, p.92-98, 1996.

FRIED, J.R. Polymer Science and Technology. New Jersey, Prentice Hall PTR, 1995

GEORGE, G.A. Weathering of polymers. Materials Forum, v.19, p.145-161, 1995.

GIJSMAN, P. Oxygen uptake as a method to compare the UV-degradation chemistry in na accelerated (Xenon) test and outdoors. Polymer Preprints, Chicago, v.34, n.2, p.183-184, 1993.

KACZMAREK, H. Changes to polymer morphology caused by u.v. radiation: 1 . Surface damage. Polymer Papers, v.37, n.2, p.189-194, 1996. 
KONSTANTINOVA, T.; BOGDANOVA, A.; STANIMIROV, S.; KONSTANTINOV, H. Synthesis and application of UV stabilizers for polymeric materials based on triazinylaminobenzotriazole. Polymer Degradation and Stability, v.43, p.187-193, 1994.

LUNARDI, G. Polímero dopado passa de isolante a condutor. Química e Derivados, n 249, p.10-18, dez. 1987.

MAILHOT, B.; GARDETTE, J.-L. Polystyrene photooxidation. 1. Identification of the IR-absorbing photoproducts formed at short and long wavelengths. Macromolecules, v.25, p.4119-4126, 1992a.

MAILHOT, B.; GARDETTE, J.-L. Polystyrene photooxidation. 2. A pseudo wavelength effect. Macromolecules, v.25, p.4127-4133, 1992b.

MAILHOT, B.; JARROUX, N; GARDETTE, J-L. Comparative analysis of the photo-oxidation of polystyrene and poly( $\alpha$-methylstyrene). Polymer Degradation and Stability, v.68, p.321-326, 2000.

MANO, E.B. Polímeros como materiais de engenharia. São Paulo, Edgard Blücher, 1991.

MELO, C.P. Polímeros condutores. Ciência Hoje, v.6, n.36, p.39-47, out. 1987.

O’DONNELL, B.; WHITE, J.R. Stress-accelerated photo-oxidation in polystyrene. Polymer Preprints, Chicago, v.34, n.2, p.137-138, 1993.

O'DONNELL, B.; WHITE, J.R. Photo-oxidation of polystyrene under load. Journal of Materials Science, v.29, p.3955-3063, 1994. 
O’DONNELL, B.; WHITE, J.R.; HOLLDING, S.R. Molecular weight Measurement in weathered polymers. Journal of Applied Polymer Science, v.52, p.1607-1618, 1994.

PITON, M.; RIVATON, A. Photo-oxidation of ABS at long wavelenghts $(\lambda>300$ nm). Polymer Degradation and Stability, v.55, p.147-157, 1997.

PITTOLO, M.; BURFORD, R.P. Rubber-crumb modified polystyrene: Part 1. Tensile properties. Journal of Materials Science, v.21, p.1769-1774, 1986.

RABELlO, M. Aditivação de polímeros. São Paulo, Artliber, 2000.

SALMAN, S.R. Photochemical degradation of recycled high-impact polystyrene. Polymer-Plastics Technology and Engineering, v.32, p.115-122, 1993.

SANCHEZ, E.M.S; FELISBERTI, M.I. Degradação fotooxidativa do ASA. In: CONGRESSO BRASILEIRO DE POLÍMEROS, 5, Águas de Lindóia. Anais. São Paulo, ABPol, 1999. p.465-469

SANCHEZ, E.M.S.; FERREIRA, M.C.; FELISBERTI, M.I. Avaliação da degradação térmica e fotooxidativa do ABS automotivo para fins de reciclagem. In: CONGRESSO BRASILEIRO DE POLÍMEROS, 5, Águas de Lindóia. Anais. São Paulo, ABPol, 1999. p.1565-1571

SEARLE, N.D. Weathering. In: ENCYCLOPEDIA of Polymer Science and Engineering. New York, Wiley-Interscience, 1989. v.17, p. 796-827

SERIZAWA, T.; KAMIMURA, S; AKASHI, M Electrostatic adsorption of polystyrene particles with different surface charges onto the surface of an ultrathin polymer film. Colloids and Surfaces A: physicochemical and engineering aspects, v.164, p.237-245, 2000. 
SHYICHUK, A.V.; WHITE, J.R. Analysis of chain-scission and crosslinking rates in the photo-oxidation of polystyrene. Journal of Applied Polymer Science, v.77, p.3015-3023, 2000.

STEVENS, T. Polymers weather in good form: weatherable styrenic polymers and thermoforming combine for fabrication of large structures that must survive outdoors. Materials Engineering, v.109, n.11, p.8-9, 1992.

SUSSMAN, A. Guia para o planeta terra do Dr. Art. São Paulo, Cultrix, 2000.

THERMOFIL. Flame retardant HIPS. Plastics Engineering, v.47, p.45, dec. 1991.

TORIKAI, A. Photodegradation of polystyrene. In: HANDBOOK of polymer science and technology. New York, M. Dekker, v.2, p.605-624, 1989.

TORIKAI, A.; KATO, H.; FUEKI, K; SUZIKI, Y.; OKISAKI, F. Photodegradation of polymer materials containing flame-cut agents. Journal of Applied Polymer Science, v.50, p. 2185-2190, 1993.

TRINH, D.V.; LINTON, R.C.; VAUGHN, J.A.; FINCKENOR, M.M.; VAN DE MARK, M.R. Solar simulation photodegradation of polystyrene: phthalocyanine pigments as inhibitor of the photodegradation process. Polymer Degradation and Stability, v.46, p.325-331, 1994.

WEIR, N.A. \& WHITING, K. Initial steps in the photolysis and photooxidation of polystyrene. European Polymer Journal, v.25, n.3, p.291-295, 1989.

WHITE, J.R.; TURNBULL A. Review - weathering of polymers: mechanisms of degradation and stabilization, testing strategies and modeling. Journal of Materials Science, v.29, p.584-613, fev. 1994. 
XINGZHOU, H.; ZUBO, L. Wavelength sensitivity of photooxidation of styrenebutadiene-styrene copolymer. Polymer Degradation and Stability, v.48, p.99-102, 1995.

ZWEIFEIL, H. Degradation of polymers by photooxidation. Chimia, v.47, p.390$395,1993$. 